\title{
OXY-COMBUSTION BURNER AND INTEGRATED POLLUTANT REMOVAL RESEARCH AND DEVELOPMENT TEST FACILITY
}

Final Report - Non Confidential October 2006 - September 2012

\author{
Principle Investigator \\ Mark K. Schoenfield \\ Co-Authors \\ Jupiter Oxygen Project Team: Manny Menendez \\ NETL Project Team: Thomas Ochs, Rigel Woodside, Danylo \\ Oryshchyn \\ December 2012 \\ (revised) \\ DE-FC26-06NT42811 \\ Jupiter Oxygen Corporation \\ 4825 N. Scott Street Suite 200 \\ Schiller Park, IL 60176 \\ National Energy Technology Laboratory \\ 1450 Queen Avenue SW \\ Albany, OR 97321-2198
}




\section{DISCLAIMER}

This report was prepared as an account of work sponsored by an agency of the United States Government. Neither the United States Government nor any agency thereof, nor any of their employees, makes any warranty, express or implied, or assumes any legal liability or responsibility for the accuracy, completeness, or usefulness of any information, apparatus, product, or process disclosed, or represents that its use would not infringe privately owned rights. Reference herein to any specific commercial product, process, or service by trade name, trademark, manufacturer, or otherwise does not necessarily constitute or imply its endorsement, recommendation, or favoring by the United States Government or any agency thereof. The views- and opinions of authors expressed herein do not necessarily state or reflect those of the United States Government or any agency thereof. 


\section{ABSTRACT}

A high flame temperature oxy-combustion test facility consisting of a $5 \mathrm{MWe}$ equivalent test boiler facility and $20 \mathrm{KWe}$ equivalent IPR $\AA$ was constructed at the Hammond, Indiana manufacturing site. The test facility was operated natural gas and coal fuels and parametric studies were performed to determine the optimal performance conditions and generated the necessary technical data required to demonstrate the technologies are viable for technical and economic scale-up. Flame temperatures between 4930-6120F were achieved with high flame temperature oxy-natural gas combustion depending on whether additional recirculated flue gases are added to balance the heat transfer. For high flame temperature oxy-coal combustion, flame temperatures in excess of $4500 \mathrm{~F}$ were achieved and demonstrated to be consistent with computational fluid dynamic modeling of the burner system. The project demonstrated feasibility and effectiveness of the Jupiter Oxygen high flame temperature oxy-combustion process with Integrated Pollutant Removal process for CCS and CCUS. With these technologies total parasitic power requirements for both oxygen production and carbon capture currently are in the range of $20 \%$ of the gross power output. The Jupiter Oxygen high flame temperature oxy-combustion process has been demonstrated at a Technology Readiness Level of 6 and is ready for commencement of a demonstration project. 


\section{TABLE OF CONTENTS}

$\begin{array}{ll}\text { Section Description } & \text { Page }\end{array}$

1.0 Executive summary 5

$\begin{array}{lll}2.0 & \text { Introduction and background } & 7\end{array}$

3.0 Project Objectives 11

4.0 Test facility description 12

5.0 Analysis and test results 20

A Natural gas testing 20

B Coal testing 24

i Air combustion $\quad 24$

ii Oxy-combustion $\quad 27$

C IPR system testing $\quad 45$

6.0 High flame temperature oxy-combustion power plant 67 retrofits

7.0 Evaluation of a retrofit to Connesville \#5 83

8.0 Modular boiler design 84

9.0 Patents and patent applications $\quad 85$

10.0 Current State TRL (Technology Readiness Level) 91 Justification

11.0 Project conclusions $\quad 92$

12.0 List of figures $\quad 94$

13.0 List of tables 96 


\section{Executive summary}

Jupiter Oxygen Corporation has developed and implemented a high flame temperature oxy-combustion process for the aluminum melting furnaces at the Jupiter Aluminum Corporation's Hammond, IN site where significant fuel savings were realized. The intent of this project was to extend the Jupiter Oxygen high flame oxy-combustion technology to utility power plant operations. In the Jupiter Oxygen Corporation oxy-combustion combustion process, fuel and oxygen are mixed at the burner undiluted with recycled flue gas except to motivate coal for coal fired systems. This process can result in a high flame temperature $\left(>4500^{\circ} \mathrm{F}\right)$ which enhances heat transfer in the radiant zone of the boiler. This process also results in more variable heat in the radiant zone of the boiler and can result in a reduction in fuel demand at constant steam generation rates. The specific objectives for this project are as follows.

a. Design, construct, and operate a $5 \mathrm{MWe}$ equivalent test boiler facility

b. Design, construction, and operate a $20 \mathrm{KWe}$ equivalent Integrated Pollutant Removal ${ }^{\circledR}($ IPR $\AA$ ) facility

c. Operate the test facility at steady state optimum oxy-coal combustion and perform parametric studies.

d. Demonstrate oxy-coal combustion NOX levels no higher than 0.15 LB/MMBTU

e. Demonstrate that $\mathrm{CO}_{2}$ from the boiler/IPR® meets the specifications for deep saline aquifer sequestration and/or enhanced oil recovery

f. Evaluate the retrofit impact of oxy-coal combustion and the IPR® process on power plant design issues

g. Generate the necessary technical data required to demonstrate the technologies are viable for technical and economic scale-up and conform to DOE's Carbon Sequestration Program goals

h. Design and construct an air-coal combustion burner for the $5 \mathrm{MWe}$ equivalent test boiler. Operate air-coal burner to develop an air-coal combustion base line for the test boiler.

i. Develop and implement a high flame temperature closed loop control strategy for the $5 \mathrm{MWe}$ equivalent test boiler.

The $5 \mathrm{MWe}$ equivalent test boiler and $20 \mathrm{KWe}$ equivalent Integrated Pollutant Removal ${ }^{\circledR}($ IPR $\circledast$ ) facility was constructed and installed at the Jupiter Aluminum Hammond, IN manufacturing site. The test facility was operated and tested in the following combustion scenarios to determine optimal operating parameters for oxy-combustion and generate the necessary technical data required to demonstrate the technologies are viable for technical and economic scale-up.

a. Air-natural gas combustion

b. Oxy-natural gas combustion 


\section{c. Air-coal combustion \\ d. Oxy-coal combustion}

In each test scenario, performance data was collected for burner, boiler and IPR operation. Test data was compared to process and computational fluid dynamic models of the systems for validation. Based on evaluation of the tests and models the following conclusions are drawn.

a. The project demonstrated feasibility and effectiveness of the JOC high flame temperature oxy-combustion process with Integrated Pollutant Removal process for CCS and CCUS. Economics were enhanced through savings on fuel usage and heat recovery. Water recovery and re-use can also enhance economics depending on specific project conditions.

b. With these technologies total parasitic power requirements for both oxygen production and carbon capture currently are in the range of $20 \%$ of gross power output.

c. Demonstrated that $\mathrm{CO}_{2}$ from the boiler/ IPR® can meets the specifications for deep saline aquifer sequestration and/or enhanced oil recovery but some distillation or other purification may be required.

d. Flame temperatures between 4930-6120F were achieved with high flame temperature oxy-natural gas combustion depending on whether additional re-circulated flue gases are added to balance the heat transfer. For high flame temperature oxy-coal combustion, flame temperatures in excess of $4500 \mathrm{~F}$ were achieved.

e. Both coal and natural gas were found to be fuels which can be used with high flame temperature oxy-combustion and IPR for CCS and CCUS, as well as other environmental improvement. Technical and economic strategies for use of coal and natural gas were outlined.

f. The spectral irradiance data acquired for the pilot scale high temperature oxy-coal flame is unique and can be used to inform future studies. Additionally, an improved technique was realized for flame temperature determination to account for the large particle temperature variations that occur in these flames as compared to air-coal flames.

g. The corrosion study results with 316 SS probes used under buffered IPR conditions showed relative corrosion resistances of 1-5 MPY (milliinch per year) which is considered excellent. Therefore materials more expensive than 316 SS are not required for IPR equipment.

h. The Jupiter Oxygen high flame temperature oxy-combustion process has been demonstrated at a Technology Readiness Level of 6 and is ready for commencement of a demonstration project. 


\section{Introduction and background}

a. Aluminum furnace application

In the 1990s, Dietrich Gross, Chairman and CEO of Jupiter Aluminum Corporation, was concerned about the rising cost of fossil fuel and environmental issues for his business. He envisioned the use of oxygen instead of air for natural gas aluminum melting furnaces. This led to experiments with the use of oxygen in industrial melting furnaces. Knowledge from these experiments led to a new technology for combustion and burner systems for the oxy-combustion combustion process running very close to stoichiometric conditions without ambient air. Although flame temperature exceeded $4,500^{\circ} \mathrm{F}$, and reached as high as $5,300^{\circ} \mathrm{F}$, industrial melting furnace process temperatures were maintained at the same levels as with conventional types of combustion without damage. The molten metal process temperature remained about $1,400^{\circ} \mathrm{F}$, with wall temperatures about $1,800^{\circ} \mathrm{F}$, and stack temperature about $1,000^{\circ} \mathrm{F}$.

The results of using this new technology in industrial melting furnaces were quite dramatic. Compared to traditional air-fossil fuel, equivalent product was produced with a natural gas fuel reduction of up to $73 \%$ and a waste oil fuel usage reduction up to $68 \%$. For aluminum, $1,008 \mathrm{Btu} / \mathrm{Lb}$ was the average energy requirement, which improved to 750-900 Btu/lb with continuous runs eliminating holding time. This compares to the prior experience with air fuel of about 3,620 Btu/Lb, which was expected for air fuel combustion in that industry segment.

The oxy-combustion combustion process has been in operation at the Jupiter Aluminum Corporation melting furnaces since 1997.

b. CRADA study (2003)

The oxy-combustion technology development at the Jupiter Aluminum Corporation was then transferred from industrial melting furnaces to fossil fuel steam generators and power plants, focusing on efficiency and emissions benefits. Cooperation was received from the VicePresident's Energy Task Force, the Department of Energy, and its National Energy Technology Laboratory.

Operational experience with using high flame temperature oxycombustion in industrial melting furnaces while maintaining the same material and process temperatures as air firing was used to determine the application of the heat transfer process to the radiant zones of existing air fired boilers.

In addition to efficiency and emissions benefits, the capture and sequestration of $\mathrm{CO}_{2}$ emissions from fossil fuel power plants and melting furnaces can be enhanced via oxy-combustion. The oxy- 
combustion combustion process reduces or completely eliminates nitrogen from the feed gas to the combustor and hence produces a flue gas with high $\mathrm{CO}_{2}$ concentration. With higher $\mathrm{CO}_{2}$ concentration in the flue gas, the capture process can be simplified, reduced in energy demand, and reduced capital cost.

A pilot-scale test facility was built and dedicated to natural gas and coal oxy-burner combustion, burner systems development, and $\mathrm{CO}_{2}$ capture studies. The test boiler was a Keeler 'D'-type saturated steam boiler designed to be fired with a single air-fuel natural gas burner. The boiler was rated at $12,500 \mathrm{lb} / \mathrm{hr}$ and $250 \mathrm{psig}$.

The test results from this program provided valuable insights on the impact on combustion performance due to combustion medium, burner swirl and burner configuration. Also the program demonstrated the following key points.

- Successful retrofit of $0.5 \mathrm{MWe}$ equivalent boiler with JOC high flame temperature oxy-combustion process

- Produced saturated steam while maintaining boiler interior temperature profiles the same as with air firing.

- Boiler efficiency gains resulted.

c. Application to utility power plants

In the application of oxy-combustion combustion to utility power plants, air is eliminated from the combustion system and pure or nearly pure oxygen from a generation source is introduced as the fuel oxidant. In many oxy-combustion combustion systems, the pure oxygen is premixed with recycled flue gas to make a "synthetic" air in the range of $21 \%$ to $30 \%$ oxygen. This "synthetic" air is then mixed with the fuel at the burner and used as motive gas for coal combustion systems. These types of oxy-combustion combustion systems are effective at eliminating air from the combustion system, but produce a low flame temperature in the radiant section of the boiler similar to aircombustion systems.

In the Jupiter Oxygen Corporation (JOC) oxy-combustion combustion process, fuel and oxygen are mixed at the burner undiluted with recycled flue gas except as to motivate coal for coal fired systems. This process can results in a high flame temperature $\left(>4500^{\circ} \mathrm{F}\right)$ which enhances heat transfer in the radiant zone of the boiler. This process also results in more variable heat in the radiant zone of the boiler and can result in a reduction in fuel demand at constant steam generation rates.

Recycled flue gas can be introduced to the boiler system around the flame/combustion zone to adjust the total flue gas volume flow without impacting the high flame temperature in the combustion zone. 
Recycled flue gas around the combustion zone can also be effective to transfer heat duty from the radiant to the convective zone of the boiler as required to achieve the desired steam superheat temperature exiting the boiler system. It may also be effective to utilize the JOC high flame temperature process without recycled flue gas and add an auxiliary oxy-combustion superheater or other convective zone heat boosts to achieve desired steam superheat temperature exiting the system.

The elimination of air/nitrogen from the combustion system has the power utility benefit of reduced NOX generation at combustion and therefore reduced emission control power demand and capital costs. Also, the elimination of air/nitrogen allows for a flue gas exiting the boiler system with a much higher concentration of $\mathrm{CO}_{2}$ than air combustion systems. The flue gas from the oxy-combustion process is primarily $\mathrm{CO}_{2}$ and water which enhances the feasibility of carbon capture.

d. Integrated Pollutant Removal process

NETL's Integrated Pollutant Removal $\left(\mathrm{IPR}^{\circledR}\right)$ process captures emissions from oxy-fired fossil-fueled power plants while simultaneously recovering latent and sensible heat from the combustion products. Cooperative testing and development that mated Jupiter Oxygen Corporation's high-temperature oxy-combustion approach to NETL's IPR process provides data that can be used to design and engineer near-zero emissions power plants. A joint patent for the design of such a power plant was awarded in October of 2011 (following 2 prior patents developed in this project).

In order to use hydrocarbon fuel (e.g. coal, oil, natural gas) without adding to the $\mathrm{CO}_{2}$ content of the atmosphere, the $\mathrm{CO}_{2}$ produced from combustion can be captured and either stored or utilized in other applications rather than released to the air. Deep aquifers and mineral deposits have been demonstrated to be suitable for long-term $\mathrm{CO}_{2}$ storage (sequestration). $\mathrm{CO}_{2}$ must be purified and compressed to approximately 2000 psi in order to inject the $\mathrm{CO}_{2}$ to sufficient depth. Capturing and compressing $\mathrm{CO}_{2}$ requires power which decreases the power plant's net electricity output. To minimize this parasitic loss, the IPR process recovers energy from the unit processes and integrates the recovered energy into the power plant's working fluid (steam). It accomplishes this by recovering latent and sensible heat contained in the combustion gasses in addition to heat generated by the compression process.

To capture $\mathrm{CO}_{2}$ in oxy-combustion power production practice, fuel is burned with oxygen instead of air (air is about 79\% nitrogen, 20\% 
oxygen and $1 \%$ other gases). Therefore, oxy-combustion exhaust is mostly undiluted by nitrogen, making the $\mathrm{CO}_{2}$ easier to capture. $\mathrm{CO}_{2}$ and water make up $93.8 \%$ of the exhaust mixture with smaller amounts of acid gases $\left(\mathrm{SO}_{x}, \mathrm{NO}_{x}, \mathrm{Cl}_{\mathrm{x}}, \mathrm{N}_{2}, \mathrm{O}_{2}\right.$ and $\mathrm{Ar}$ ) and heavy metals (like mercury from the coal). Entering the IPR process, hot, the exhaust releases its heat to a water-spray in a scrubbing tower. Water contained in the exhaust precipitates, leaving a cooled gas which contains much less water (only the water that can remain vapor at the cooled-gas temperature). The remaining gas goes through a compression and cooling process repeatedly, releasing heat and condensing water (containing pollutants) at each stage. Some of the heat released from IPR is captured into the boiler feed water via heat exchangers handling IPR process water and boiler feed water. Latent and sensible heat is thereby transferred back into to the power plant thermal cycle. Captured water is cleaned for reuse in the plant or released back to the environment.

e. Oxy-combustion and IPR ${ }^{\circledR}$ carbon capture process schematic

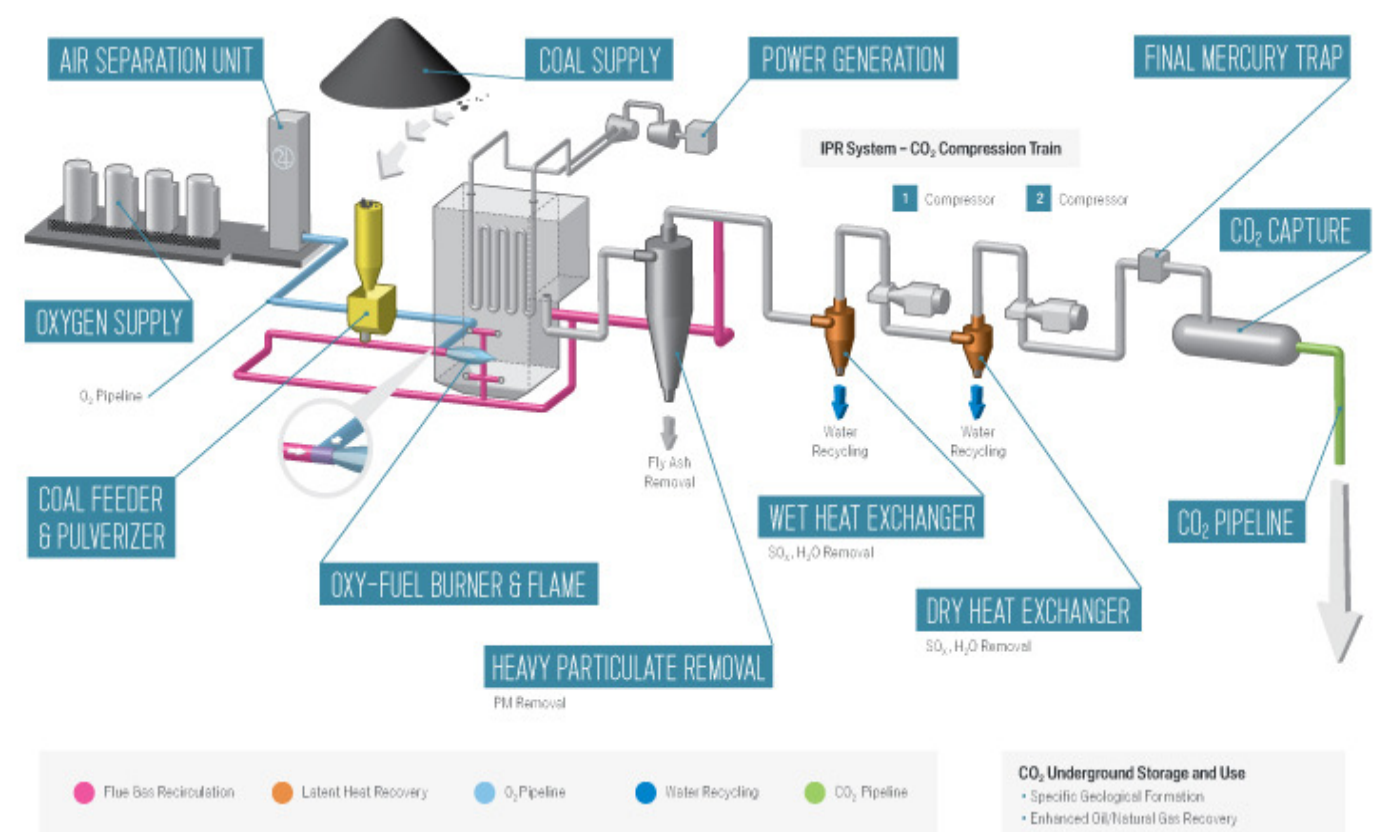

Figure 1: Oxy-combustion combustion and IPR ${ }^{(\Theta)}$ carbon capture process schematic 
3. Project objectives

This NETL/JOC funded project has the overall objective to extend the work of the 2003 CRADA study and demonstrate the JOC high flame temperature oxy-combustion process with Integrated Pollutant Removal process. The specific project objectives are as follows.

a. Design, construct, and operate a $5 \mathrm{MWe}$ equivalent test boiler facility

b. Design, construction, and operate a $20 \mathrm{KWe}$ equivalent IPR $\AA$ facility

c. Operate the test facility at steady state optimum oxy-coal combustion and perform parametric studies.

d. Demonstrate oxy-coal combustion NOX levels no higher than 0.15 LB/MMBTU

e. Demonstrate that $\mathrm{CO}_{2}$ from the boiler/ IPR® meets the specifications for deep saline aquifer sequestration and/or enhanced oil recovery

f. Evaluate the retrofit impact of oxy-coal combustion and the IPR® process on power plant design issues

g. Generate the necessary technical data required to demonstrate the technologies are viable for technical and economic scale-up and conform to DOE's Carbon Sequestration Program goals

h. Design and construct an air-coal combustion burner for the $5 \mathrm{MWe}$ equivalent test boiler. Operate air-coal burner to develop an air-coal combustion base line for the test boiler.

i. Develop and implement a high flame temperature closed loop control strategy for the $5 \mathrm{MWe}$ equivalent test boiler. 
4. Test facility description

A $5 \mathrm{MWe}$ equivalent boiler test facility with a $20 \mathrm{KWe}$ equivalent IPR $\AA^{8}$ test facility has been constructed at Jupiter Aluminum's Hammond, Indiana manufacturing site. The following is a description of the major equipment included in the test facility.

a. Boiler

The test facility boiler is a used B\&W type " $\mathrm{D}$ " bent tube boiler rated at $74 \mathrm{MMBtu} / \mathrm{hr}$ heat input and 60,000 Lb/hr steam generation at $135 \mathrm{psig}$ and $454^{\circ} \mathrm{F}$.

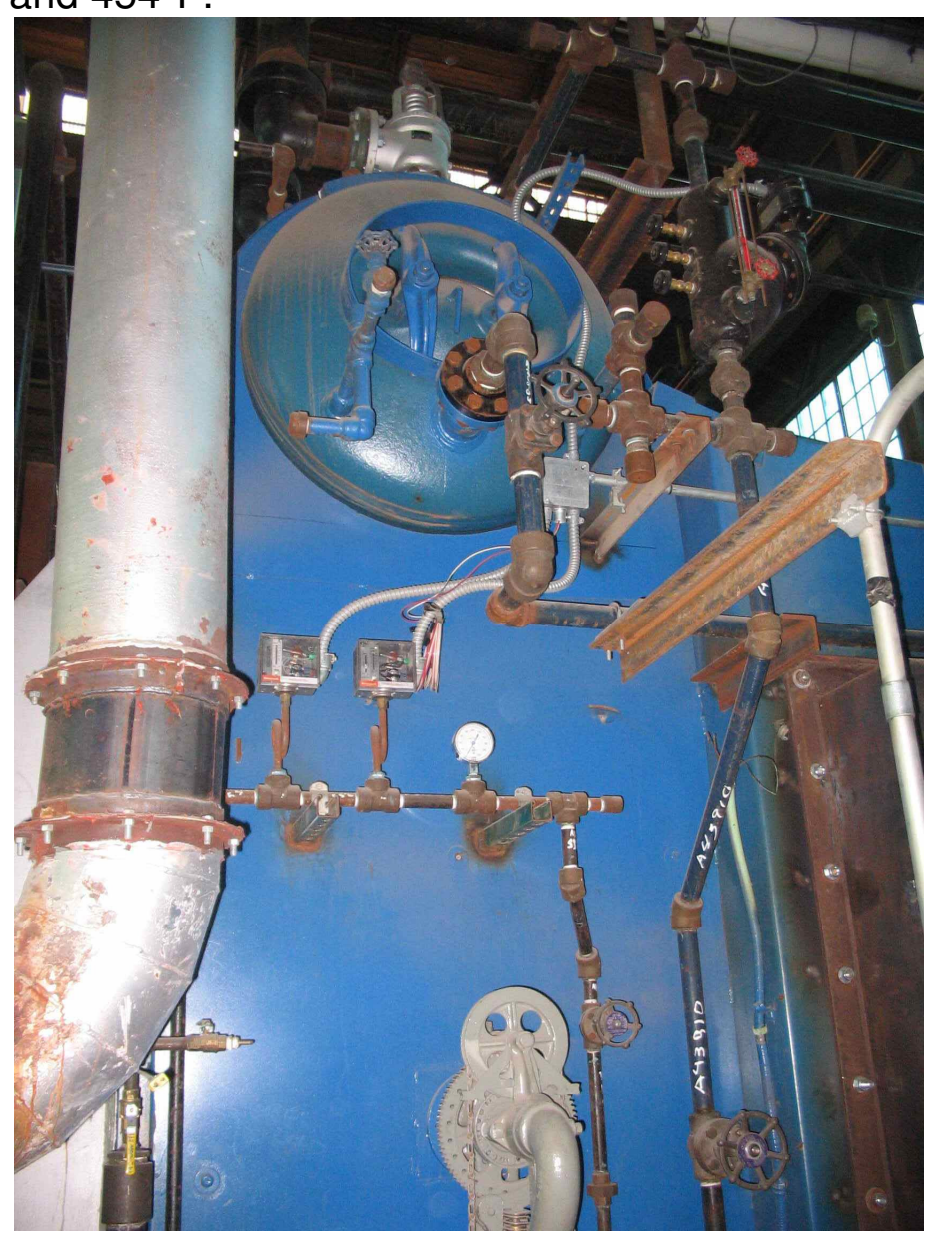

Figure 2: B\&W test boiler at the JOC test facility

b. Burner

The JOC Hammond Test Facility boiler was tested with several burner systems including commercially available burners and custom oxycombustion burners designed in cooperation with Maxon and fabricated by Maxon.

i. Maxon Oxy-Natural Gas

Four Maxon commercially available burners rated for 10 MMBtu/hr heat output each. 


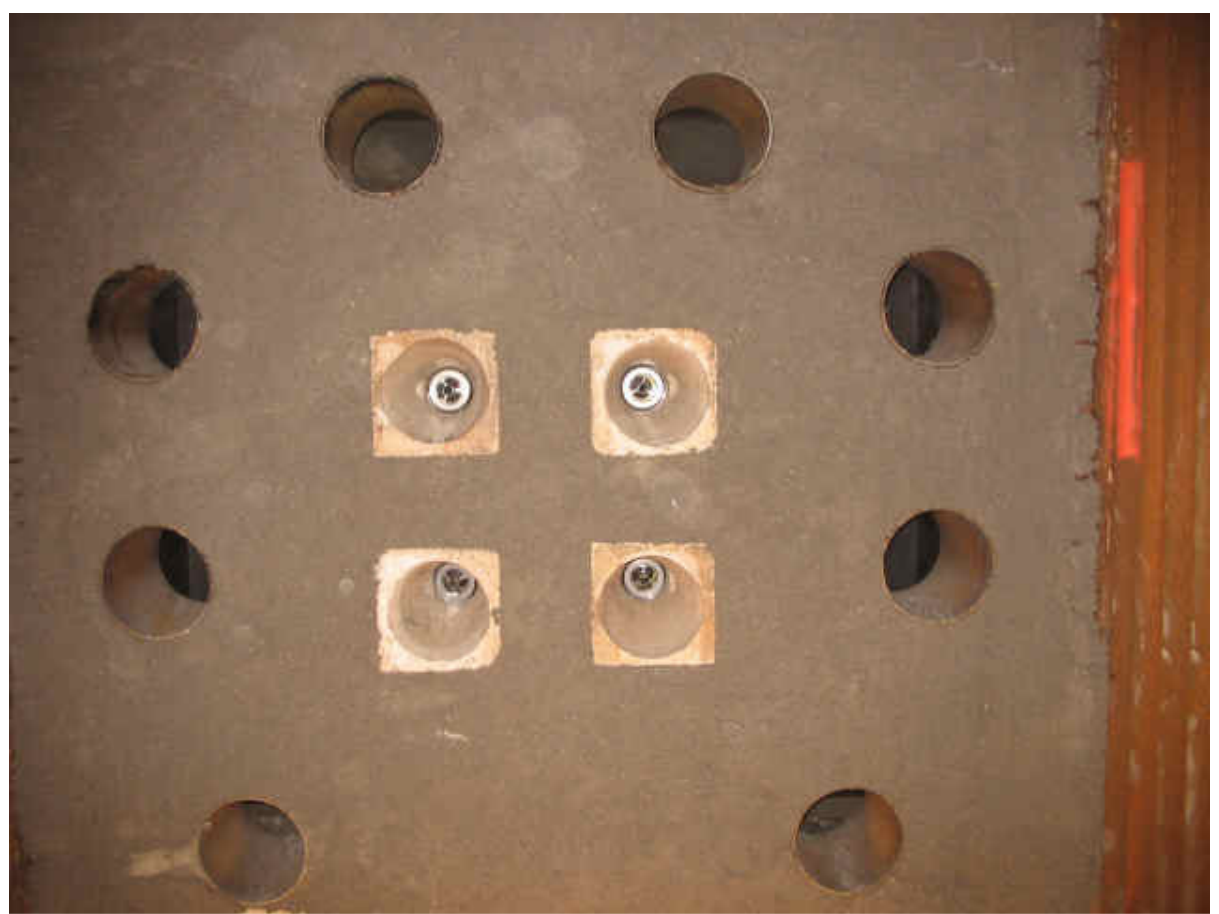

Figure 3: Maxon oxy-natural gas four burner assembly (view from inside the boiler)

ii. Gordon-Piatt burner

Used Gordon-Piatt F22 turbo ring forced draft burner package rated at $42 \mathrm{MMBtu} / \mathrm{hr}$ heat output. This commercial burner design for air - natural gas operation was utilized for air-natural gas testing and later retrofitted by JOC for low temperature oxynatural gas combustion testing.

iii. Maxon Oxy-Coal burner

The Maxon oxy-coal burner rated at $40 \mathrm{MMBtu} / \mathrm{hr}$ heat output was custom designed in cooperation with JOC. This burner design evolved through several stages during the course of this project with design input from actual test results. The original design was scaled up from the previous CRADA work as a single tube burner with oxygen/coal mixing at the nozzle exit. The final burner design (GEN 2.1) includes tangential mixing nozzles for coal and oxygen prior to ignition at the burner nozzle exit. 


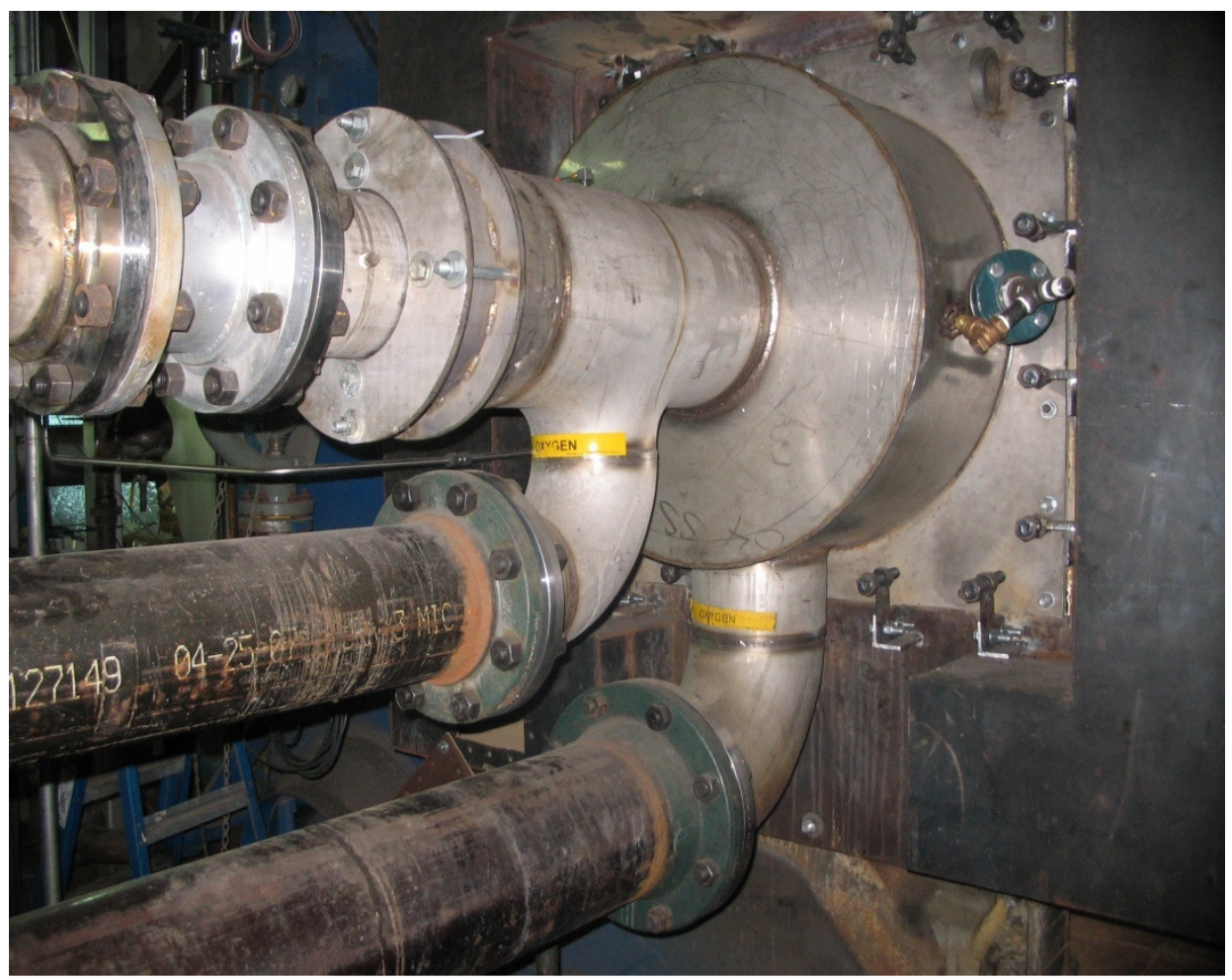

Figure 4: Typical Maxon oxy-coal burner configuration and mounting to the B\&W boiler.

iv. Riley Power Air-Coal burner

This 3M-S VS III Riley Power burner was a custom designed modification of a commercially available air-coal burner package rated for $40 \mathrm{MMBtu} / \mathrm{hr}$ heat output. This burner was utilized for air-coal combustion base line testing in the B\&W test facility boiler.

c. Coal delivery system

The coal pulverizer is a C-E Raymond Bowl Mill model 372A with a base capacity of $7,100 \mathrm{lbs} / \mathrm{hr}$ on 55 grindability coal pulverized to $70 \%$ through 200 mesh. Mill is capable of grinding down to $90 \%$ through 200 mesh. The mill and exhauster are direct driven by a 75HP, 3 phase, 480V, 1800 RPM Motor. Pulverized coal from the mill blown from the exhaust into a fuel hopper holding tank. The top of the tank is equipped with a dust collector bag house to prevent coal dust from escaping to the atmosphere. Coal from the bottom of the hopper is feed into an Acrison screw feeder. The screw feeder is controlled by a variable speed motor to adjust the feed rate of coal into the burner. Coal from the screw feeder is dropped vertically into a 6" motive gas pipe. The coal is then suspended in the motive gas and carried into the burner. 
d. IPR

The IPR test facility located at JOC's Hammond, IN site was designed and constructed to process a slipstream of approximately $100 \mathrm{lb} / \mathrm{hr}$ of flue gas from the exit of the JOC test boiler. The test IPR was constructed with market-available reciprocating compressors, a Pyrex ${ }^{\circledR}$ spray tower with re-circulating spray liquid and stainless steel tube-intube heat exchangers which employ cooling-tower make-up water as coolant.

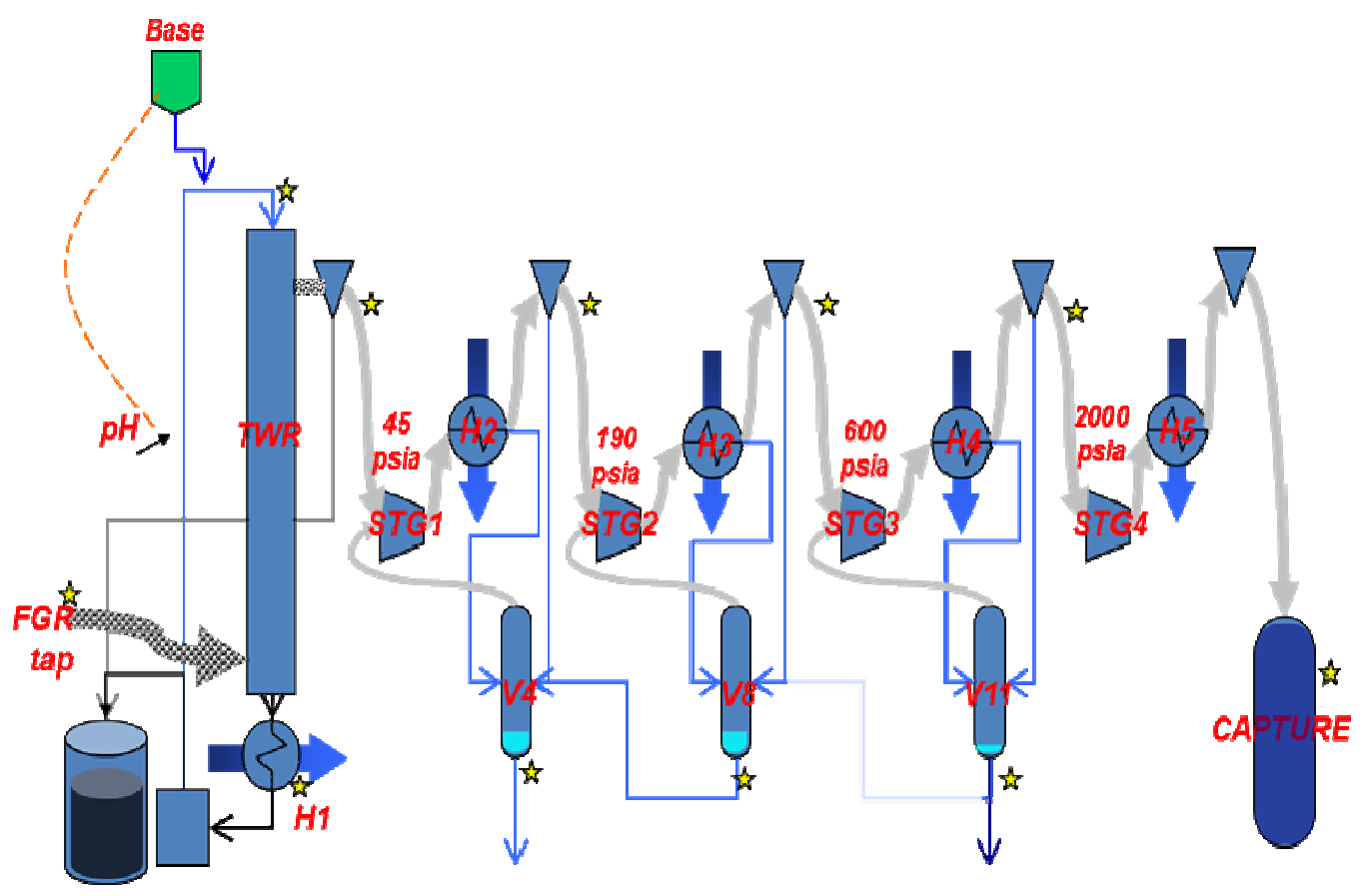

Figure 5: IPR flow diagram

$\mathrm{FGR}$ = flue-gas recirculation; $\mathrm{H}=$ heat exchanger; $\mathrm{STG}=$ compression stage; $\mathrm{V}=$ vessel. 


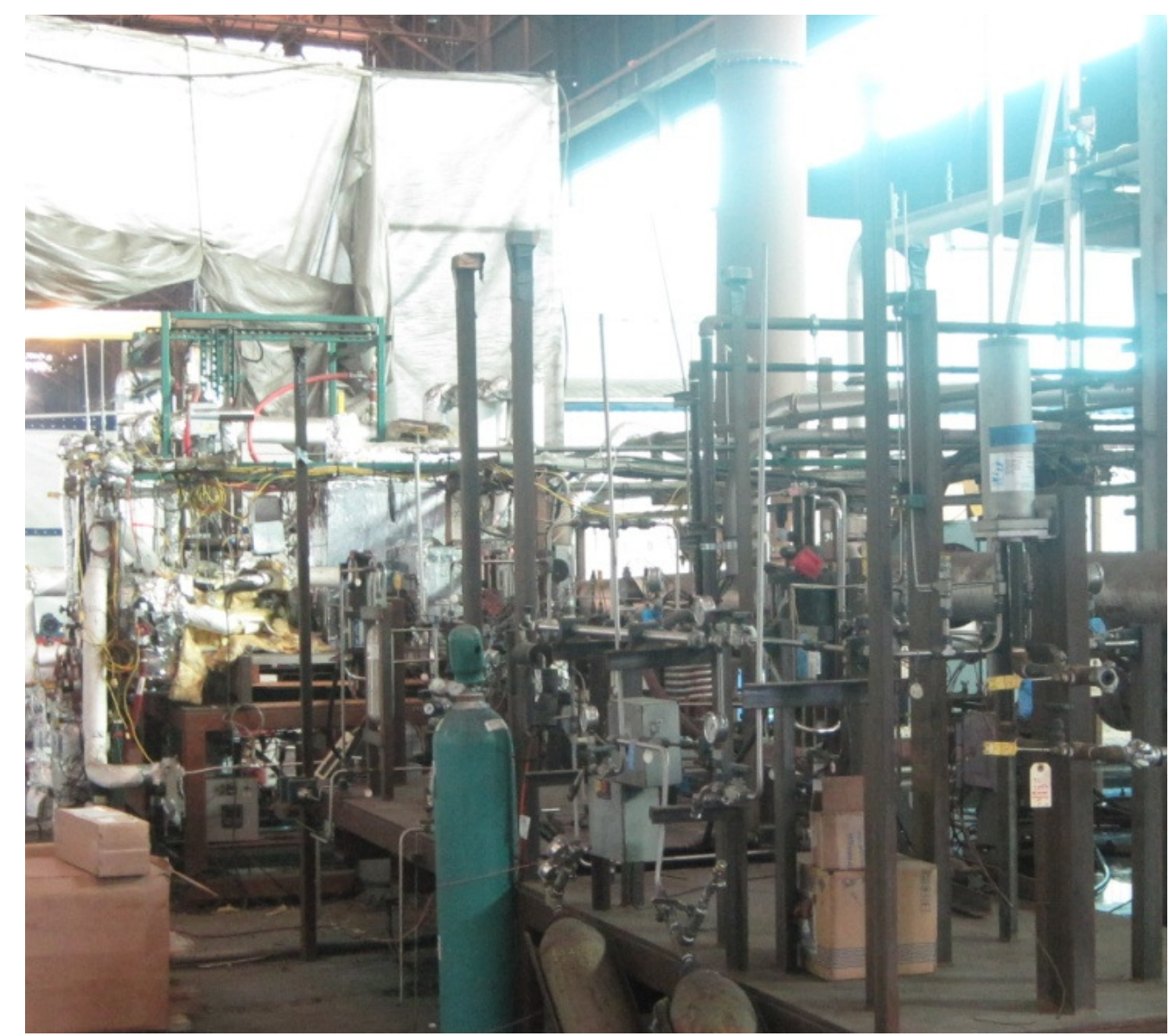

Figure 6: Installed IPR photographed

A slip stream of flue gas from the exit of the $\mathrm{JOC}$ boiler passed through a counter-current wet scrubber or tower. The gas then underwent 4 stages of compression to 45, 190,600, and 2000 PSIG. After each stage of compression, the gas was cooled and the heat recovered. This cooling also condensed water, which was recovered for analysis. The system included sample ports after each pressurization stage to allow measurement of the gas composition. Most gas measurements were taken with an FTIR. The FTIR was capable of measuring the gas composition in real time. However, the FTIR technique could not measure $\mathrm{Ar}, \mathrm{N}_{2}$, or $\mathrm{O}_{2}$. This FTIR was equipped with a separate oxygen sensor. Because of this limitation, there were no IPRmeasured numbers for $\mathrm{N}_{2}$ or $\mathrm{Ar}$ and the sum of $\mathrm{N}_{2}+\operatorname{Ar}$ was estimated by difference. Estimation by difference is not ideal, therefore a gas chromatograph was employed to measure nitrogen explicitly.

e. Instrumentation

i. Process instrumentation

The test facility was thoroughly instrumented with temperature, pressure, and flow measurements. Process instrumentation 
was run into a PLC based data acquisition system for recording and process control.

ii. Flame temperature and radiometer measurements

A unique suite of instrumentation has been designed and deployed for the purpose of oxy-combustion combustion flame characterization: two monochromators, four total radiometers, two fiber optic CCD spectrometers, a video camera, 6 calibrated chordal tubes, and 16 webbing thermocouples. This instrumentation is capable of capturing the following flame components: temperature, radiance, stability, and morphology.

\begin{tabular}{|c|c|c|c|}
\hline Instrument & $\begin{array}{l}\# \\
\text { units }\end{array}$ & $\begin{array}{l}\text { Primary } \\
\text { Measurement }\end{array}$ & Comments \\
\hline $\begin{array}{l}\text { NETL } \\
\text { monochromator }\end{array}$ & 2 & $\begin{array}{l}\text { Flame } \\
\text { Temperature } \\
(\mathrm{K}), \\
\text { Spectral } \\
\text { Irradiance } \\
\left(\mathrm{W} / \mathrm{m}^{\wedge} 2-\mathrm{nm}\right)\end{array}$ & $\begin{array}{l}\text { Narrow field, } \\
900 \text { to } \\
5000 \mathrm{~nm} \\
\text { detection }\end{array}$ \\
\hline $\begin{array}{l}\text { NETL } \\
\text { radiometer }\end{array}$ & 4 & $\begin{array}{l}\text { Flame } \\
\text { Radiance } \\
\left(\mathrm{W} / \mathrm{m}^{\wedge} 2-\mathrm{sr}\right)\end{array}$ & $\begin{array}{l}\text { Narrow field, } \\
200 \\
7000 \mathrm{~nm} \\
\text { detection }\end{array}$ \\
\hline $\begin{array}{l}\text { Stellarnet UV- } \\
\text { VIS-NIR ccd } \\
\text { spectrometer }\end{array}$ & 2 & $\begin{array}{l}\text { Flame } \\
\text { Temperature } \\
(\mathrm{K}) \quad \text { and } \\
\text { Species () }\end{array}$ & $\begin{array}{l}\text { Narrow field, } \\
280 \\
1000 \mathrm{~nm} \\
\text { detection }\end{array}$ \\
\hline $\begin{array}{l}\text { Babcock } \\
\text { Chordal Tubes }\end{array}$ & 6 & $\begin{array}{lr}\text { Boiler Tube } & \text { Tubl Heat } \\
\text { Total } & \text { Flux }\left(\mathrm{kW} / \mathrm{m}^{\wedge} 2\right)\end{array}$ & $\begin{array}{l}\text { Custom } \\
\text { calibration } \\
\text { for high } \\
\text { accuracy }\end{array}$ \\
\hline $\begin{array}{l}\text { K-type } \\
\text { thermocouples }\end{array}$ & 16 & $\begin{array}{l}\text { Wall } \\
\text { Temperature } \\
\text { (K) }\end{array}$ & $\begin{array}{l}\text { Webbing } \\
\text { Temperature }\end{array}$ \\
\hline $\begin{array}{l}\text { Lenox Firesite } \\
\text { Camera }\end{array}$ & 1 & $\begin{array}{l}\text { Flame } \\
\text { Morphology \& } \\
\text { Stability }(\mathrm{m}, \mathrm{m}) \\
\& \mathrm{f}(\mathrm{t})\end{array}$ & $\begin{array}{l}\text { Visualize } \\
\text { entire flame }\end{array}$ \\
\hline
\end{tabular}

Table 1: Flame temperature instruments and their capability.

The spectrometer, radiometers, and monochromators view the flame via optical ports mounted along the flame axis on the east 
side of the furnace. Some ports are located along the burner centerline, and some 16" below the centerline. This is shown in figure 7 .

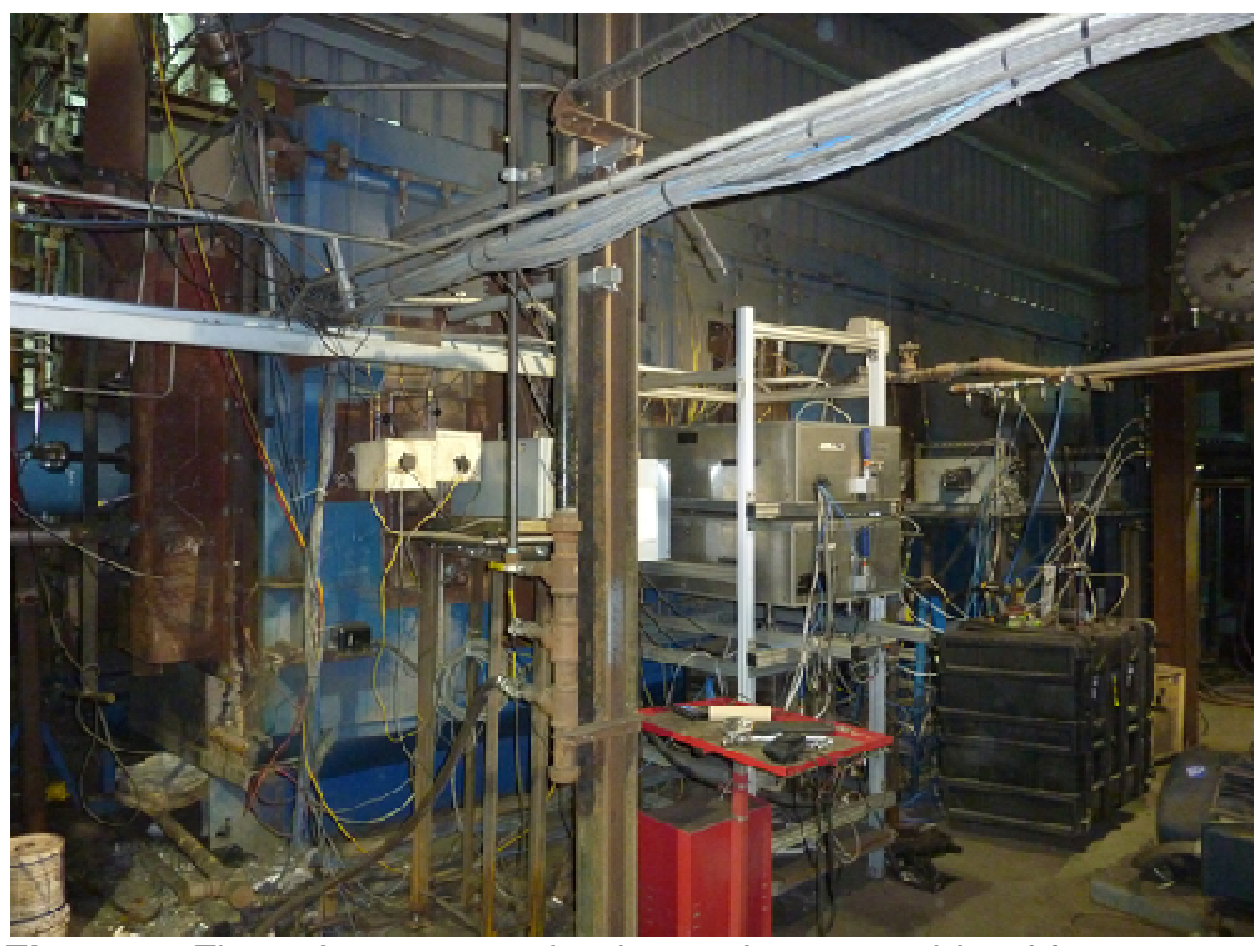

Figure 7: Flame Instrumentation located on east side of furnace

The monochromator records irradiance vs. wavelength over the range of $800-5000 \mathrm{~nm}$. Monochromators are set at the same axial distance from the burner, with one viewing the flame centerline and the other viewing 16 " below centerline. The radiometers record total radiant flame intensity over the range of 200-7000 nm and are located along the burner centerline axis, allowing for a flame intensity profile along the flame length. The radiometers are also able to indicate flame oscillatory behavior. The CCD spectrometers provide instantaneous and continuous radiance vs. wavelength spectra in the range of $230-1100 \mathrm{~nm}$. CCD spectrometer data are applied to calculate average flame temperature in their viewing area using the three-color method (evaluating the radiance ratio at three wavelengths). Rapid scan times enable the spectrometers to also indicate oscillations in the flame. Flame stability and morphology are monitored with a high speed video camera with a $90^{\circ}$ field of view that has been customized for high temperature flame use. This camera is situated so that nearly the entire length of the flame is recorded. 
5. Analysis and results

a. Natural gas testing

i. Introduction and background

Although the primary objective of this NETL/JOC funded project was to perform high flame temperature oxy-coal combustion testing with the $5 \mathrm{MWe}$ test facility, in order to gain operating experience with the facility and prove out instrumentation systems, a series of natural gas test in both air and oxycombustion were conducted. In addition these tests provided a demonstration and comparison of the performance of the 5 MWe test boiler in air and oxy/natural gas combustion service.

For the air combustion tests. the test boiler was fitted with a Gordon Piatt F22 burner package rated at $42 \mathrm{MMBtu} / \mathrm{hr}$. A series of air combustion tests were conducted at approximately $30 \mathrm{MMBtu} / \mathrm{hr}$.

Similarly the test facility boiler was fitted with a Maxon natural gas/oxy-combustion package. The Maxon burner system consisted of four $10 \mathrm{MMBtu} / \mathrm{hr}$ burners and is shown in figure 7 above. Testing with the Maxon burner included several test runs at various duties and flue gas recycle rates.

Due to limitations of the test facility equipment for recondensing the superheated steam generated by the test boiler, the firing rate was limited during natural gas testing to approximately 30 $\mathrm{MMBtu} / \mathrm{hr}$. Since this test firing rate is a significant turndown from the boiler design firing rate of $74.5 \mathrm{MMBtu} / \mathrm{hr}$, the airnatural gas testing defines a base line performance of the test boiler at the $30 \mathrm{MMBtu} / \mathrm{hr}$ firing rate. The base performance of the test boiler in air-natural gas firing shows an average boiler efficiency (enthalpy change from boiler feed water to superheated steam/ HHV of the natural gas input) of $82.4 \%$. It also shows that $40 \%$ of the heat extracted from combustion and the hot flue gas occurs in the convective (back) pass of the boiler.

In the JOC high flame temperature oxy-natural gas combustion process, the flue gas flow rate is reduced to $27.6 \%$ of the equivalent flow gas flow rate for air firing due to the elimination of nitrogen from the system. As a result of this reduced flue gas flow rate, there is a much higher percentage of heat extracted from combustion and the hot flue gas in the radiant (front) pass of the boiler when compared to air firing. This effect can be offset by recycling a portion of the flue gas from the boiler exit which increases the equivalent air molar volume flue gas flow 
rate and increasing the energy entering the back pass. The recycle was introduced at distance and direction from the burner so that flame temperature was not lowered. The equivalent air molar volume flue gas flow rate is defined as the sum of the oxygen and recycled flue gas molar flow divided by the equivalent air molar flow required for air firing. By increasing the flue gas recycle rate (equivalent air molar volume flow rate) the percentage of heat extraction available for the convective (back) pass increases. However due to capacity limitations of the test facility flue gas recycle blower, oxy-natural gas tests were not able to match the radiant and convective heat balance of air firing. With the maximum flue gas recycle flow rate capacity only $30 \%$ of the heat extraction was available for the convective pass. By not matching the heat extraction balance of air firing, the high flame temperature oxy-combustion test cases at equivalent burner heat input achieve higher steam flow rates but lower superheated stream temperature as compared to air firing.

Testing shows that high flame temperature heat transfer could be balanced between the radiant and convective zones by recirculating additional flue gas away from the flame to reduce radiant zone residence time without cooling the flame. For retrofit projects, engineering will determine as to whether there also needs to be any other modification, as explained in the retrofit section below.

In addition to the shift of heat extraction from the radiant to the convective pass, the intensity of the flame measured at port IR2 (located $8 \mathrm{ft}$ down the radiant pass from the burner) is shown in figures 8 and 9 at $27.6 \%$ and $58.1 \%$ equivalent air molar volume flue gas flow rate respectively. It can be seen in these two figures that the flame intensity near the burner decreases as the flue gas recycle rate is increases and moves the heat extraction further downstream.

Similarly figure 10 shows a normalized plot of heat flux measured by two chordal thermocouple assemblies located along the radiant side of the boiler. Chordal assembly \#1 is located about $12 \mathrm{ft}$ from the burner and chordal assembly \#2 is located about $3 \mathrm{ft}$ from the boiler. It can be seen that as equivalent air molar flow flue gas flow rate (flue gas recycle) is increased the heat flux at any fixed position in the radiant pass decreases and peak heat flux shifts from chordal \#2 to chordal $\# 1$. 


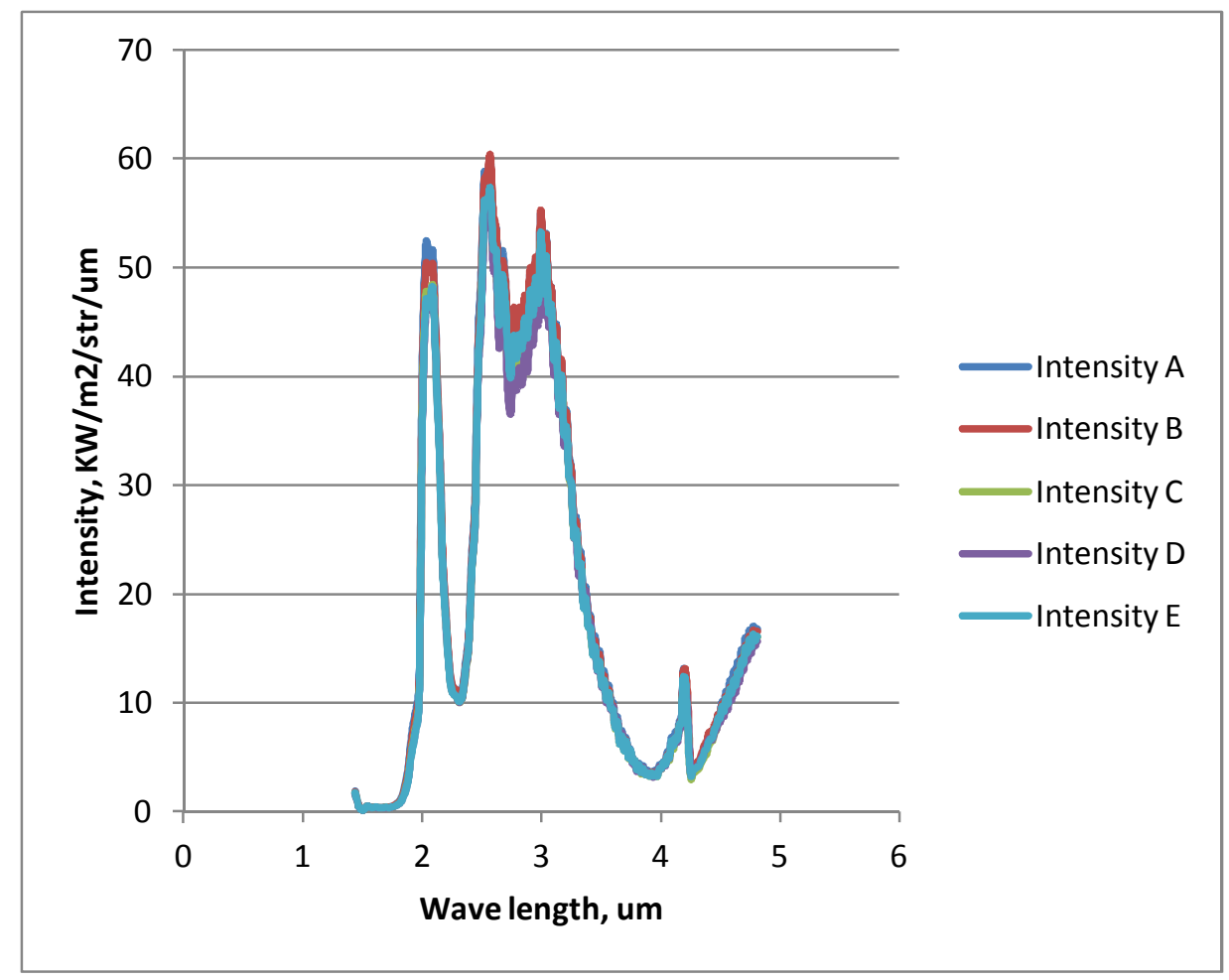

Figure 8: Composite spectraline data, NG test 23, IR port 2 flame centerline, boiler duty $30 \mathrm{MMBtu} / \mathrm{hr}$, Equiv air molar volume $27.6 \%$.



Figure 9: Composite spectraline data, NG test 24, IR port 2 flame centerline, boiler duty $29 \mathrm{MMBtu} / \mathrm{hr}$, Equiv air molar volume $58.1 \%$. 


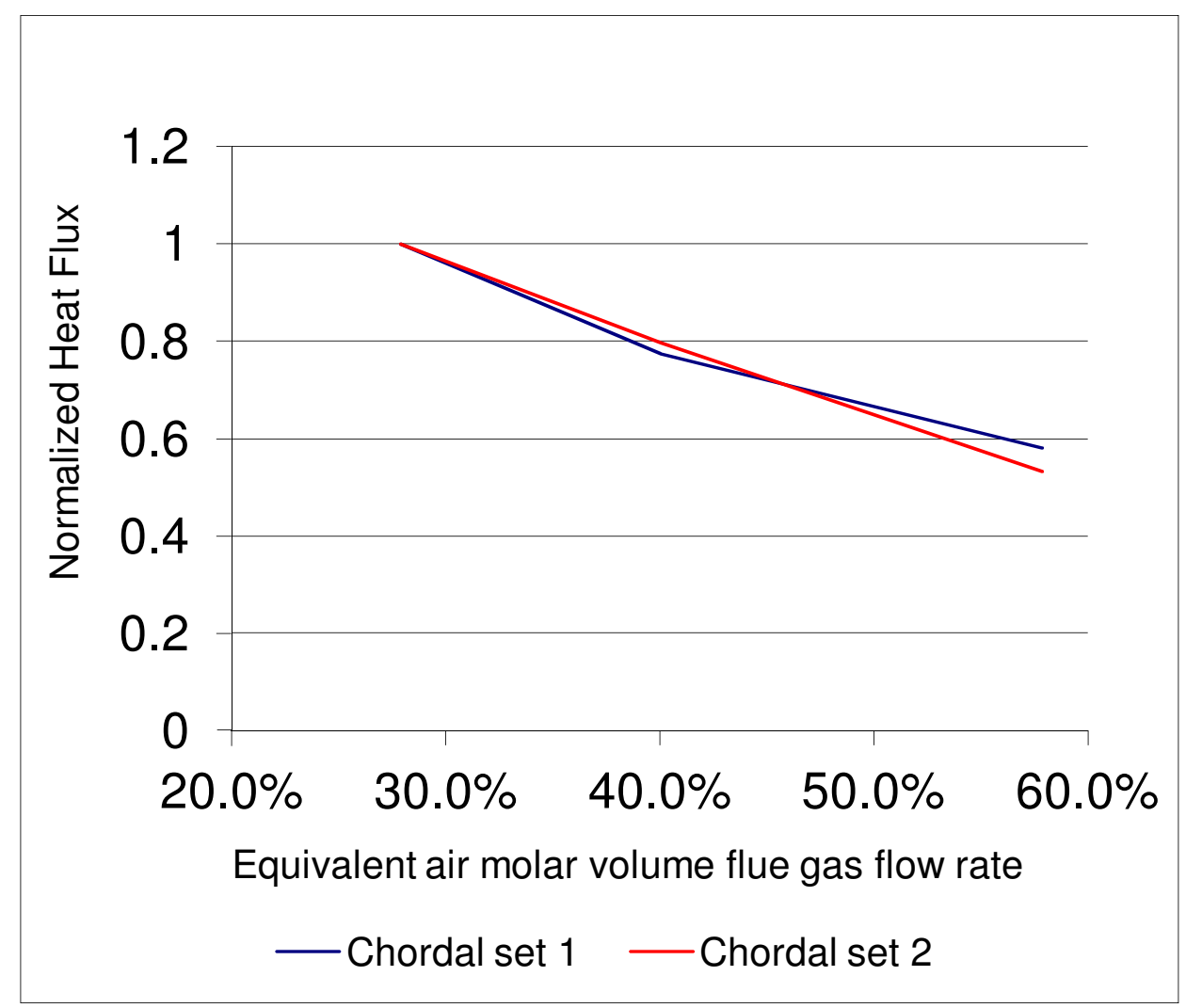

Figure 10: Normalized heat flux for high flame temperature oxynatural gas tests, boiler duty $\sim 30 \mathrm{MMBtu} / \mathrm{hr}$.

Comparing air-natural gas test data to high flame temperature oxy-natural gas test data the fuel input for the oxy-natural gas case was reduced so as to match the steam production from the air-natural gas test. As noted above however the superheated steam temperature still falls short of the air combustion case. Therefore the duty and fuel requirements are calculated for an auxiliary steam superheater to raise the superheated steam temperature to match the air combustion case. The duty for this auxiliary superheater is $1.5 \%$ of the duty of the main boiler. Comparing the total fuel input required for the two cases it is shown that there is a net $4.6 \%$ fuel savings at combustion for the JOC high flame temperature approach compared to air firing.

It is also important to note that the flue gas recycle in the JOC test boiler was introduced outside the combustion zone so as not to dilute the oxygen content in the combustion zone and maintain the desired high flame temperature oxy-combustion. The outside circle of holes in figure 3 shows the flue gas recycle ports located away from the four oxygen and natural gas burner nozzles in the center. Flame temperature measurements taken 
by NETL and a team from Purdue University are shown below in table 2 .

\begin{tabular}{|l|c|c|c|}
\hline & $\begin{array}{c}\text { Air-natural } \\
\text { gas } \\
\text { combustion }\end{array}$ & \multicolumn{2}{|c|}{$\begin{array}{c}\text { High flame temperature oxy- } \\
\text { natural gas combustion }\end{array}$} \\
\hline & & $\begin{array}{c}\text { No flue gas } \\
\text { recycle }\end{array}$ & $\begin{array}{c}\text { w/ flue gas } \\
\text { recycle }\end{array}$ \\
\hline Burner duty, MMBtu/hr & 31 & 30 & 29 \\
\hline $\begin{array}{l}\text { Equivalent air molar volume } \\
\text { flue gas flow rate }\end{array}$ & $100 \%$ & $27.60 \%$ & $58 \%$ \\
\hline Flame temperature, ${ }^{\circ} \mathrm{F}$ & & & 5301 \\
\hline Purdue & 3758 & 5436 & 4930 \\
\hline NETL (Wein displacement) & & 4924 & 5158 \\
\hline Adiabatic flame temperature & 3443 & 5175 & \\
\hline
\end{tabular}

Table 2: Flame temperature measurements for natural gas testing

As can be seen in the above results, the JOC high flame temperature oxy-natural gas combustion achieves the target flame temperatures as indicated in the patents described in section 1.c above. Also the results indicate that there is no significant impact of flue gas recycle on the flame temperature due to its injection outside the combustion zone.

b. Coal testing

i. Air combustion

1. Burner description

The air-coal burner for the Hammond Test Facility was a custom designed burner by Riley Power to fit the packaged boiler of the test facility. This 3M-S VS III Riley Power burner was a modification of a commercially available air-coal burner package rated for $40 \mathrm{MMBtu} / \mathrm{hr}$ heat output with the following design conditions.

\begin{tabular}{|l|l|}
\hline Burner rating & $40 \mathrm{MMBtu} / \mathrm{hr}$ \\
\hline Coal flow & $3379 \mathrm{Lb} / \mathrm{hr}$ \\
\hline Coal heating value $(\mathrm{HHV})$ & $11,837 \mathrm{Btu} / \mathrm{lb}$ \\
\hline $\begin{array}{l}\text { Primary/motive air } \\
\text { Flow rate }\end{array}$ & $5745 \mathrm{Lb} / \mathrm{hr}$ \\
Temperature & $160^{\circ} \mathrm{F}$ \\
Nozzle pressure drop & 4.5 'WC \\
\hline Secondary air & $31,077 \mathrm{Lb} / \mathrm{hr}$ \\
Flow rate & $620^{\circ} \mathrm{F}$ \\
Temperature & \\
\hline
\end{tabular}


2. Combustion air delivery system

Atmospheric air is raised in pressure via a centrifugal blower previously used for flue gas recycle service during oxy-combustion testing. The compressed air was then fed to two parallel natural gas fired heaters rated at 2.0 MMBtu/hr each with the capability to raise the total combustion air to $620^{\circ} \mathrm{F}$. Since the primary air for coal motive gas required a lower temperature, a portion of the cold air from the feed blower discharge was bypassed around the combustion air heaters and blended with the hot air from the outlet of the heaters to achieve the desired primary air temperature for coal motivation.

The hot secondary air is feed directly to the wind box of the Riley Power burner package.

\section{Coal delivery system}

The coal delivery system is described above in section 3.c. Coal is delivered from the fuel hopper via the screw feeder and mixed with the primary air from the heaters. The primary air motives the coal into the Riley Power burner package.

4. Test results

Although the Riley Power air burner was specifically designed for the test facility packaged boiler, the packaged boiler was not originally designed for air/coal firing and therefore the physical size of the boiler imposed limitations on the operability of the burner/boiler system. Also there were system limitations which constrained the maximum operating range of the system. The maximum operating point for the test facility in air/coal service was $33 \mathrm{MMBtu} / \mathrm{hr}$ and the constraints were as following.

a. The air feed blower was operating at it maximum amperage draw.

b. The size of the flame produced at the burner encompassed the entire furnace side volume of the packaged boiler. The tip of the flame was very close or at the back tube wall of the boiler.

c. The flue gas pressure drop through the convective side of the boiler and discharge duct to the final bag house was very high such that the back 
pressure on the boiler housing was +5-6"WC and resulted in gas leakage from the boiler.

The Riley Power burner performed well with respect to flame stability, but, due to the small volume of the furnace section of the packaged boiler, it did not perform well with respect to particle burn out as measured by ash LOI. Given the small furnace volume and the large flame produced by the burner, there simply was not enough residence time in the furnace to achieve complete burn out of the coal particles. Ash LOI results from the air/coal testing came in at $25 \%$ to $30 \%$. Despite the poor LOI results, the air/coal testing did generate flame temperature and heat transfer data for comparison to high flame temperature oxy-coal combustion testing.

In air/natural gas combustion, the percentage of the heat duty released in the convective (back) pass was evaluated so as to compare the distribution of heat release in air vs. high flame temperature oxycombustion. It was shown for air/natural gas combustion that $40 \%$ of the heat release occurred in the convective pass. However, in air/coal combustion approximately $30 \%$ of the heat release occurs in the convective pass. This result is as expected due to the added heat release from burning coal particles in the radiant pass of the boiler.

The heat fluxes for combustion tests are calculated from chordal thermocouple assemblies installed in several of the boiler tubes. In industrial practice, chordal thermocouples are typically utilized to monitor changes in heat flux and temperature at the boiler tube walls. Since the actual physical placement of the thermocouples is difficult to control or measure in the manufacturing process, the use of industrial chordal thermocouples to measure absolute heat flux is not very accurate. Therefore, to address with this issue, the JOC and NETL team worked with Precision Measurement and Instrument Company (PMIC) to develop a procedure and test stand to calibrate the chordal thermocouples purchased from B\&W. This work significantly improved our ability to accurately measure heat flux in the radiant zone of test facility boiler, which is primarily representative of the flame irradiance at the boiler wall. 
5. CFD Model

Reaction Engineering International (REI) has completed a CFD model for the Riley Power air/coal burner in operation at the Hammond Test Facility. The CFD model represents the design operating case at $40 \mathrm{MBTU} / \mathrm{hr}$.

ii. Oxy-combustion

1. Burner development and history

a. First generation burner

The first generation oxy-coal burner designed and fabricated in cooperation with Maxon Corporation was a scaled up version of the oxy-coal burner used for the 2003 CRADA Study. The coal nozzle was simply a 6" diameter pipe with no vanes to direct the flow of coal. Primary oxygen was introduced at the end of the coal pipe via orifices located around the circumference of the coal pipe and angled toward the center of the coal flow to facilitate mixing of the coal and oxygen. Mixing of the primary oxygen and coal took place in an 8" diameter cup at the end of the coal pipe. Secondary or staged oxygen was introduced through ports in the burner block in a circumference around the 8" diameter cup which allowed the secondary oxygen to mix with the coal inside the furnace.

Although this burner configuration worked well for the CRADA Study, the burner rating for this project is a factor of 10 above that for the CRADA Study. For this size burner the primary oxygen did not have the ability to penetrate the 6" diameter stream of coal entering the furnace. The mixing of coal and oxygen was very poor which lead to burner instability. It was also believed that the 8" diameter cup where the coal and primary oxygen mixed was too small. Once ignition of the coal took place, the combustion gases generated in the cup could not escape into the furnace and therefore created a back pressure on the coal nozzle and inhibiting the free flow of coal into the burner. The burner instability was indicated by a very nonuniform flame, frequent flame out situations, and pressure pulsing of the furnace.

Another factor which also contributed to burner instability was the coal feed system. Pulverized 
coal was dried and blown with a hot air stream into an elevated coal hopper which allowed the motivating air to escape via a bag house and the coal collected in the hopper. Pulverized coal from the hopper was then transferred via a screw feeder into the coal feed pipe where the coal was picked up by recycled flue gas. It was intended to regulate the coal flow via the speed of the screw feeder. However it was quickly determined that the screw feeder was too large, and, at slow speeds, coal was being dumped into the feed pipe in an intermittent pattern which added to the pressure pulsing of the furnace. Also, at times, the coal would bridge inside the hopper and starve the screw feeder of coal.

b. Modified first generation burner

Based on preliminary test with the first generation burner, a series of modifications were tested to enhance coal/oxygen mixing and improve flame and furnace stability.

1. Install a 6" diameter sleeve in the burner cup to move the oxygen/coal mixing and the start of combustion out into the burner block. This would allow more volume and flow area for the generated combustion gases.

2. Install a $3 / 4$ " oxygen lance supplied by Maxon through the center of the coal feed pipe which served to put a small amount of primary oxygen in the center of the coal stream. This was intended to disperse and mix the coal with the major oxygen stream as a result of expansion of combustion gases at the center of the coal stream.

3. Installation of coal dispersing cones in the coal flow path as it entered the burner block. Various cones were installed with different angles and horizontal position in the burner block.

4. The secondary oxygen flow ports were configured with adjustable plugs to maintain the velocity of the secondary oxygen as the volume flow rate was adjusted.

5. In each configuration the intent was to match the velocity of the motive gas, 
primary oxygen, and secondary oxygen so as to allow contact between the coal and oxygen.

6. An eccentric orifice plate was added to the motive gas line just prior to the coal mixing point so as to swirl the motive gas and coal. The intent was that the swirling gas and coal would increase dispersion of the coal as it exited the coal feed pipe.

7. The existing coal screw feeder was replaced with a smaller diameter screw which would operate at higher speeds to deliver a more consistent flow of coal to the burner.

8. The bottom of the coal hopper was modified to allow a larger flow area at the entrance to the screw feeder so to minimize the chance for bridging in the hopper.

Throughout the burner development testing that followed the above modifications; the operation was evaluated for stability with the following parameters.

1. Visual flame was observed for brightness and consistency of brightness. Although visual evaluation is not a very quantitative approach it did allow the development to move to a point where a more quantitative approach could be utilized.

2. Excess oxygen required to maintain the flame and flame brightness. Also the excess oxygen was evaluated with respect to maintaining $\mathrm{CO}<200 \mathrm{ppm}$ in the flue gas.

3. Ash LOI content. Although the ash was not evaluated at each point along the way it was visually observed and as major improvements were made ash was collected and sent out for analysis to quantify our results.

4. Pressure pulsing of the boiler was used as a gauge for consistency in the combustion process.

5. Physical degradation of the burner components was monitored after each test run. The coal dispersing cones were 
particularly susceptible to degradation being directly in the combustion zone. Also impingement of the pilot burner was thought to play a role in cone degradation.

6. Total radiation output from sections of the flame was tracked for trends and oscillations.

7. Metal temperatures in the boiler were monitored for trends.

From December 2009 thru February 2010, a series of tests were conducted with the modified first generation burner. Pressure pulsing of the furnace and stability of the flame was greatly improved over earlier configurations of the burner. The tests were conducted at firing rates of 8 to 42 $\mathrm{MMBtu} / \mathrm{hr}$ and with various flue gas recycle rates. The primary parameter used to judge the performance of the burner was the ash LOI. Ash samples were collected during each run and analyzed by an independent lab. Figure 11 below shows the range of LOI achieved with the modified

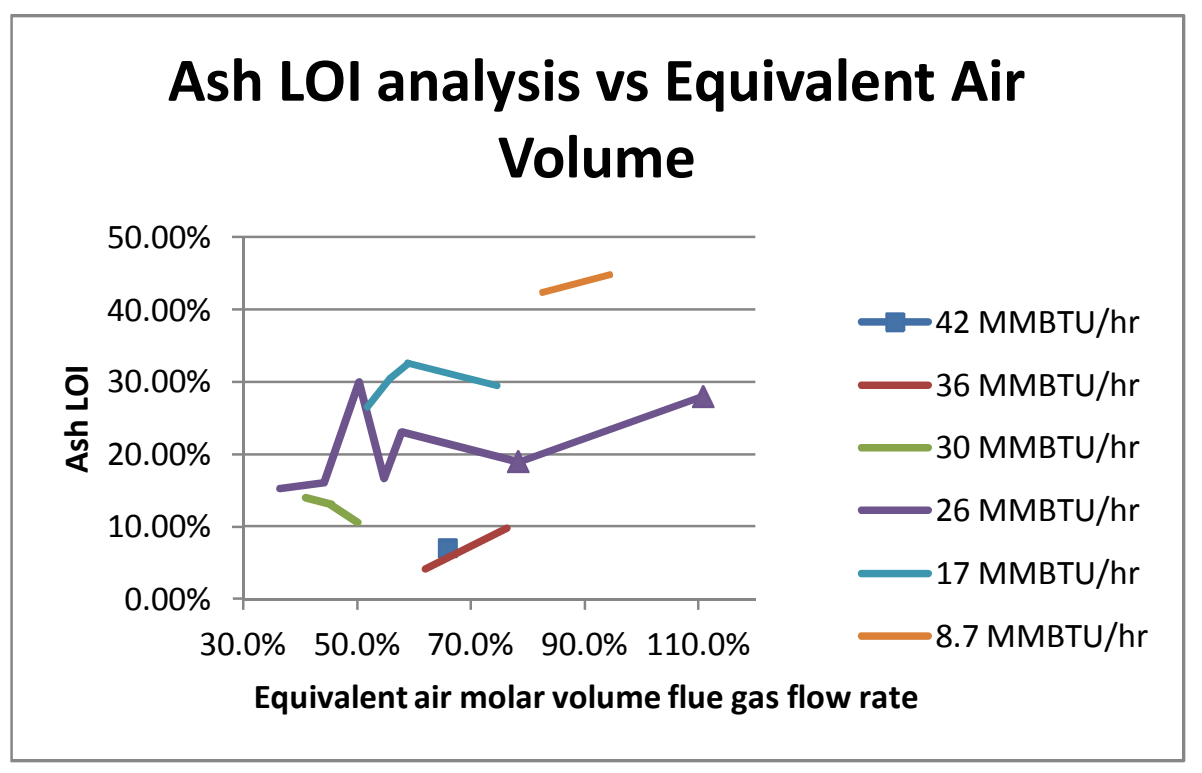

first generation burner.

Figure 11: Ash LOI results for the modified first generation burner 


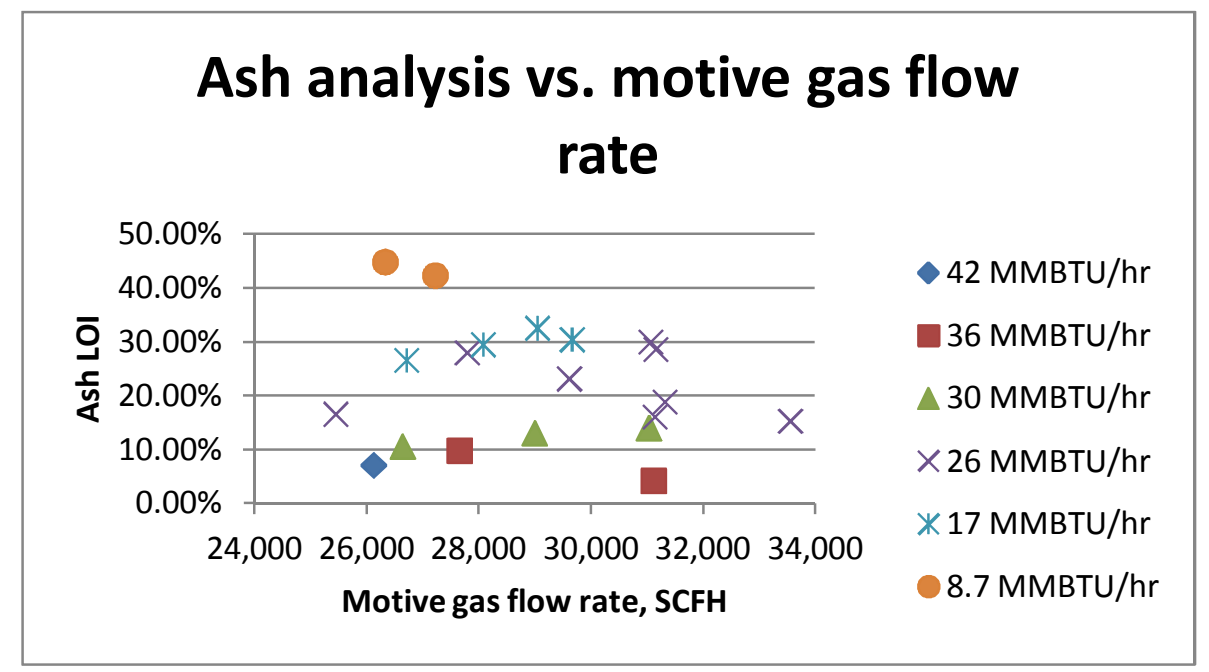

Figure 12: Ash LOI results for the modified first generation burner

As can be seen in the above figure 12 the best LOI performance was $5 \%$ which given $13 \%$ ash in the coal feed results in $1 \%$ loss of unburnt carbon. Although the burner showed significant improvement in LOI performance as the firing rate was increased, this improvement was not consistent. Also evaluating ash LOI vs. motive gas flow rate showed no correlation. These results indicated that oxygen and coal mixing at the burner still had room for improvement.

c. Oxygen swirl burner

Based on the previous test results discussed above, JOC and Maxon decided to modify the burner configuration such that the primary oxygen flow from the lance would be used to impart a swirl to the coal particles as they left the nozzle tip and allow for better mixing of the coal with secondary and tertiary oxygen. The burner configuration was modified as follows.

1. The coal dispersion cone and centerline oxygen lance where removed.

2. The oxygen lance line was modified so as to introduce primary oxygen to the coal feed pipe tangentially at one point. 
3. The primary oxygen supply line was modified so as to allow flow measurement of the primary oxygen.

On April 21, 2010 a series of tests were conducted with this new burner configuration. For these tests, the burner rating was kept fixed at $30 \mathrm{MMBTU} / \mathrm{hr}$ as a close to optimal burner rating without the concern of running at the equipment limits. The primary focus of these tests was to reduce the ash LOI by use of the oxygen swirl lance. After an initial test with no flow through the oxygen swirl lance to generate a performance base line, the oxygen swirl lance flow was held constant at the maximum flow available from the piping system (approximately $6 \%$ of the total oxygen flow). Additionally, the secondary oxygen flow rate was varied across several tests in order to minimize the ash LOI based on visual inspection of the ash during the testing. The visual inspection was followed up by laboratory testing of ash samples.

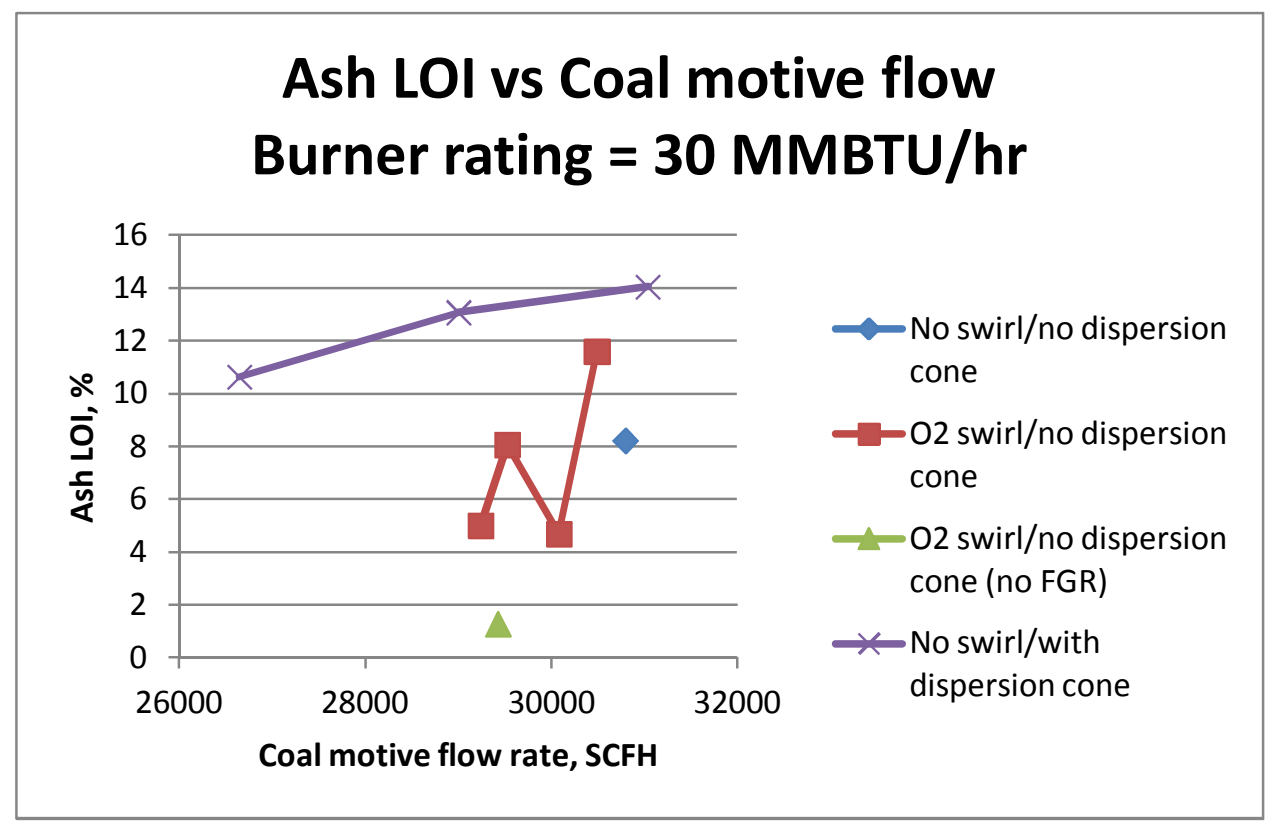

Figure 13: Ash LOI performance with oxygen swirl burner. 


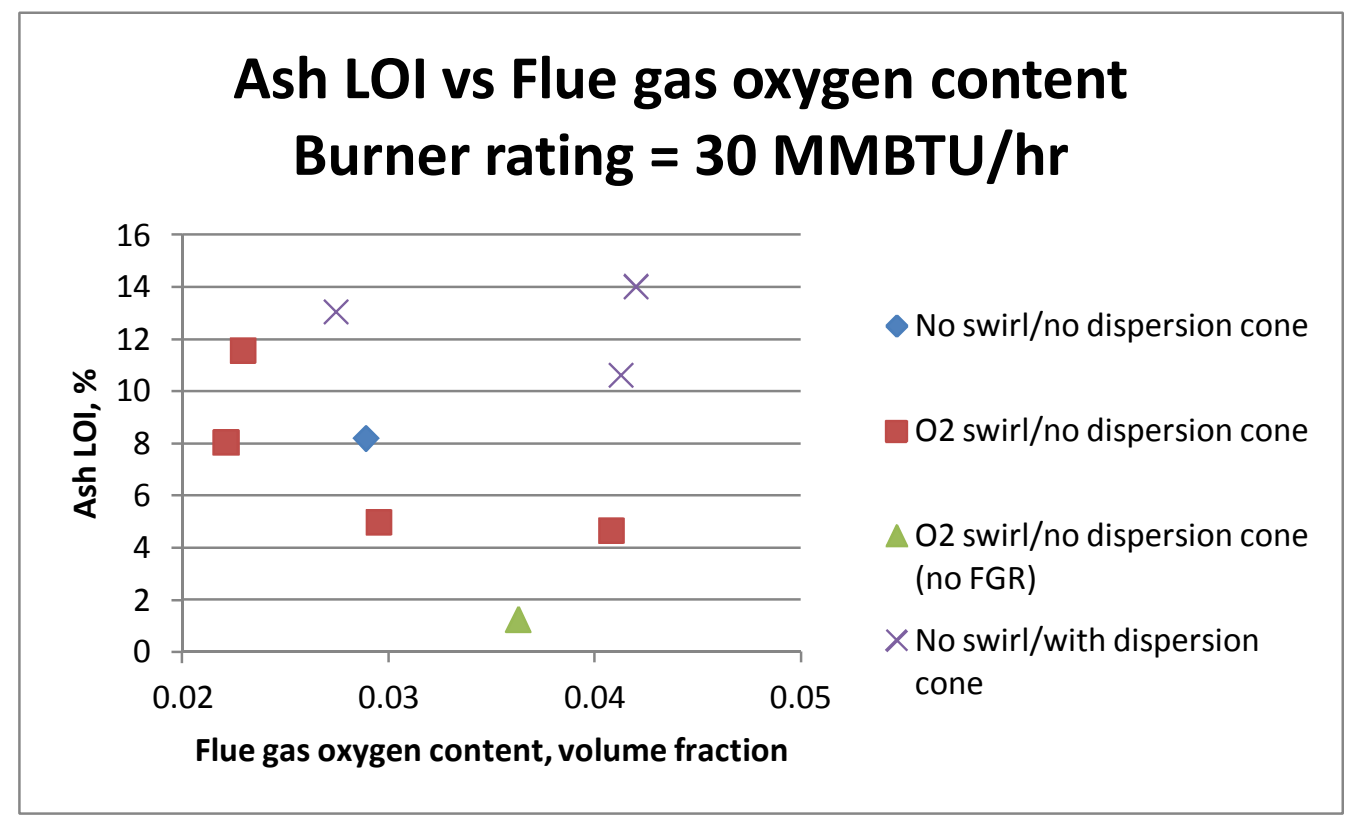

Figure 14: Ash LOI performance with oxygen swirl burner.

Figure 13 and 14 above shows a plot of the ash LOI as a function of motive gas flow rate and oxygen content in the flue gas. These plots do show that the new burner configuration with oxygen swirl lance did perform better than the burner with the fixed dispersion cone (modified first generation burner) in that, at any fixed motive gas flow rate or flue gas oxygen content, the ash LOI was reduced. These improvements with a single oxygen swirl nozzle lead to the design of the second generation with four tangential oxygen swirl nozzles equally spaced around the coal feed pipe.

d. Second generation burner

The Maxon second generation burner incorporated four tangential oxygen swirl nozzles and a bluff body in the center of the coal feed pipe to disperse the coal to the walls of the feed pipe. A CFD model for this burner configuration was produced by Reaction Engineering International. The burner was built and tested at the Hammond Test Facility in September 2011.

Although the design point for the second generation burner was $50 \mathrm{MMBtu} / \mathrm{hr}$, limitations in 
the steam condensing system prevented taking the burner up to the design point. Several test runs where conducted at burner capacities up to 41 $\mathrm{MMBTU} / \mathrm{hr}$.

In many ways the burner performed very well with respect to stability and ash LOI. However due to earlier issues with overheating in the burner throat, it was determined that the motive gas velocity needed to be increased in order to prevent ignition in the burner throat. The increased motive gas velocity and therefore volume of motive gas diluted the oxygen content at the burner nozzle. Therefore the flame temperature was below the goal.

e. Generation 2.1 burner

Since the predicted flame temperature with the higher required motive gas flow with the second generation burner was below the JOC target for this technology, burner modifications were made to reduce the throat diameter so as to increase the motive gas velocity without increasing the volume flow. In addition the burner was down sized to 40 MMBtu/hr in order to be able to operate the burner at optimal conditions. In addition, JOC also considered premixing some oxygen in the motive gas to enhance the oxygen mixing and raise the peak flame temperature. REI completed a CFD model of the new burner system. That model was then run with oxygen/motive gas premixing to determine potential benefits. The table 3 below is a summary of the model cases and inputs.

\begin{tabular}{|l|l|}
\hline Case3 & $\begin{array}{l}\text { Based on Hammond package boiler tests } \\
\text { conducted on 9/7/11 } \\
\text { Generation 2.0 Burner }\end{array}$ \\
\hline Case4 & $\begin{array}{l}40 \mathrm{MMBtu} / \mathrm{h} \text { Generation 2.1 Burner } \\
3.0 \% \mathrm{O}_{2} \text { in motive gas (100\% FGR as motive) }\end{array}$ \\
\hline Case5 & $\begin{array}{l}40 \mathrm{MMBtu} / \mathrm{h} \text { Generation 2.1 Burner } \\
10.0 \% \mathrm{O}_{2} \text { in motive gas }\end{array}$ \\
\hline Case6 & $\begin{array}{l}40 \mathrm{MMBtu} / \mathrm{h} \text { Generation 2.1 Burner } \\
20.0 \% \mathrm{O}_{2} \text { in motive gas }\end{array}$ \\
\hline
\end{tabular}

Table 3: REI modeling cases for generation 2.1 burner 
The results of the generation 2.1 model and the conclusions are summarized as follows.

1. The Generation 2.1 burner design leads to less stratified conditions at the coal nozzle exit than in previous designs

a. Cases $4-6$ are predicted to have higher peak temperatures and hotter overall conditions within the flame than Case3, which had similar operating conditions with the previous burner design

b. Broader and bushier flames in Cases 4 - 6 is indicative of more rapid mixing between $\mathrm{O}_{2}$ and fuel

c. Higher heat release rates near the front wall leads to a marked increase in heat transferred to surfaces closer to the burner and higher heat transfer rates overall

d. Percent of heat input lost in radiant section

1. Case $3=58.4 \%$

2. Case $4=68.6 \%$

3. Case $5=68.1 \%$

4. Case $6=67.4 \%$

2. Particle burnout and unburned carbon exiting on the fly ash are predicted to improve significantly compared to Case 3

a. Case3 Burnout $=98.4 \%$, UBC $=11.3 \%$

b. Case4 Burnout $=99.7 \%, \mathrm{UBC}=1.1 \%$

c. Case 5 Burnout $=99.6 \%$, UBC $=1.7 \%$

d. Case6 Burnout $=99.5 \%, \mathrm{UBC}=1.9 \%$

3. Variations to the amount of $\mathrm{O}_{2}$ premixing and the swirl imparted by the tangential $\mathrm{O}_{2}$ inlets impact flame behavior and local conditions within the flame. However, Cases $4-6$ are predicted to have similar conditions at the entrance to the screen tubes. The primary drivers for performance improvements in Cases $4-6$ are the design changes for the Generation 2.1 burner. Operating conditions show secondary effects on overall performance

4. Since model results show little or no benefit from premixing of oxygen with motive gas, further testing of the generation 2.1 burner did not include oxygen premixing so as to avoid potential operating safety issues. 
2. Final burner design description

Based on the test results of the second generation oxycoal burner and the modeling work described above for the Generation 2.1 Oxy-coal burner, the Generation 2.1 Oxy-coal burner became the final burner design for this project.

3. Test results with final burner

From July 2012 thru September 2012, a series of tests were conducted with the final burner design (Generation 2.1) as described above. The tests include variations in heat input, motive flow rate, and the ration of primary to secondary oxygen. Test 4 on 8/23/2012 was near the design point and test 1 and $2 A$ on 9/13/2012 were close comparison to air-coal combustion tests. Overall the burner and boiler performed well during these tests with the final burner design. However there were two instances went some burner degradation occurred. As in past test experience coal delivery issues persisted. At times variation in the coal delivery rate allowed coal to build up and combust at a slow rate in the burner feed pipe. The slow combustion of coal in the feed pipe is felt to be the cause of the burner degradation seen.

The test data does indicate a higher than expected amount of air in-leakage due to leaks on the suction of the recycle blower which was the lowest operating pressure in the system. Note that the NOx levels in the flue gas analysis are also higher than expected. The high NOx is most likely a result of the air in-leakage.

4. Flame temperature measurements with final burner Flame color temperature determination was performed using a modified "two-color method" that utilized four $10 \mathrm{~nm}$ wide spectral bands centered about the 4 wavelength values in the following table.

Wavelengths utilized in the Flame Temperature Analysis

$\begin{array}{llll}\text { Wavelength } 1 & \text { Wavelength } 2 & \text { Wavelength } 3 & \text { Wavelength } 4\end{array}$

$540 \mathrm{~nm}$

$660 \mathrm{~nm}$

$750 \mathrm{~nm}$

$850 \mathrm{~nm}$

Table 4: Wavelengths utilized in the Flame Temperature Analysis 
The wavelengths were chosen so as to provide uniform color temperature results through the analysis color temperature range. The use of bands centered at $550 \mathrm{~nm}$ and $650 \mathrm{~nm}$ was avoided due to the proximity of nearby elemental emissions.

Each of the four wavelength bands were paired with one another, which yielded a total of 6 different wavelength pairs. An approximate solution to solve for temperature from Wien's formula was utilized, as shown in the following equation.

$$
\text { Flame Color Temperature }=\frac{C 2\left(\frac{1}{\lambda_{1}}-\frac{1}{\lambda_{2}}\right)}{\ln \left(E_{1} \lambda_{1}^{5}\right)-\ln \left(E_{2} \lambda_{2}{ }^{5}\right)}
$$

In this equation, C2 is a constant, lambda 1 and 2 are the wavelength values for a pair, and $E_{1}$ and $E_{2}$ are the measured irradiance values acquired by the spectrometer for the respective wavelength values. So for each spectrometer scan, 6 solutions for the flame temperature were calculated, and these temperatures were averaged to yield an average flame color temperature (AFCT).

The spectrometers measure the light emissions from particles that exist within a cone that extends from the instrument at the port wall to a circle at the burner center line which is 8.75 " in diameter. However, it is not thought that the instrument can "see through" the flame to that center line. The exact location of the flame color temperature results is ill-defined as it depends on the flame shape and particle density within the cone which are unknowns. Further, the temperature solution is both weighted toward particles that are closer to the instrument as well as weighted toward emissions received from higher temperature particles. The net effect of these competing effects is not possible to ascertain without making a number of assumptions.

\begin{tabular}{cccccc} 
Test date & & $8 / 23 / 2012$ & $8 / 23 / 2012$ & $9 / 13 / 2012$ & $9 / 13 / 2012$ \\
Test \# & 1 & 4 & 1 & $2 \mathrm{~A}$ \\
\hline Port 4 Color Temperature & $\mathrm{nm}$ to $\mathrm{nm}$ & 540 to & 540 to & 540 to & 540 to \\
Range & & 850 & 850 & 850 & 850 \\
Port 4 Maximum & Degrees & 2713 & 3739 & 3562 & 3662 \\
Flame Color Temperature & $\mathrm{F}$ & & & &
\end{tabular}




\begin{tabular}{|c|c|c|c|c|c|}
\hline $\begin{array}{c}\text { Port } 4 \text { Average Flame Color } \\
\text { Temperature (AFCT) }\end{array}$ & $\begin{array}{l}\text { Degrees } \\
\mathrm{F}\end{array}$ & 2580 & 3335 & 3269 & 3351 \\
\hline $\begin{array}{c}\text { Port } 4 \text { Minimum Flame Color } \\
\text { Temperature }\end{array}$ & $\begin{array}{l}\text { Degrees } \\
\mathrm{F}\end{array}$ & 2465 & 3068 & 3055 & 3143 \\
\hline $\begin{array}{l}\text { Port } 4 \text { Color Temperature } \\
\text { Linear Fit Slope }\end{array}$ & $\begin{array}{l}\text { Degrees } \\
\mathrm{F} / \mathrm{nm}\end{array}$ & -1.27 & -3.45 & -2.60 & -2.68 \\
\hline $\begin{array}{c}\text { Port } 4 \mathrm{R}^{\wedge} 2 \text { of Color } \\
\text { Temperature Linear Fit }\end{array}$ & $\mathrm{N} / \mathrm{A}$ & 0.96 & 0.90 & 0.92 & 0.90 \\
\hline $\begin{array}{l}\text { Port } 4 \text { Temporal Standard } \\
\text { Deviation of AFCT } \\
\text { Table 5: Test results flame }\end{array}$ & $\begin{array}{l}\text { Degrees } \\
F \\
\text { mperature }\end{array}$ & 38 & $t$ port 0 & 143 & 161 \\
\hline $\begin{array}{l}\text { Test date } \\
\text { Test \# }\end{array}$ & & $\begin{array}{c}8 / 23 / 2012 \\
1\end{array}$ & $\begin{array}{c}8 / 23 / 2012 \\
4\end{array}$ & $\begin{array}{c}9 / 13 / 2012 \\
1\end{array}$ & $\begin{array}{c}9 / 13 / 2012 \\
2 \mathrm{~A}\end{array}$ \\
\hline $\begin{array}{c}\text { Port } 0 \text { Color Temperature } \\
\text { Range }\end{array}$ & $\mathrm{nm}$ to $\mathrm{nm}$ & $\begin{array}{l}540 \text { to } \\
850\end{array}$ & 540 to 850 & $\begin{array}{l}540 \text { to } \\
850\end{array}$ & $\begin{array}{l}540 \text { to } \\
850\end{array}$ \\
\hline $\begin{array}{l}\text { Port } 0 \text { Maximum } \\
\text { Flame Color Temperature }\end{array}$ & $\begin{array}{l}\text { Degrees } \\
\mathrm{F}\end{array}$ & 3942 & 4412 & 4477 & 4420 \\
\hline $\begin{array}{c}\text { Port } 0 \text { Average Flame Color } \\
\text { Temperature (AFCT) }\end{array}$ & $\begin{array}{l}\text { Degrees } \\
\mathrm{F}\end{array}$ & 3609 & 3937 & 3927 & 3905 \\
\hline $\begin{array}{c}\text { Port } 0 \text { Minimum Flame Color } \\
\text { Temperature }\end{array}$ & $\begin{array}{l}\text { Degrees } \\
\text { F }\end{array}$ & 3347 & 3567 & 3484 & 3484 \\
\hline $\begin{array}{l}\text { Port } 0 \text { Color Temperature } \\
\text { Linear Fit Slope }\end{array}$ & $\begin{array}{l}\text { Degrees } \\
\text { F/nm }\end{array}$ & -3.05 & -4.32 & -5.06 & -4.77 \\
\hline $\begin{array}{c}\text { Port } 0 \mathrm{R}^{\wedge} 2 \text { of Color } \\
\text { Temperature Linear Fit }\end{array}$ & $\mathrm{N} / \mathrm{A}$ & 0.94 & 0.95 & 0.96 & 0.96 \\
\hline $\begin{array}{c}\text { Port } 0 \text { Temporal Standard } \\
\text { Deviation of AFCT }\end{array}$ & $\begin{array}{l}\text { Degrees } \\
\mathrm{F}\end{array}$ & 90 & 66 & 84 & 87 \\
\hline
\end{tabular}

Table 6: Test results flame temperature measurement port 4

The explanation of the terms utilized in the flame temperature result tables are as follows. The color temperature range listed is the instrument wavelength range utilized in the flame temperature analysis. The maximum flame color temperature is the time averaged temperature result for the 2-color flame temperature calculation in this range which yielded the highest temperature, and conversely the minimum is the time averaged result for the minimum temperature. The average flame color temperature is the average of all 6 of the flame temperature results obtained for this wavelength range. Over the wavelength range utilized, it is expected that the temperature results will be dependent on wavelength such that longer wavelengths yield lower temperatures and shorter wavelengths yield higher temperature results. This effect is expected based on the fact that the flame is not a single uniform 
temperature, ie radiant energy is reaching the instrument from particles that are emitting at a plethora of temperatures. To quantity this effect, an average wavelength was determined for each 2-color pair and the resultant temperature versus wavelength data fit to a line. This is given as the color temperature linear fit slope, and associated $\mathrm{R}^{\wedge} 2$ of this fit. A negative slope is the expected result based on theory, with the slope becoming more negative as the variation in particle temperatures increases, and/or the spatial gradient of flame temperature within view of the instrument increases.

A strong negative value to the slope with a high $\mathrm{R}^{\wedge} 2$ value indicates the presence of particles that are both above and below the minimum and maximum temperatures listed in the table. This is true for the "design" cases above, indicating the likelihood of particles at temperatures above the listed maximums.

For all cases, the relatively good $\mathrm{R}^{\wedge} 2$ values show that the reported AFCT will represent a color temperature at approximately $695 \mathrm{~nm}$. $695 \mathrm{nmn}$ is the average value for the wavelength range utilized. Determination of color temperatures at other wavelengths can be made with the linear slope provided, though extrapolation of results outside of the color range utilized maybe problematic. The purpose of providing wavelength dependent color temperatures is to provide a means to compare to other data.

As expected, the flame is significantly cooler at port 4 , which is 8.75 feet downstream of the burner throat. Port 0 is approximately 0.5 feet downstream of the burner throat. The maximum observed temperature is significantly lower downstream, and there is less variation in temperature observed downstream. This is consistent with results modeled by REI. Overall, the temporal standard deviation of the AFCT is low for all cases, indicating the process was fairly steady in terms of flame temperature during the evaluation period. It is notable that the temporal standard deviation is highest for the port 4 design cases. However, some of this may be explained by slagging on the interior wall that occurred near this port. Observations made subsequent to those test days indicated slag "closing off" the front of the port 4 which limited the view. In general a smaller view will increase the temporal standard deviation both 
due to lower signal hitting the spectrometer, as well as creation of a smaller "view cone" which would make the reading more sensitive to local variation within the flame. The 8-23 test 1 point was earlier in the day, likely before slag build-up.

The spectral irradiance data acquired is unique and could be used to inform future studies. This is primarily because, to the authors' knowledge, the experiments conducted at JOC resulted in the highest temperature oxy-coal flame within a pilot scale boiler achieved to date. The irradiance spectrum from the high temperature flame was found to differ from spectrums emitted from cooler flames in a manner that led to developing a modified analysis procedure. The need for this adaption is attributed to large particle temperature variations in the flame front region. To determine temperature from the emission data, a soot based approach was utilized using Wien's formula. Typically, this method utilizes two discreet spectral bands such as in the so called twocolor method, or a regression technique to fit emission data to Wien's formula across a broad wavelength region. In either case, a single temperature is reported as a flame temperature. In the 2012 JOC high temperature oxy-coal flame data, a single reported flame temperature was found to be inadequate as the temperature result was significantly dependent on the wavelengths chosen in implementation of the two-color method. Hence, an improved analysis technique was realized for flame temperature reporting in which the temperature results are reported as wavelength dependent "flame color temperatures". This reporting method should allow for robust comparison to other experimental results, for example that might be obtained in future studies.

5. CFD model results with final burner

From 12, a series of tests were conducted as described above.

The July 2012 thru September 2012 test cases with the final burner design (Generation 2.1) were also modeled with CFD software by Reaction Engineering International. In addition REI modeled test 4 (near the design point) with air in-leakage removed, the pilot duty removed, and excess oxygen in the flue gas fixed at $3.0 \%$. This case labeled case 9 (figure 15) is representative of ideal 
design operating conditions. Figure 15 below shows the axial temperature profile from the REI model. These results show that flame temperatures in excess of $4500^{\circ} \mathrm{F}$ are expected in the first six feet from the burner wall. Note that there is a slight delay in reaching peak temperature in Case 9 compared to Cases 8, 10, and 11. This is due to the fact that the pilot is not in operation in Case 9. Also note the higher peak temperatures in Cases 8,10 , and 11 than in case 9 due to oxy gas combustion from the pilot. However even without the pilot (case 9), the expected flame temperature is above $4500^{\circ} \mathrm{F}$ for the first six feet of the boiler.

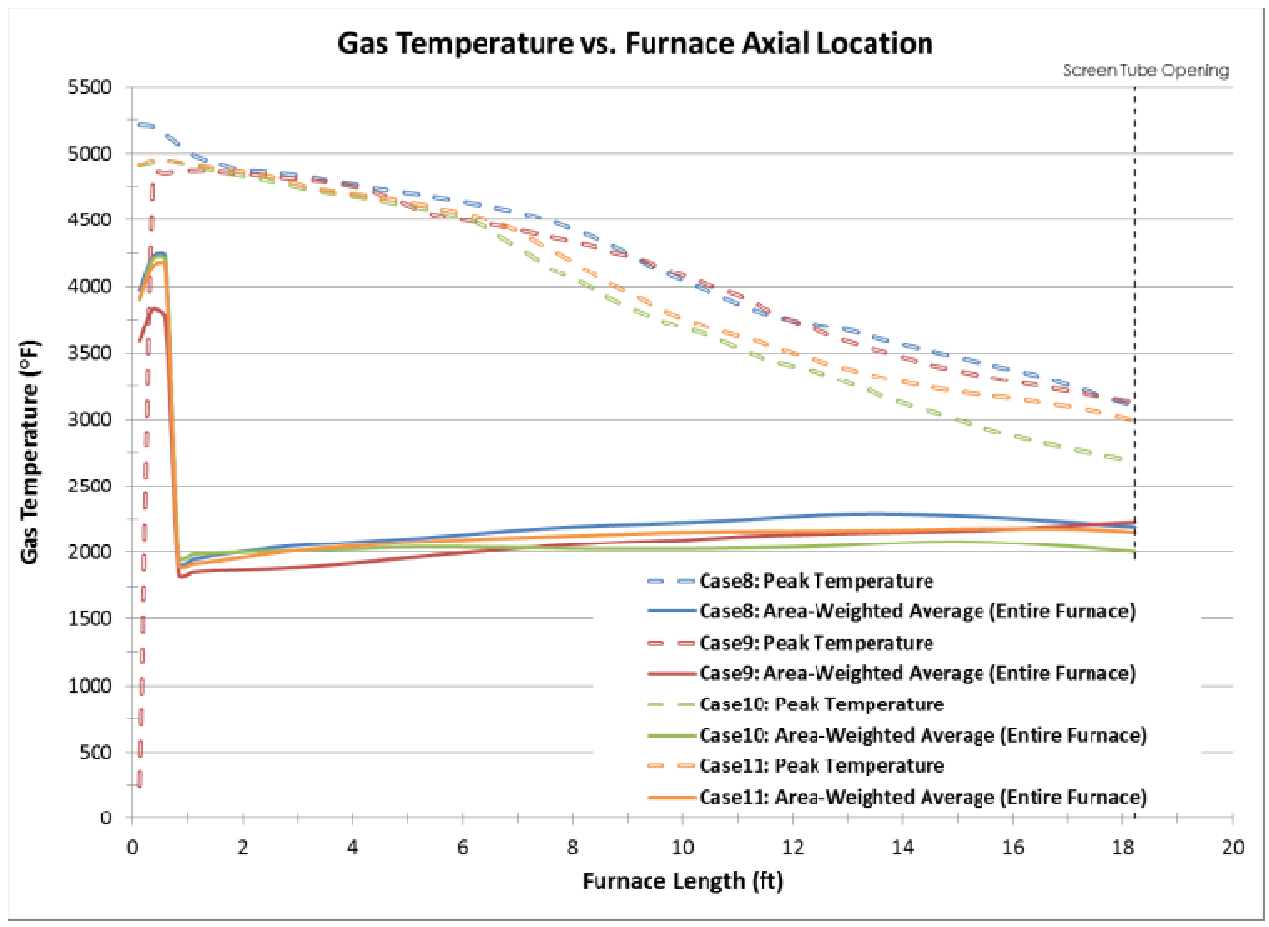

Figure 15: Reaction Engineering CFD model axial temperature profile - area weighted and peak temperatures.

Reaction engineering also modeled the air-coal combustion burner performance in the test boiler and an ideal high flame temperature oxy-coal combustion operating point (REI Case 9).

At similar firing rates the results show a peak flame temperature of $4867^{\circ} \mathrm{F}$ for high flame temperature oxycoal combustion compared to $3250^{\circ} \mathrm{F}$ for air coal combustion. The results also show a 1.6 percentage 
point improvement in particle burnout for high flame temperature oxy-coal combustion. The high flame temperature oxy-coal combustion also shows for the test boiler a significant reduction in unburnt carbon in the fly ash which is proportional to ash LOI. Note that this unburnt carbon result is influenced by the fact that the test boiler had a very small volume for air-coal combustion.

6. Comparison of flame temperature measurement and CFD models

The oxy-combustion high flame temperature was determined by two modalities using test data. Reaction Engineering International did CFD modeling of the actual test conditions from test \#4 on 8/23/12. Figure 16 shows a radial temperature plot 6 inches from the burner wall where the flame temperature exceeded $4500 \mathrm{~F}$ for oxycoal firing.



Figure 16: Reaction Engineering CFD model results for the 8/23/2012 test \#4. Radial temperature plot

The NETL project team used a Spectrometer mounted on the boiler east wall which is also 6" from the burner wall and reads data from moving particles part way into the 
flame but not all the way into the burner centerline. The NETL Spectrometer Flame Temperature Determination Graph (Figure 17) for a 12 second average flame temperature indicates a temperature of $3950^{\circ} \mathrm{F}$ with some readings varying $+/-200^{\circ} \mathrm{F}$. The REI graph above (Figure 16, 6" from the burner wall) shows a flame temperature of approximately $4000^{\circ} \mathrm{F}$ at a distance of approximately 0.6 feet radially from the burner centerline. This distance from the centerline reflected in the REI model is within the NETL project team's estimate for the instrumentation's penetration into the flame.



Figure 17: CCD Spectrometer flame temperature determination at port 0, August 23, 2012, JOC test \#4

7. Slagging study in oxy-combustion

a. Methods and results

JOC collected slag samples from the boiler tube walls at numerous points down the length of the furnace section of the boiler. Samples were collected after several one day run times in oxycombustion service and after the unit had cooled down slowly so as not to disturb the slag. In addition JOC collected fly ash samples during the 
high flame temperature oxy-combustion test runs. The slag and ash samples were sent to Coal Combustion Inc. for evaluation and spectroscopic analysis. In addition Coal Combustion sent a portion of each sample to SGS Minerals for chemical and physical property analysis. The final report from Coal Combustion, Inc which includes analysis results and an evaluation of the slagging properties and tendencies of oxy-combustion vs. typical air fired units based on these results.

\section{b. Conclusions}

The $\mathrm{CCl}$ report indicated that the fuels utilized during the test firing of the oxy-combustion test boiler in July and August 2012 was a high slagging potential Illinois Basin high sulfur coal. When firing this fuel in the oxy-combustion test boiler, the slag tended towards a more fused molten drippy material.

Burns and Roe examined the report and data, and concluded that industry research indicates that the slagging and fouling characteristics of an oxycombustion fuel boiler should approximate that of the same boiler when combusting the identical coal with air firing. Although there is some change to the ash mineralogy with oxy-combustion, this variation is not considered to be of significance. Thus, the slagging and fouling characteristics of a typical $300 \mathrm{MW}$ air-blown boiler retrofitted to oxycombustion should be nearly identical for the same coal. A model was prepared using a representation washed Illinois basin No. 6 seam coal. With high flame temperature oxycombustion boilers using high recirculation ratios to balance heat transfer, slagging and fouling characteristics for the oxy fueled fired configuration should be relatively identical to that of air fired. The possibility does exist that furnace wall temperatures in the burner zone might be slightly higher under oxy-fuel firing than air firing, and therefore the potential for wet wall slag is increased especially for low fusion temperature coals. These types of scenarios have been encountered in air fired boilers where the furnace heat release to plan area approaches 2.0 MMBtu 
per square foot. If required in a high flame temperature oxy-coal retrofit, then standard industry measures should be utilized to handle wet slag.

c. IPR system testing

i. Flue gas purification and carbon capture results

The gas entering IPR had the same composition as the flue gas recycle (FGR) - primarily $\mathrm{CO}_{2}, \mathrm{H}_{2} \mathrm{O}, \mathrm{O}_{2}, \mathrm{~N}_{2}$ and Ar. The oxygen comes from any excess $\mathrm{O}_{2}$ above that required for complete combustion. Nitrogen can come from the coal, any leaks into the system, or from impurities in the incoming $\mathrm{O}_{2}$. There were also small amounts of $\mathrm{SO}_{\mathrm{x}}, \mathrm{NO}_{\mathrm{x}}, \mathrm{HCl}$ and $\mathrm{CO}$. These are dependent on the coal composition $\left(\mathrm{SO}_{\mathrm{x}}, \mathrm{HCl}\right)$ and the firing conditions $\left(\mathrm{O}_{2}\right.$, $\mathrm{CO}$, and $\left.\mathrm{NO}_{\mathrm{x}}\right)$. Table 7 , below, shows some of the results obtained at Jupiter along with a comparison to an ASPEN model of this installation (detailed later in this report).

\begin{tabular}{|c|c|c|c|c|c|c|c|c|c|}
\hline & \multicolumn{2}{|c|}{ FGR output } & \multicolumn{2}{|c|}{$\begin{array}{l}\text { Tower } \\
\text { output }\end{array}$} & \multicolumn{2}{|c|}{$\begin{array}{l}12 \text { atm } \\
\text { output }\end{array}$} & \multicolumn{2}{|c|}{$\begin{array}{c}136 \text { atm (final) } \\
\text { output }\end{array}$} \\
\hline & & Field & Model & Field & Model & Field & Model & Field & Model \\
\hline $\mathrm{CO}_{2}$ & $\%$ & 55.5 & 56.0 & 79.4 & 73.5 & 75.7 & 81. & & 83. \\
\hline $\mathrm{H}_{2} \mathrm{O}$ & $\%$ & 29.9 & 32.7 & 5.5 & 11.2 & 0.13 & 1.70 & .38 & .03 \\
\hline $\mathrm{O}_{2}$ & $\%$ & 7.0 & 3.2 & 4.35 & 4.8 & 5.1 & 5.2 & & 5.4 \\
\hline $\begin{array}{c}\mathrm{N}_{2}+ \\
\mathrm{Ar}\end{array}$ & $\%$ & & 6.78 & & 10.2 & & 5.85 & & 5.85 \\
\hline $\mathrm{SO}_{2}$ & ppm & 9150 & 9900 & 285 & 64.3 & 59 & 0.0 & 10 & 0.0 \\
\hline $\mathrm{NO}_{2}$ & ppm & .77 & 3.0 & & 1.6 & 9.56 & 0.0 & 541 & 0.0 \\
\hline NO & ppm & 1070 & 560 & 907 & 669 & 447 & 0.0 & 134 & 0.0 \\
\hline $\mathrm{N}_{2} \mathrm{O}$ & ppm & 84.6 & 90. & 1.47 & 125 & 13.4 & 0.0 & 113 & 0.0 \\
\hline $\mathrm{CO}$ & $\mathrm{ppm}$ & 86 & 300 & 1000 & 450 & 886 & 0.0 & 260 & 0.0 \\
\hline $\mathrm{HCl}$ & $\mathrm{ppm}$ & 38 & 300 & 6.8 & 73.6 & .34 & 1.05 & 10 & .05 \\
\hline
\end{tabular}

Table 7: Hammond Test Facility and ASPEN IPR-composition results compared

The Jupiter installation of IPR took a slipstream from the FGR. This passed through a counter-current wet scrubber or tower. The gas then underwent 4 stages of compression to 3, 12, 40, and 136 atm. After each stage of compression, the gas was cooled and the heat recovered. This cooling also condensed 
water, which was recovered and analyzed. The system included sample ports after each pressurization stage to allow measurement of the gas composition. Most gas measurements were taken with an FTIR. The FTIR was capable of measuring the gas composition in real time. However, the FTIR technique could not measure $\mathrm{Ar}, \mathrm{N}_{2}$, or $\mathrm{O}_{2}$. This FTIR was equipped with a separate oxygen sensor. Because of this limitation, there were no IPR-measured numbers for $\mathrm{N}_{2}$ or $\mathrm{Ar}$, and the sum of $\mathrm{N}_{2}+\mathrm{Ar}$ was be estimated by difference. Estimation by difference is not ideal, since one parameter of interest is the rate of air infiltration into the boiler/IPR system at points where system pressure is below ambient pressure. Infiltration dilutes the process stream and may also contribute to the amount of NOx produced. A GC was employed at the end of FY11 measure nitrogen explicitly in future tests at the Hammond Test Facility.

In IPR, as the gas passes through the process, most of the soluble gasses are removed in the condensed water. The resulting gas leaving IPR is thus principally $\mathrm{CO}_{2}, \mathrm{O}_{2}, \mathrm{~N}_{2}$, and $\mathrm{Ar}$. Most of the water and $\mathrm{SO}_{2}$ are removed in the tower. The gas is saturated leaving the tower and following each cooling step. Thus the amount of water in the gas leaving the system will be thermodynamically determined by the temperature and pressure of the gas leaving the system.

The original design of IPR included spray-cooling after each stage of compression. However, for the slipstream system, economic and time considerations limited the spray-cooling to the entering tower that operates at approximately atmospheric pressure. Subsequent, higher pressure condensers were simple tube-in-tube heat exchangers. The initial heat exchange step using the spray tower reduced the water content from $\sim 30 \%$ to $5.5 \%, \mathrm{SO}_{2}$ from $>9100 \mathrm{ppm}$ to $<300 \mathrm{ppm}$, and $\mathrm{HCl}$ from $\sim 40$ $\mathrm{ppm}$ to $<10 \mathrm{ppm}$. The situation with nitrogen is more complex, but those levels are also reduced. The gas leaving the system contained $0.4 \%$ water and approximately $10 \mathrm{ppm} \mathrm{SO}$ and $\mathrm{HCl}$. If spray-cooling had been used in the higher pressure stages, the concentration of the soluble gasses would probably be lower.

The removal of the oxides of nitrogen and sulfur is more complex than simply dissolving those materials in the forms in which they enter IPR. As the pressure increases and in the presence of the excess oxygen, $\mathrm{SO}_{2}$ will be oxidized to $\mathrm{SO}_{3}$, which is more soluble. This reaction is, however, known to be slow. Similarly, the oxides of nitrogen should move towards more $\mathrm{NO}_{2}$ and less $\mathrm{NO}$ and $\mathrm{N}_{2} \mathrm{O}$ as pressure increases. This is, 
in fact, what is seen in the gas analysis. However, the chemistry is more complex than this because $\mathrm{NO}_{2}$ and $\mathrm{SO}_{2}$ interact, as seen in the following equations from the old lead chamber process used to produce sulfuric acid.

$$
\begin{aligned}
& 2 \mathrm{NO}_{2}+\mathrm{H}_{2} \mathrm{O} \rightarrow \mathrm{HNO}_{2}+\mathrm{HNO}_{3} \\
& \mathrm{SO}_{2}+\mathrm{HNO}_{3} \rightarrow \mathrm{NOHSO}_{4} \\
& \mathrm{NOHSO}_{4}+\mathrm{HNO}_{2} \rightarrow \mathrm{H}_{2} \mathrm{SO}_{4}+\mathrm{NO}_{2}+\mathrm{NO} \\
& \mathrm{SO}_{2}(\mathrm{aq})+2 \mathrm{HNO}_{2} \rightarrow \mathrm{H}_{2} \mathrm{SO}_{4}+2 \mathrm{NO} \\
& \text { Overall } \\
& \mathrm{NO}_{2}+\mathrm{H}_{2} \mathrm{O}+\mathrm{SO}_{2}(\mathrm{aq})=\mathrm{H}_{2} \mathrm{SO}_{4}+\mathrm{NO}
\end{aligned}
$$

Completing the cycle

$2 \mathrm{NO}+\mathrm{O}_{2} \rightarrow 2 \mathrm{NO}_{2}$

Increasing pressure will further push this reaction to $\mathrm{NO}_{2}$.

It is believed that, as long as $\mathrm{SO}_{2}$ absorption is active, only small amounts of $\mathrm{NO}_{x}$ will be absorbed. Gas composition measurements, comparing incoming gas to captured gas, show a large change in $\mathrm{SO}_{2}$ content, but not a large change in $\mathrm{NOx}$ content. The sum of all nitrogen compounds appears to remain unchanged. Note, however, the number of tests at the higher pressure portions of IPR is limited and sampling-pressure in these sections was variable - which can skew composition results. An improvement in the studied system would include actively spraying wet heat exchangers at pressure. Active spray is included in the original design of IPR. This increased interaction between solvent and solute is expected to remove more of the $\mathrm{NO}_{\mathrm{x}}$.

ii. Modeling the slip stream

As detailed by Harendra et al (Harendra, S., Oryshchyn, D., Ochs, T., Gerdemann, S., Clark, J., Modeling and Simulation of Integrated Pollutant Removal (IPR) Systems using ASPEN Plus 2012), an ASPEN model of the Hammond Pest Facility IPR process was built to allow workers to examine effects of system perturbations. In this way, changes aimed at optimizing IPR efficiency and heat recovery can be related to predicted changes in the composition of processed flue-gas. Using this model as a base, we can also examine changes resulting from changes in the scale of the system.

ASPEN models of the system used average concentrations of material from field tests as input for the model: $32.8 \% \mathrm{H}_{2} \mathrm{O}$, $56.1 \% \mathrm{CO}_{2}, 3.2 \% \mathrm{O}_{2}, 5.8 \% \mathrm{~N}_{2}$, around $1 \% \mathrm{SO}_{2}$, and other trace 
compounds such as $\mathrm{NO}_{2}, \mathrm{NO}, \mathrm{N}_{2} \mathrm{O}, \mathrm{CO}$, and $\mathrm{HCl}$. The modeled results using the concentrations listed above showed that-

- IPR should be effective in reducing the gaseous sulfur compounds $\left(\mathrm{SO}_{x}\right.$ ) from $9,920 \mathrm{ppm}$ to zero.

- IPR should be effective in removing nitrogen compounds such as $\mathrm{NO}_{2}, \mathrm{NO}$ and $\mathrm{N}_{2} \mathrm{O}$.

- IPR should be effective in removing the majority of the water from the resultant oxy-coal gas product stream, from $32.8 \%$ to $0.0001 \%$ or less.

- IPR should be effective in removing most of the remaining trace compounds, such as $\mathrm{HCl}, \mathrm{CO}, \mathrm{H}_{2} \mathrm{~S}$, and $\mathrm{Cl}_{2}$ (which were removed with the water).

The resulting product at the final stage was concentrated $\mathrm{CO}_{2}$ including tramp "permanent" gases as follows.

$\begin{array}{ll}\mathrm{CO}_{2} & 89 \% \\ \mathrm{O}_{2} & 4.34 \% \\ \mathrm{~N}_{2}+\mathrm{Ar} & 6.85 \% \\ \mathrm{CO} & 600 \mathrm{ppm} \\ \mathrm{H}_{2} \mathrm{O} & 600 \mathrm{ppm} \\ \mathrm{SO}_{2} & 30 \mathrm{ppm} \\ \mathrm{NO}_{2} & \text { nil } \\ \mathrm{NO} & \text { nil } \\ \mathrm{N}_{2} \mathrm{O} & 50 \mathrm{ppm} \\ \mathrm{HCl} & \text { nil }\end{array}$

Although definitive guidelines or regulations for sequestration or enhanced oil recovery purity requirements do not exist at this time, the $\mathrm{CO}_{2}$ content of the above final IPR product can be further enhanced by distillation to meet nearly any purity requirement. The remaining major impurities $\left(\mathrm{O}_{2}, \mathrm{~N}_{2}, \mathrm{Ar}\right.$, and CO) all have normal boiling points far below that of $\mathrm{CO}_{2}$ therefore are easily removed by distillation as is currently practiced in most food grade $\mathrm{CO}_{2}$ applications. The energy requirement and $\mathrm{CO}_{2}$ recovery from the distillation process is a function of the final purity requirements for the $\mathrm{CO}_{2}$ product.

Though not measured in the field, the fate of $\mathrm{Hg}$ in IPR was modeled using the ASPEN model, assuming a high initial concentration at the inlet of IPR system of $10 \mathrm{ppm}$. There was a reduction of more than 5 magnitudes of order of $\mathrm{Hg}$ concentration in the flue gas stream after absorption tower and most of them knocked down into the water at the tower. There was nearly zero $\mathrm{Hg}$ concentration found at the third and fourth stage of IPR system in the gas stream. Basically, the elemental mercury from the gas stream was reacted with oxidizing components and converted to soluble mercury compounds such as $\mathrm{HgCl}_{2}$. During the IPR water treatment, more than $85 \%$ of 
Hg was removed at the coagulation and flocculation process. The sludge produced during this process consists of removed $\mathrm{Hg}$. The chart below shows the system-fates $\mathrm{Hg}$ in IPR. Since $\mathrm{Hg}$ has not been measured in the gas stream of the IPR system installed at the Hammond Pest Facility, results are taken from the ASPEN model of the installed system. 


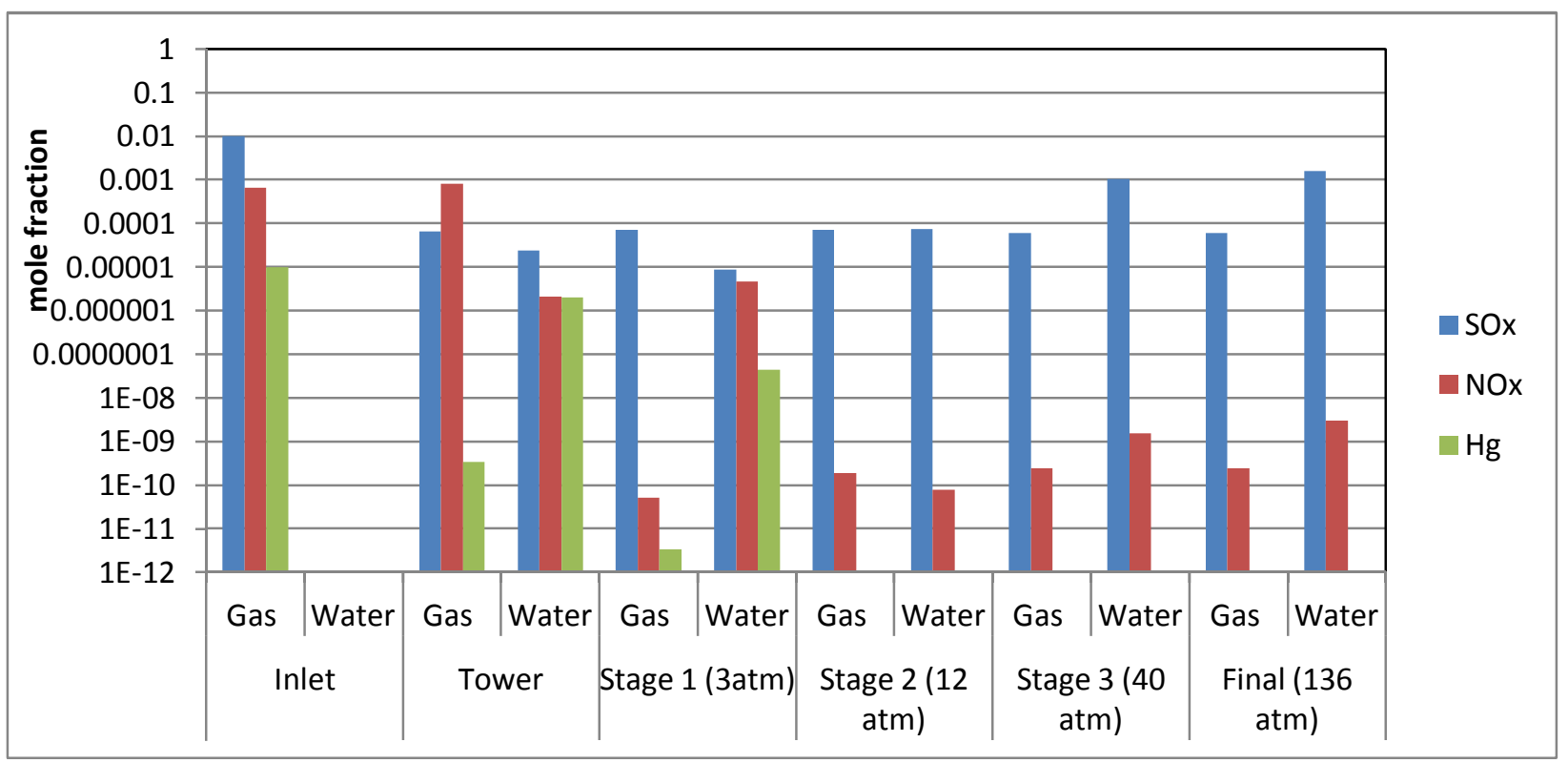

Figure 18 (log scale) - SOx, NOx and Hg as they report to gas and water at the outlets of consecutive process steps in IPR Note that the changes in solute concentration are for decreasing flow-rates of water from IPR.

Compared to field results, model results show the species such as $\mathrm{SO}_{\mathrm{x}}$ and $\mathrm{NO}_{\mathrm{x}}$ are more fully removed in the models. Some of these disagreements between experimental findings and the model predictions are attributed to equilibrium being used to predict a non-equilibrium process-perhaps because interactions within the IPR process may be kinetically controlled. The time which a given amount of material remains at a given pressure and temperature is limited in IPR, so the process gas may be moved to a new IPR stage before it has time to reach equilibrium composition. Differences are also expected in the behavior of the physical spray tower as compared to the tower built in ASPEN which assumes a better liquid distribution than is seen in the physical tower. Also, the IPR simulation was done in a steady-state mode whereas the process measured in the field generally was not at steady state. Dynamic modeling will be required to verify the source of the differences between the existing experiments and the steady-state models.

From the viewpoint of heat transfer, pinch principles were deployed for targeting, design, and operation-guiding purposes, balancing the heat, and mass transfer in the IPR system ${ }^{7}$.

- Most of the sensible and some of the latent thermal energy from flue gas is captured at the spray tower.

- Some of the remaining useful energy is also recovered in heat exchangers minimizing the amount of heat dumped to cooling towers serving the plan.

- From the simulated results and enthalpy calculations: the total power entering into the system is around $394000 \mathrm{~kJ} / \mathrm{hr}$ 
(374000 btu/hr); $\quad 21,700 \mathrm{~kJ} / \mathrm{hr} \quad(20,500 \mathrm{Btu} / \mathrm{hr})$ (approximately $5.5 \%$ of the total) can be recovered at heat exchanger 1 , which is the greatest recovery rate in IPR (this, however, occurs at $40^{\circ} \mathrm{C}$ and so is available to warming processes, such as drying). The temperature here is selectable by adjusting the flow-rate of spray. A lower flow rate will result in a higher temperature condensate in the tower. Tower temperature will also be affected by tower pressure and the optimization of pressurization with heattransfer temperature may improve plant efficiency.

- Around $18,000 \mathrm{~kJ} / \mathrm{hr}$, heat can be extracted from other remaining heat exchangers.

Scaling the slipstream installation model to treat $4,540 \mathrm{~kg} / \mathrm{hr}$ $(10,000 \mathrm{lb} / \mathrm{hr})$ flue gas, approximately $1.10 \mathrm{MW}$ (3.76 MMBtu/hr) of heat can be recovered. Modeling the behavior of IPR systems for power plants shows that energy recovery and pollution removal can be achieved from fluegas streams.

iii. Captured water analysis and results

The average concentration values for dissolved material are shown in Figure 19. Sulfur was the most abundant element found in the flue-gas water (Figure 19). Water samples collected at $\mathrm{H} 1$ (under the spray tower) had the highest sulfur content of $511 \mathrm{~g} / \mathrm{L}$. Sulfur analysis of the city water used to prepare the tower buffer solution (and to initially prime the spray-tower portion of IPR) yielded a value of $12.8 \mathrm{mg} / \mathrm{L}$, a negligible value when compared to the amount of sulfur present in the wastewater samples. Sulfur originates in the coal and forms sulfur dioxide and sulfur trioxide during combustion. In the tower, an initial charge of sodium carbonate $\left(\mathrm{Na}_{2} \mathrm{CO}_{3}\right)$ reacts directly with the $\mathrm{SO}_{2}$ to form sodium sulfite and $\mathrm{CO}_{2}$. The sulfite then reacts with more $\mathrm{SO}_{2}$ and water to form sodium bisulfate. Some of the sodium sulfite is oxidized by excess oxygen in the flue gas to form sodium sulfate $\left(\mathrm{Na}_{2} \mathrm{SO}_{4}\right)$. The following are the reactions occurring during absorption process.

$$
\begin{gathered}
\mathrm{SO}_{2}(\mathrm{~g}) \leftrightarrow \mathrm{SO}_{2}(\mathrm{aq}) \text { (Dissolving gaseous } \mathrm{SO}_{2} \text { ) } \\
\mathrm{SO}_{2}(\mathrm{aq})+\mathrm{H}_{2} \mathrm{O} \leftrightarrow \mathrm{HSO}_{3}^{-}+\mathrm{H}^{+} \text {(Hydrolysis of } \mathrm{SO}_{2} \text { ) } \\
\mathrm{HCO}_{3}^{-}+\mathrm{H}^{+} \leftrightarrow \mathrm{CO}_{2}(\mathrm{aq})+\mathrm{H}_{2} \mathrm{O} \\
\mathrm{O}_{2}(\mathrm{~g})+2 \mathrm{HSO}_{3}^{-} \rightarrow 2 \mathrm{SO}_{4}^{-}+2 \mathrm{H}^{+} \text {(Sulfur oxidation) }
\end{gathered}
$$




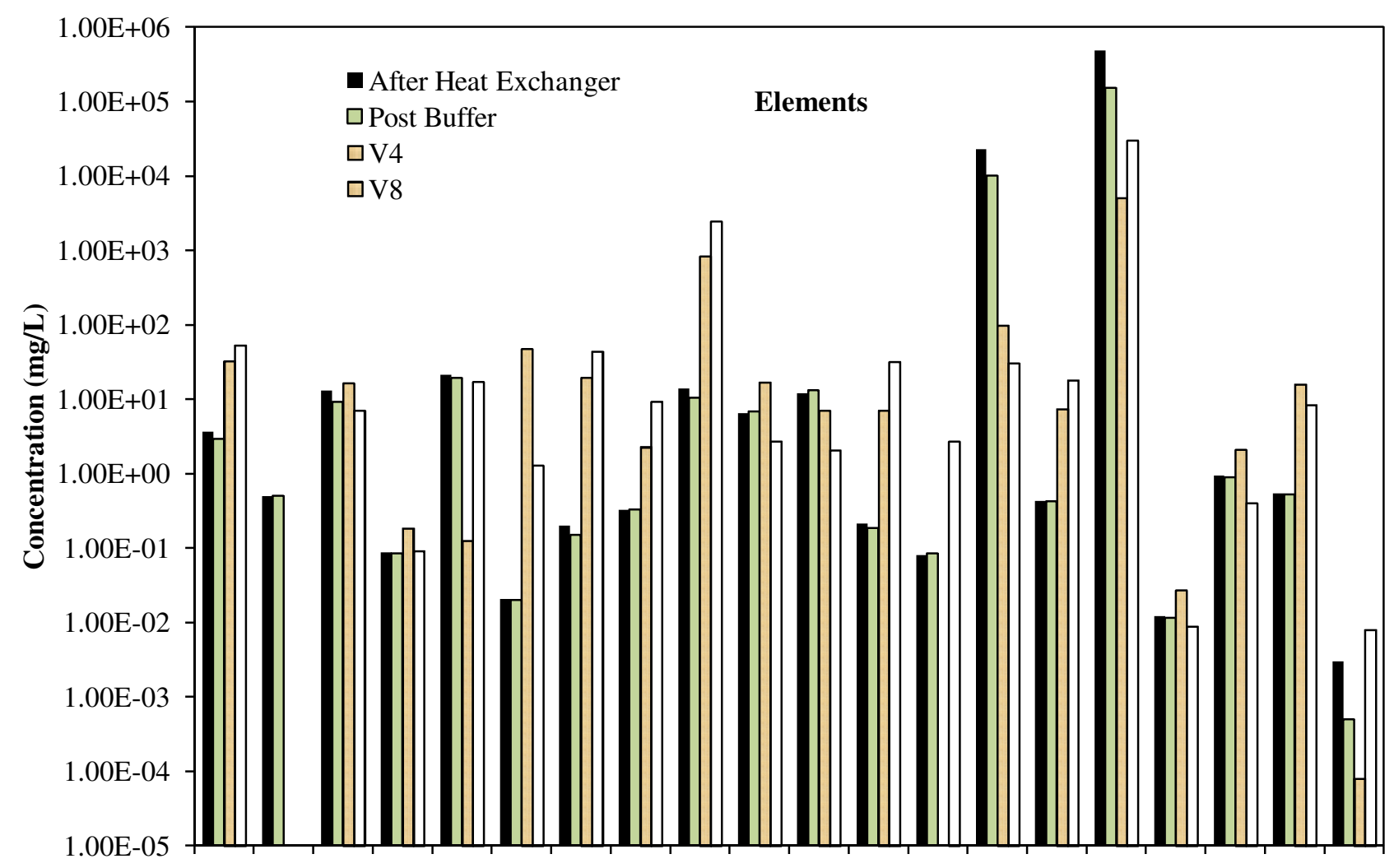

Figure 19: Average concentration of elements in wastewater

Sodium was the second most common element found in the wastewater samples collected after the heat exchanger $(\mathrm{H} 1)$ and post buffer points (Figure 19) and the concentrations were $35 \mathrm{~g} / \mathrm{L}$ and $10 \mathrm{~g} / \mathrm{L}$ respectively. The most likely source of the sodium is the $\mathrm{Na}_{2} \mathrm{CO}_{3}$-buffer solution added to tower spraywater for sulfur removal. The sodium content in city water was tested as a baseline and was found to be $9.51 \mathrm{mg} / \mathrm{L}$. The buffer solution prepared from this water was $1 \mathrm{M}$ concentration.

There was an increase in chromium concentration in water from the higher-pressure stages of IPR as compared to the lowerpressure stages. Considering that the $\mathrm{pH}$ levels in the highpressure areas are acidic, it is suspected that one source of the chromium is corrosion of stainless steel piping and equipment. This is not unexpected, as 316 stainless is known to interact with sulfuric acid. Iron and copper concentration profiles closely followed chromium concentration profiles. At $\mathrm{pH}$ values below about 5, both iron and copper corrode rapidly and uniformly. The $\mathrm{pH}$ of liquid samples collected from V4 and V8 samples was generally 1 . Thus, it is suspected that one source of the iron and copper is corrosion of metallic equipment. Again, this is not unexpected. Electrochemical corrosion measurements will 
be used to track the locations and operational settings with respect to corrosion rates to provide data which will be used to optimize material choices for different parts of larger-scale iterations of the IPR system. Concentrations of $\mathrm{Mn}$ in water collected at $\mathrm{H} 1$ and $\mathrm{B} 1$ were $0.2 \mathrm{mg} / \mathrm{L}$. Manganese also had higher concentrations in V4 and V8 as compared to the $\mathrm{H} 1$ and B1 samples

Divalent cations such as calcium and magnesium were also present significantly in IPR- water. The concentrations of calcium and magnesium were $28.75 \mathrm{mg} / \mathrm{L}$ and $12.85 \mathrm{mg} / \mathrm{L}$ respectively. The total water hardness, including both $\mathrm{Ca}^{2+}$ and $\mathrm{Mg}^{2+}$ ions, is reported in parts per million (ppm) of calcium carbonate $\left(\mathrm{CaCO}_{3}\right)$ in the water is approximately $152 \mathrm{ppm}$. Although water hardness usually measures only the total concentrations of calcium and magnesium (the two most prevalent divalent metal ions), iron, aluminum, and manganese may be added to the hardness calculation if they are high in concentration. General guidelines for hardness classification are: 0 to $60 \mathrm{mg} / \mathrm{L}$ as calcium carbonate is classified as soft; 61 to $120 \mathrm{mg} / \mathrm{L}$ as moderately hard; 121 to $180 \mathrm{mg} / \mathrm{L}$ as hard; and more than $180 \mathrm{mg} / \mathrm{L}$ as very hard ${ }^{15}$. Flue-gas water from the IPR system is considered moderately hard.

$\mathrm{pH}$

The average $\mathrm{pH}$ of water samples from $\mathrm{H} 1$ (see Figure 21) collected was 6.36 where as it was 6.71 in B1 measurements. Our aim was to maintain the solution $\mathrm{pH}$ between 5 to 7 using sodium carbonate buffer solution in order to strip more $\mathrm{SO}_{2}$ from flue gas and for other possible reactions. From previous results, the average $\mathrm{pH}$ of $\mathrm{V} 4$ and $\mathrm{V} 8$ samples were 1.0 and 0.2 respectively. It is suspected this was due to the formation of $\mathrm{H}_{2} \mathrm{SO}_{4}$ at high pressure and high temperature. After treating $\mathrm{H} 1$ derived wastewater with coagulant, the $\mathrm{pH}$ increased from 6.36 to 9.4. This final $\mathrm{pH}$ of the water exiting the full treatment process will be neutral, which is considered the general treatment target ZLD systems.

Alkalinity

Alkalinity is a measure of the ability of water to neutralize acids and bases and predicts the formation of carbonate precipitates. Alkalinities are compared in Figure 20. High alkalinity values were recorded due to sodium carbonate buffer solution. The average alkalinity of post buffer (B1) and after heat exchanger $(\mathrm{H} 1)$ were $20000 \mathrm{mg} / \mathrm{L}$ and $12000 \mathrm{mg} / \mathrm{L} \mathrm{CaCO}_{3}$ respectively After treating the wastewater collected from heat exchanger, the alkalinity increased to $16600 \mathrm{mg} / \mathrm{L} \mathrm{CaCO}_{3}$. Water with high alkalinity may cause scale buildup in plumbing. The removal of alkalinity ions can be achieved either through ion exchange 
resins or reverse osmosis units. The preferred process at this point is reverse osmosis.

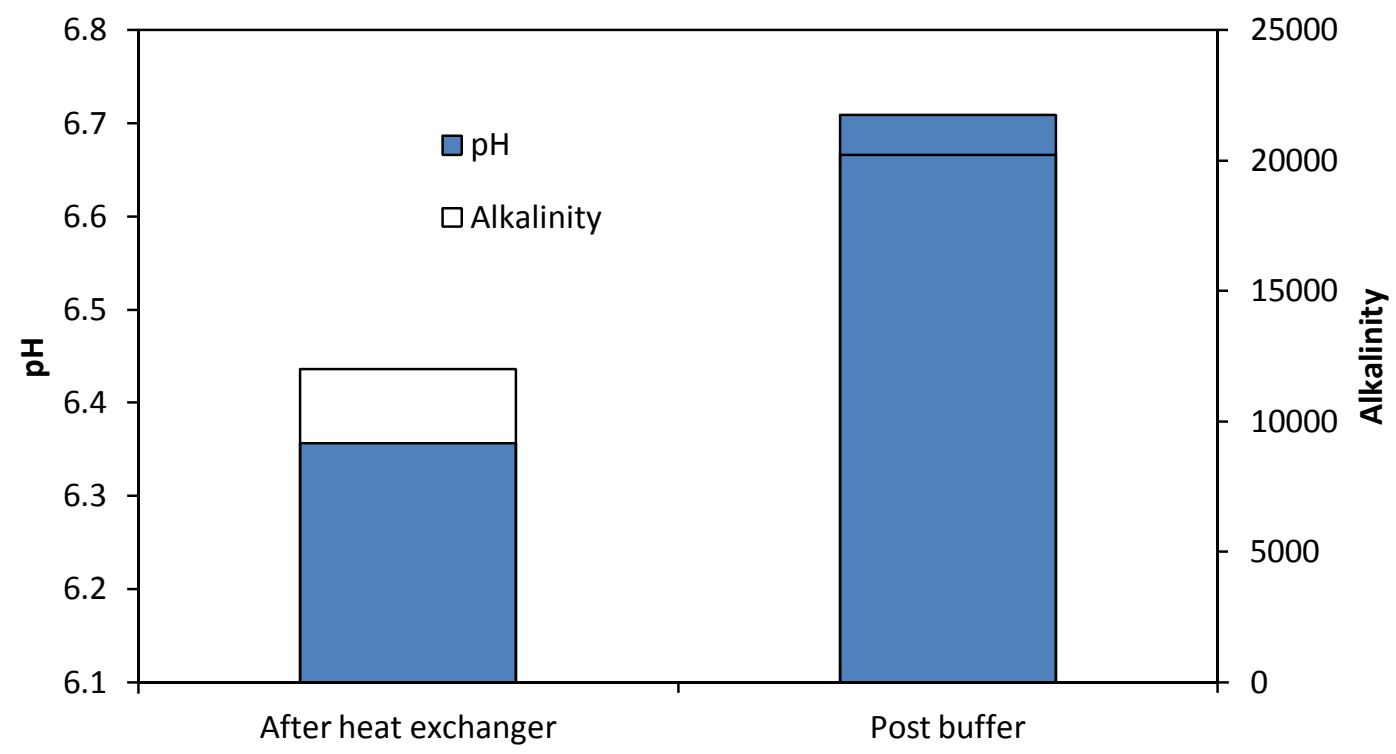

Figure 20: $\mathrm{pH}$, Alkalinity variation of wastewater collected

Ferric chloride achieved turbidity removal of more than $99 \%$ (Figure 21). Turbidity removal values for different wastewater samples are shown in Figure 22 where flue-gas water was dosed with $2 \mathrm{~g}$ of $\mathrm{FeCl}_{3}$ per liter. Elemental removal efficiencies from this dosage are shown in Figure 23. More than $50 \%$ of heavy metals such as $\mathrm{Al}, \mathrm{Ba}, \mathrm{Ca}, \mathrm{Cr}, \mathrm{Fe}, \mathrm{Si}, \mathrm{Ti}, \mathrm{Zn}$ present in wastewater samples were removed by ferric chloride. Hardnesscausing ions such as $45 \%$ of magnesium and $58 \%$ of calcium were removed. After the coagulation and flocculation experiments, flue gas condensed water is considered moderately hard since the total concentrations of hardness causing ions are less than $80 \mathrm{ppm} \mathrm{CaCO}_{3}{ }^{15}$. $85 \%$ of $\mathrm{Hg}$ was removed from wastewater. Except those elements mentioned above, other elements occurred in concentrations less than $1 \mathrm{mg} / \mathrm{L}$. 


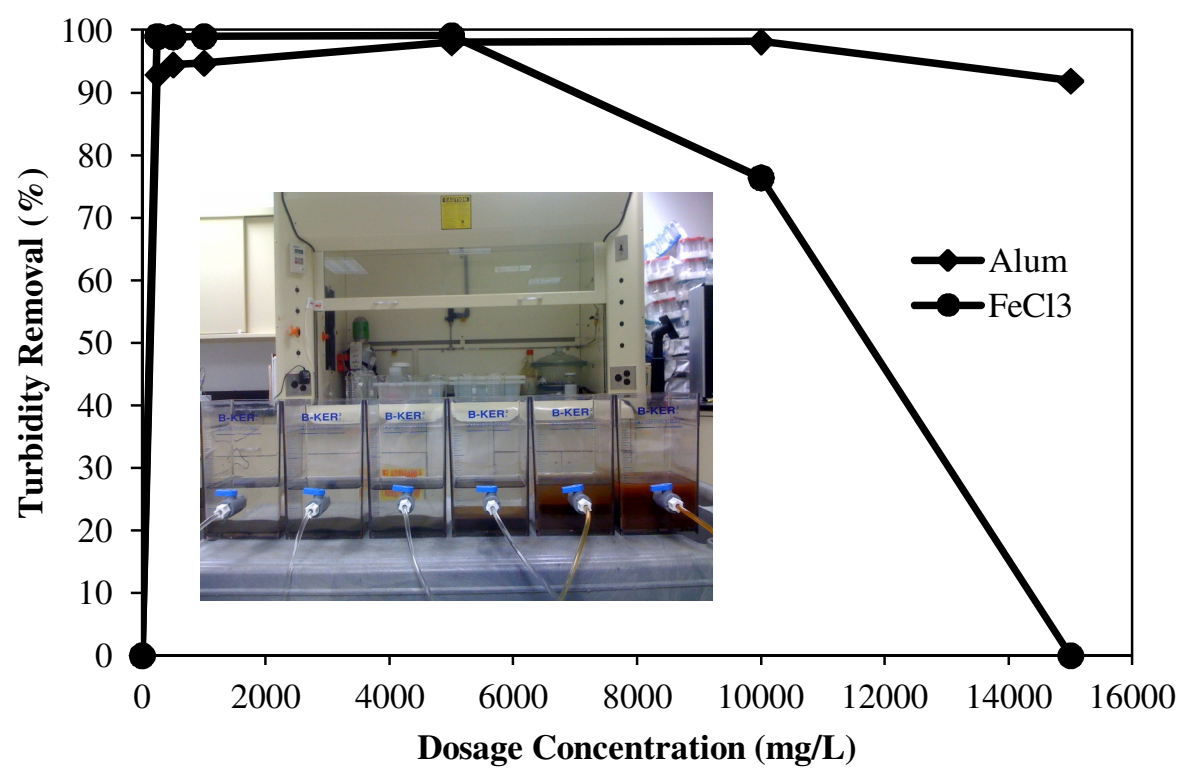

Figure 21: Comparison of turbidity removal using $\mathrm{FeCl}_{3}$ and Alum on wastewater samples

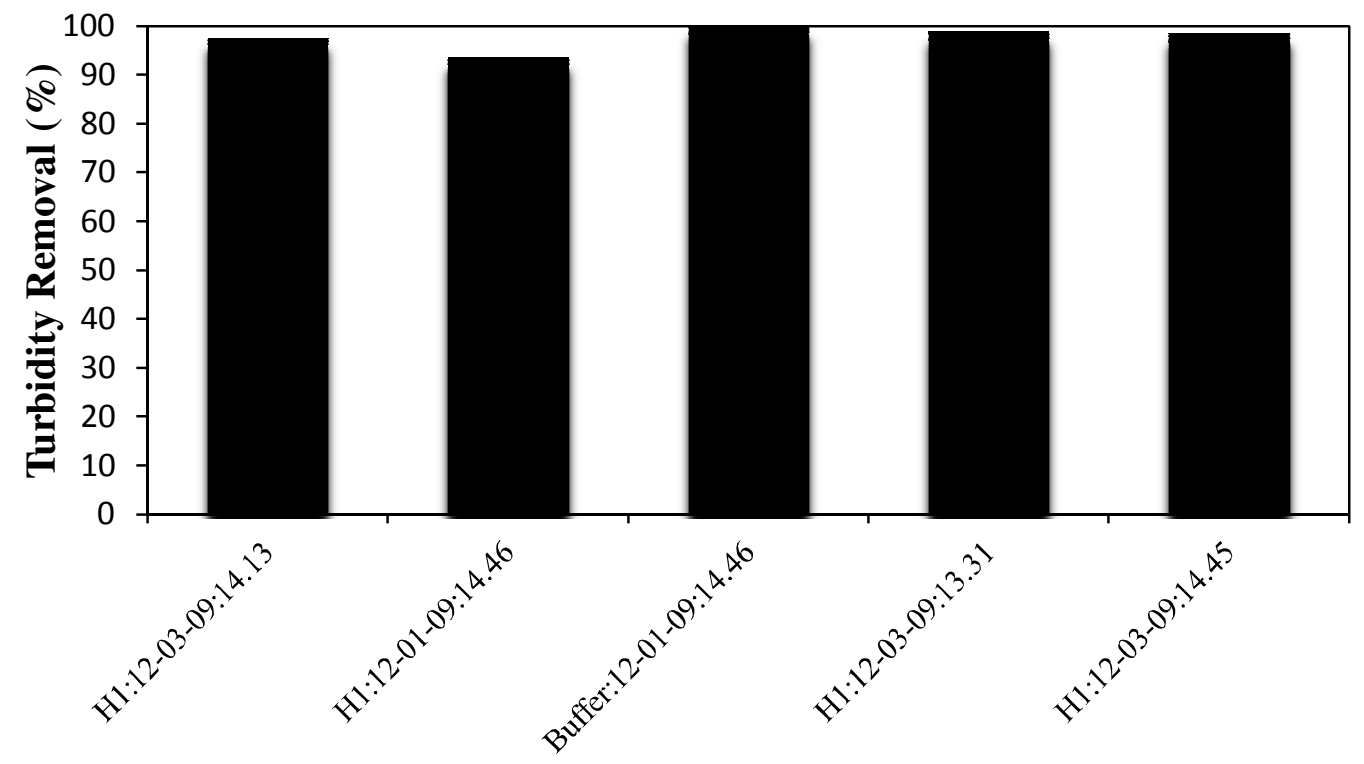

Figure 22: Comparison of turbidity removal using $\mathrm{FeCl}_{3}$ and Alum on wastewater samples 


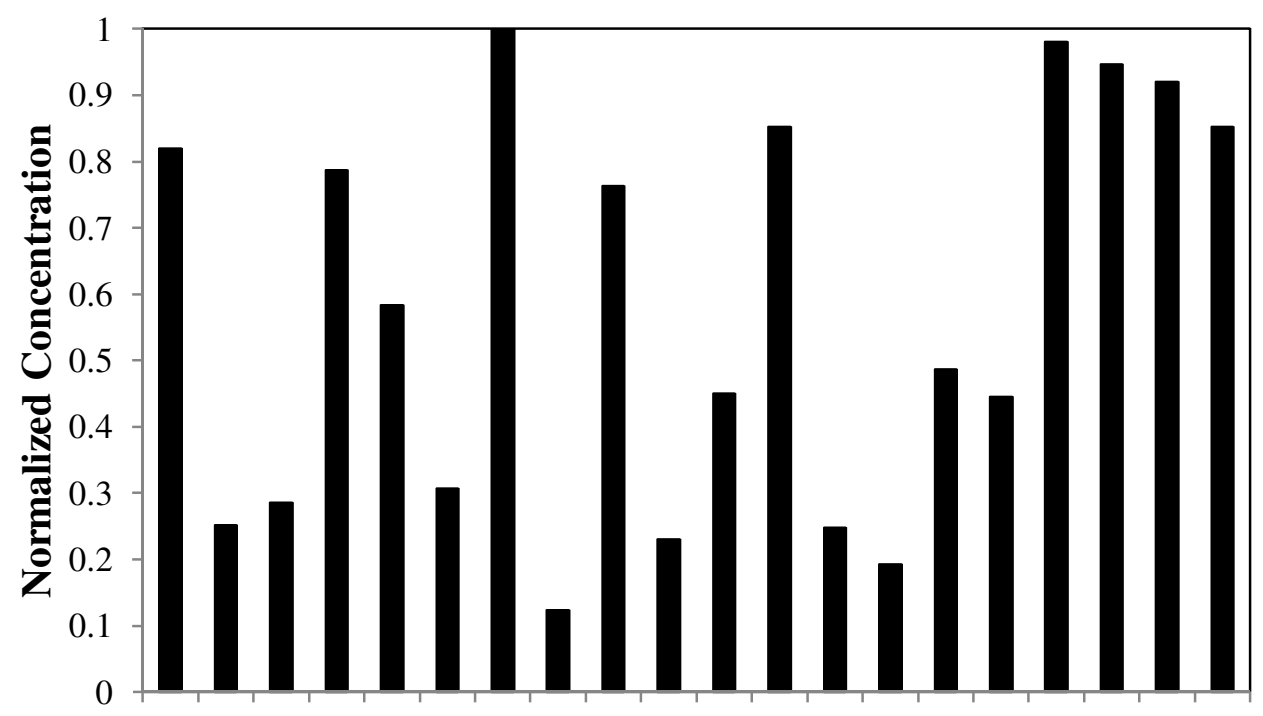

Al As B Ba Ca Co Cr Cu Fe K Mg Mn Mo Na Ni S Si Ti Zn Hg

Elements

Figure 23: Normalized cations removal from flue gas condensed wastewater

As shown in Figure 24, sulfate $\left(\mathrm{SO}_{4}^{-}\right)$, bicarbonate $\left(\mathrm{HCO}_{3}{ }^{-}\right)$, chloride $\left(\mathrm{Cl}^{-}\right)$and nitrate $\left(\mathrm{NO}_{3}{ }^{-}\right)$anions were found substantially in flue gas wastewater. Fluoride $\left(\mathrm{F}^{-}\right)$, nitrite $\left(\mathrm{NO}_{2}{ }^{-}\right)$and bromide $\left(\mathrm{Br}^{-}\right)$were present in very small quantities. After sulfate, the second most abundant anion found was bicarbonate ion which was due to the sodium bicarbonate buffer solution used in absorption column during IPR run. We surmise that chloride ions are mainly from $\mathrm{FeCl}_{3}$ coagulant dosage. It seems $\mathrm{NO}$ and $\mathrm{NO}_{2}$ oxides present in flue gas are forming nitrates in wastewater. The following are the possible reactions occurring during scrubbing operation in absorption column.

$\mathrm{NO}+\mathrm{NO}_{2}+\mathrm{H}_{2} \mathrm{O} \leftrightarrow 2.0 \mathrm{HNO}_{2}$ (formation of nitrous acid) $\mathrm{HNO}_{2}+\mathrm{H}_{2} \mathrm{O} \leftrightarrow \mathrm{H}_{3} \mathrm{O}^{+}+\mathrm{NO}_{2}^{-}$(solubilzation) $2.0 \mathrm{NO}_{2}+0.5 \mathrm{O}_{2}+\mathrm{H}_{2} \mathrm{O} \leftrightarrow 2.0 \mathrm{HNO}_{3}$ (formation of nitric acid) $\mathrm{HNO}_{3}+\mathrm{H}_{2} \mathrm{O} \leftrightarrow \mathrm{H}_{3} \mathrm{O}^{+}+\mathrm{NO}_{3}{ }^{-}$(solubilzation)

Very little of the anionic species present in waste water samples were removed using either $\mathrm{FeCl}_{3}$ alum. 




Figure 24: Concentrations of anions present in water sample before and after water treatment

A polymer (Chemway 540) was used as coagulant aid for turbidity removal. Wastewater sample was coagulated using $2 \mathrm{~g}$ $\mathrm{FeCl}_{3}$ with and without the addition of $0.5 \mathrm{~g}$ polymer per liter of flue-gas water. The results are shown in Figure 25. With the addition of $0.5 \mathrm{~g}$ polymer and $2 \mathrm{~g} \mathrm{FeCl}_{3}$ the turbidity removal of $93 \%$ achieved within 5 minutes whereas without the polymer the turbidity removal was only $74 \%$. Higher turbidity removal within a shorter time period points to the practicability of build an in-line treatment of water for re-use in the IPR systems. 


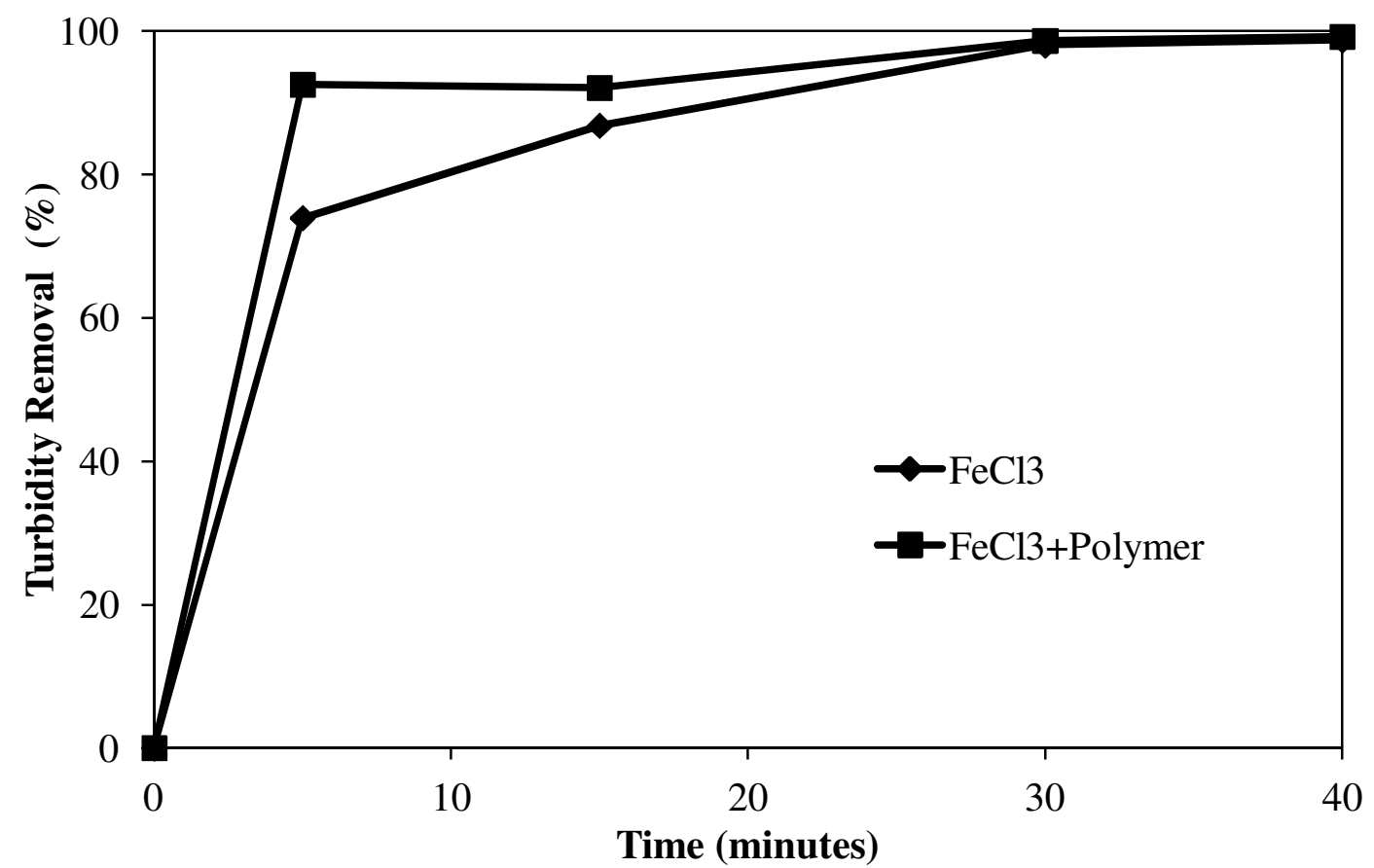

Figure 25: Comparison of turbidity removal using $\mathrm{FeCl}_{3}$ and $\mathrm{FeCl}_{3}+\mathrm{Polymer}$

Elemental analysis of digested sludge from IPR-water shows Al, $\mathrm{Ca}, \mathrm{Fe}, \mathrm{K}, \mathrm{Mg}, \mathrm{Na}, \mathrm{S}, \mathrm{Si}$ are the major components of the sludge. As, B, Ba, Co, Cr, Cu, Mn, Mo, $\mathrm{Ni}$ are found in small quantities. The amount of $\mathrm{Hg}$ present in the sludge is around $1.508 \mathrm{E}-03 \mathrm{mg} / \mathrm{g}$. The amount and characteristics of the sludge produced during the coagulation/flocculation process are highly dependent on the specific coagulant used and on the operating conditions. In this study, the sludge volume was estimated by measuring the height of the sludge layer at the bottom of the jartest beakers. The sludge mainly contains fly ash particles (elemental analysis in Figure 26). The color change is due to the coagulant, ferric chloride. According to the American Society for Testing Materials (ASTM C618), ashes containing more than 70 wt $\% \mathrm{SiO}_{2}+\mathrm{Al}_{2} \mathrm{O}_{3}+\mathrm{Fe}_{2} \mathrm{O}_{3}$ and low in lime are defined as Class $\mathrm{F}$ while those with a $\mathrm{SiO}_{2}+\mathrm{Al}_{2} \mathrm{O}_{3}+\mathrm{Fe}_{2} \mathrm{O}_{3}$ content between 50 and 70 wt \% and high in lime are defined as Class C. Briefly, the high calcium Class $C$ fly ashes are normally produced from the burning of low rank coals (lignites or sub bituminous coals) and have cementitious properties (self hardening when reacted with water). On the other hand the low calcium Class $F$ flyashes are commonly produced from the burning of higher rank coals (Table 8) (bituminous coals or anthracites) that are pozzolanic in nature (hardening when reacted with $\mathrm{Ca}(\mathrm{OH})_{2}$ and water. The 
sludge formed contains Class $\mathrm{F}$ flyash particles with calcium around $4 \%$ (Table 9$)^{18}$.



Figure 26: Elemental analysis of sludge removed from wastewater

\begin{tabular}{|c|c|c|}
\hline Components & As received (\%) & Dry (\%) \\
\hline Moisture & 4.12 & 0 \\
\hline Ash & 12.47 & 13.01 \\
\hline Volatile matter & 34.62 & 36.11 \\
\hline Fixed carbon & 48.79 & 50.88 \\
\hline Sulfur & 3.48 & 3.63 \\
\hline Gross calorific & 12074 & 12593 \\
\hline Carbon & 66.67 & 69.53 \\
\hline Hydrogen & 4.53 & 4.73 \\
\hline Nitrogen & 1.37 & 1.43 \\
\hline Oxygen & 7.36 & 7.67 \\
\hline
\end{tabular}

Table 8: Typical composition of coal analysis 


\begin{tabular}{|c|c|}
\hline Elements as oxides & Wt \% \\
\hline $\mathrm{SiO}_{2}$ & 50.93 \\
\hline $\mathrm{Al}_{2} \mathrm{O}_{3}$ & 19.44 \\
\hline $\mathrm{Fe}_{2} \mathrm{O}_{3}$ & 18.11 \\
\hline $\mathrm{CaO}$ & 4.74 \\
\hline $\mathrm{K}_{2} \mathrm{O}$ & 2.26 \\
\hline $\mathrm{SO}_{3}$ & 1.88 \\
\hline Other oxides & 2.64 \\
\hline
\end{tabular}

Table 9: Typical oxides in fly ash

Specifications for the water-treatment process (flocculation / coagulation, followed by reverse osmosis and evaporation / crystallization) delineated for IPR flue-gas water are being expanded upon through continued experimentation. Recovery, treatment and in-plant use of flue-gas water will decrease a power-plant's demand for water from the environment. Specifically (since the settling rate with $\mathrm{FeCl}_{3}$ is very fast), spray-water for direct-contact heat exchangers (DCHX) may be prepared from raw flue-gas water by using only the flocculation/coagulation process.

Out of all elements sulfur and sodium were the most prevalent in the wastewater. This is due to high sulfur content present in coal and to the sodium carbonate buffering solution.

Ferric chloride coagulant removed more than $99 \%$ of turbidity and a significant amount of cations. It was less effective at removal of the anions.

iv. Corrosion studies

In situ tests at Hammond Pest Facility used multiple-technique electrochemical corrosion-monitoring technology to collect information on corrosion rates and susceptibility to pitting of the metallic materials of interest. The corrosion-monitoring technology used electrochemical noise, linear polarization resistance, and harmonic distortion analyses to acquire corrosion rates and derive pitting factors (PF), which are calculated from the electrochemical noise and the electrochemical harmonic data. 316 stainless steel (the material used to build the Hammond Pest Facility IPR) and Inconel 625 were the materials of interest. These metallic materials were used as electrodes in three electrode corrosion sensors configured as probe sensors (see Figure 27) or flange sensors 
(see Figure 28). Corrosion sensors also act as test coupons. In situ sensors were installed in line at various locations in the IPR environment system (see Figure 28) for measurements of the rates of corrosion and localized pitting. Figures 27, 28, and 29 and Table 10, all below, illustrate the probes, locations, and test conditions.

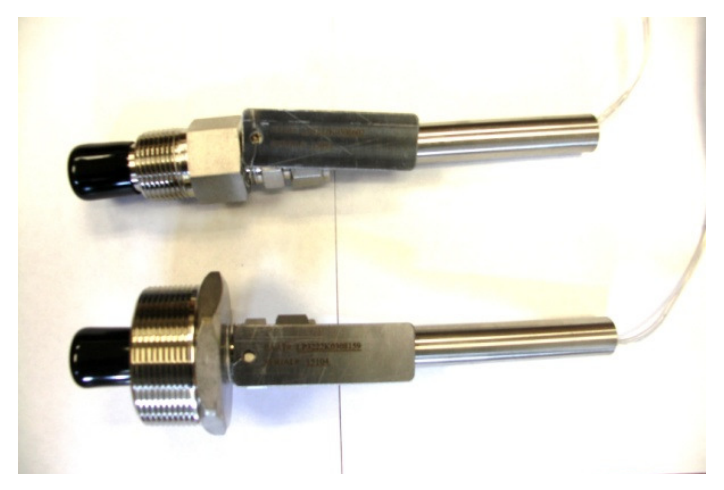

Figure 27: Three Electrode Immersion Probe



Figure 28: Three Electrode Flange Probe 




Figure 29: IPR System Schematic with Probe Locations

\begin{tabular}{|l|l|l|l|l|l|l|}
\hline & Position & Section & $\begin{array}{l}\text { Temp. } \\
\text { o C }\end{array}$ & Pressure, psia & $\begin{array}{l}\text { Direction to } \\
\text { Flow }\end{array}$ & Probe \\
\hline 1 & Right FGR Tap & 2" Cross & $\begin{array}{l}150- \\
170\end{array}$ & 15.4 (Stream 2) & vertical & Flat Immersion \\
\hline 2 & Left HX & $\begin{array}{l}\text { 2" Tee } \\
\text { (existing) }\end{array}$ & $50-60$ & $<15.4$ & vertical & Flat Immersion \\
\hline 3 & Left H2 & 1" Tube & $\begin{array}{l}150- \\
170\end{array}$ & $50-60$ & horizontal & Flange \\
\hline 4 & Right H2 & 1" Cross & $\begin{array}{l}15-20 \\
1 \text { (" Cross }\end{array}$ & $50-60$ & vertical & Flat Immersion \\
\hline 5 & V4 & 1" Tube & $\begin{array}{l}150- \\
170\end{array}$ & 190 & vertical & Flat Immersion \\
\hline 6 & Left H3 & 1" Tee & $15-20$ & 190 & horizontal & Flange \\
\hline 7 & V8 & 150 & vertical & Flat Immersion \\
\hline
\end{tabular}

Table 10: Description of Probes and Test Conditions

In the laboratory, experiments that involve potentiodynamic techniques, electrochemical impedance spectroscopy, and immersion tests are being performed on select metallic materials in simulated IPR aqueous solutions at low pressure and low temperature. Corrosion rates and susceptibility to pitting are determined by using linear polarization, cyclic voltammetery, and electrochemical impedance spectroscopy, as well as by immersion tests in simulated IPR aqueous solutions at low 
pressure and low temperature using a typical three-electrode electrochemical cell. These electrochemical experiments allow for accurate prediction of materials performance in corrosive environments and thus allow for rapid screening and identification of materials for application. Results of in situ and laboratorybased tests will be presented in future publications. Results to date for in-situ tests are given below.

The figure below shows the location of probes in liquidaccumulation vessels, V4 and V8, where liquid and gas are both present. Probes are periodically covered with liquid as the vessels are filled and emptied.

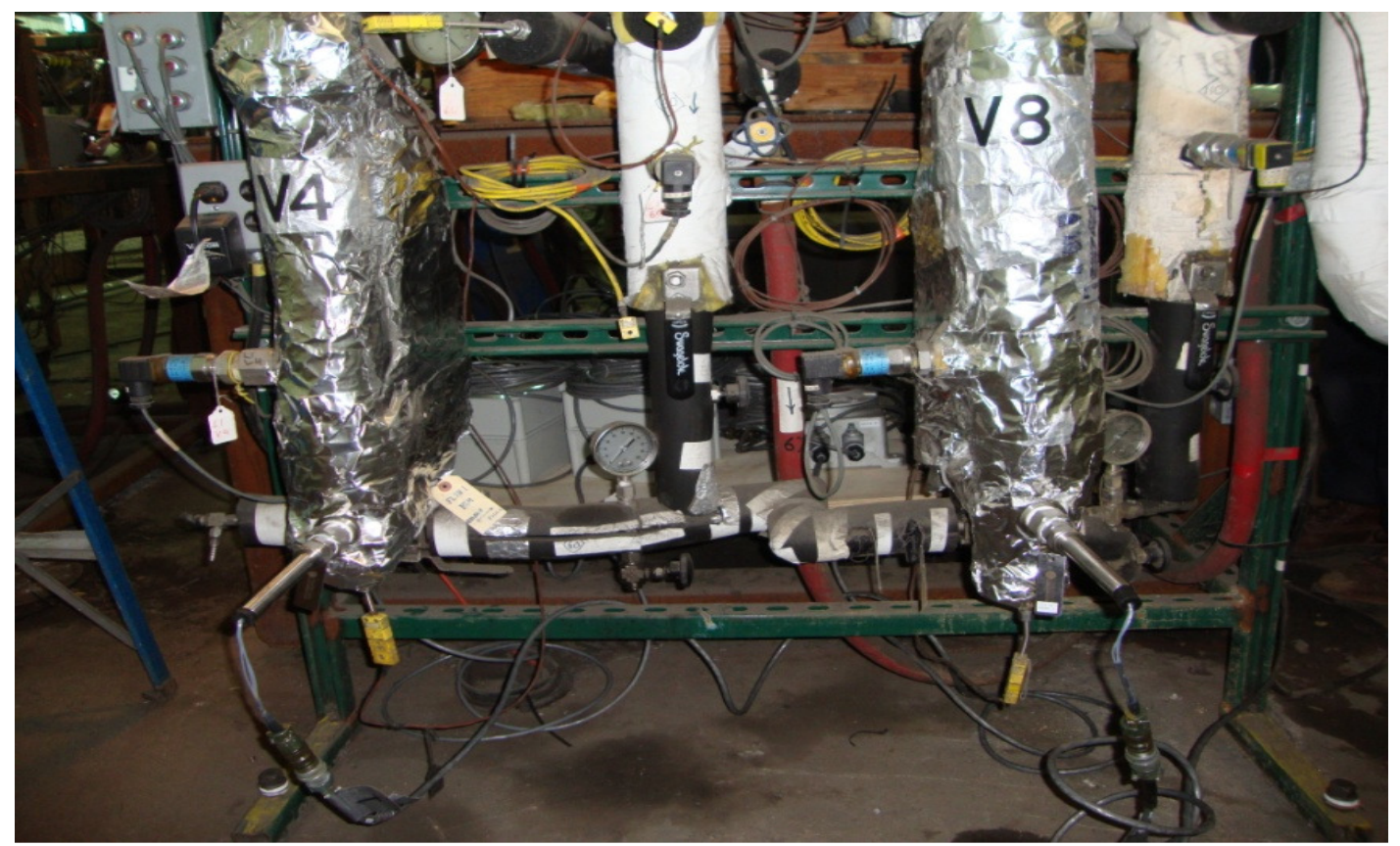

Figure 30: Flat Immersion Probes 5 and 7 


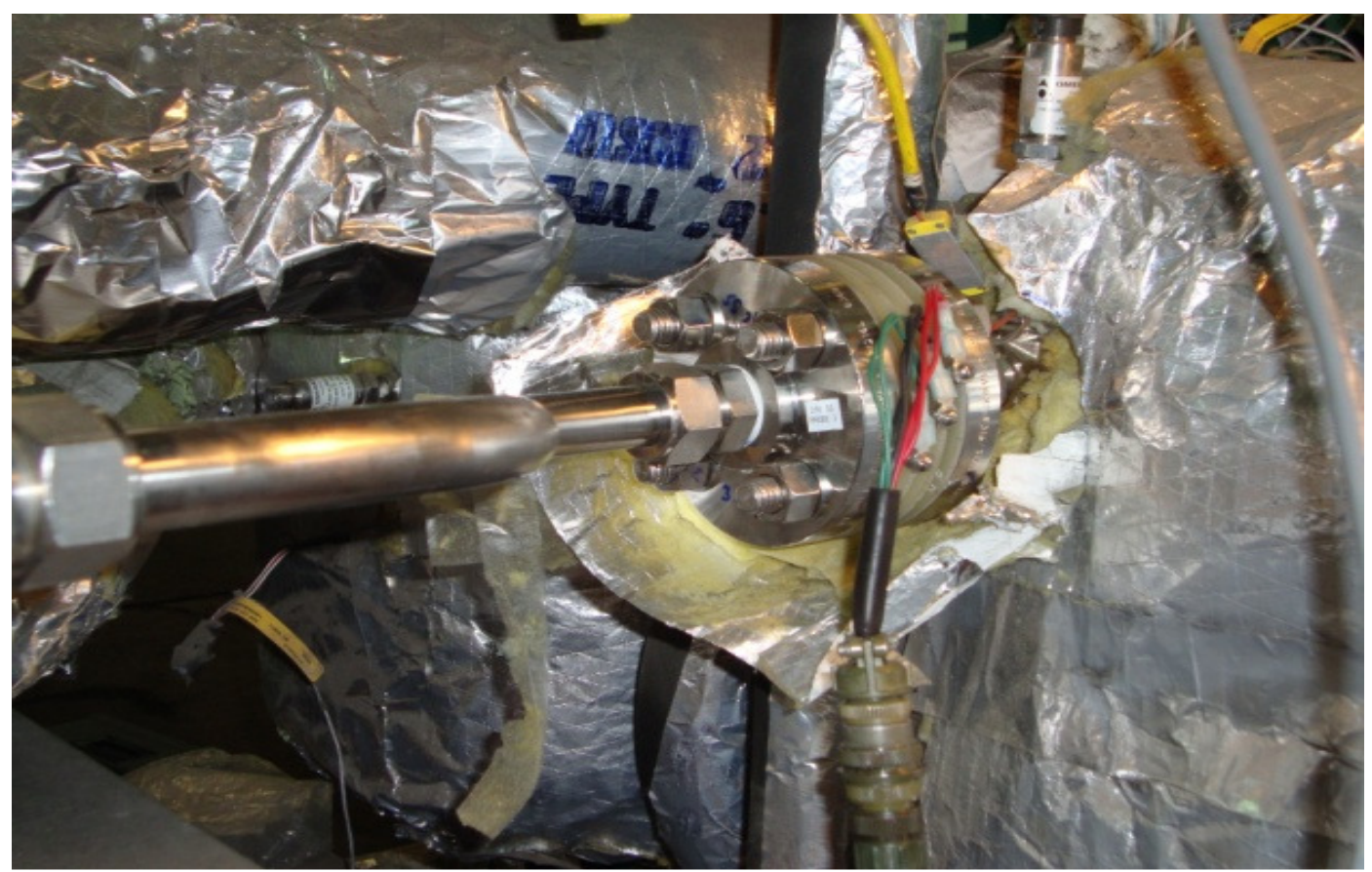

Figure 31: Flange probe - electrodes surround the gas-stream 


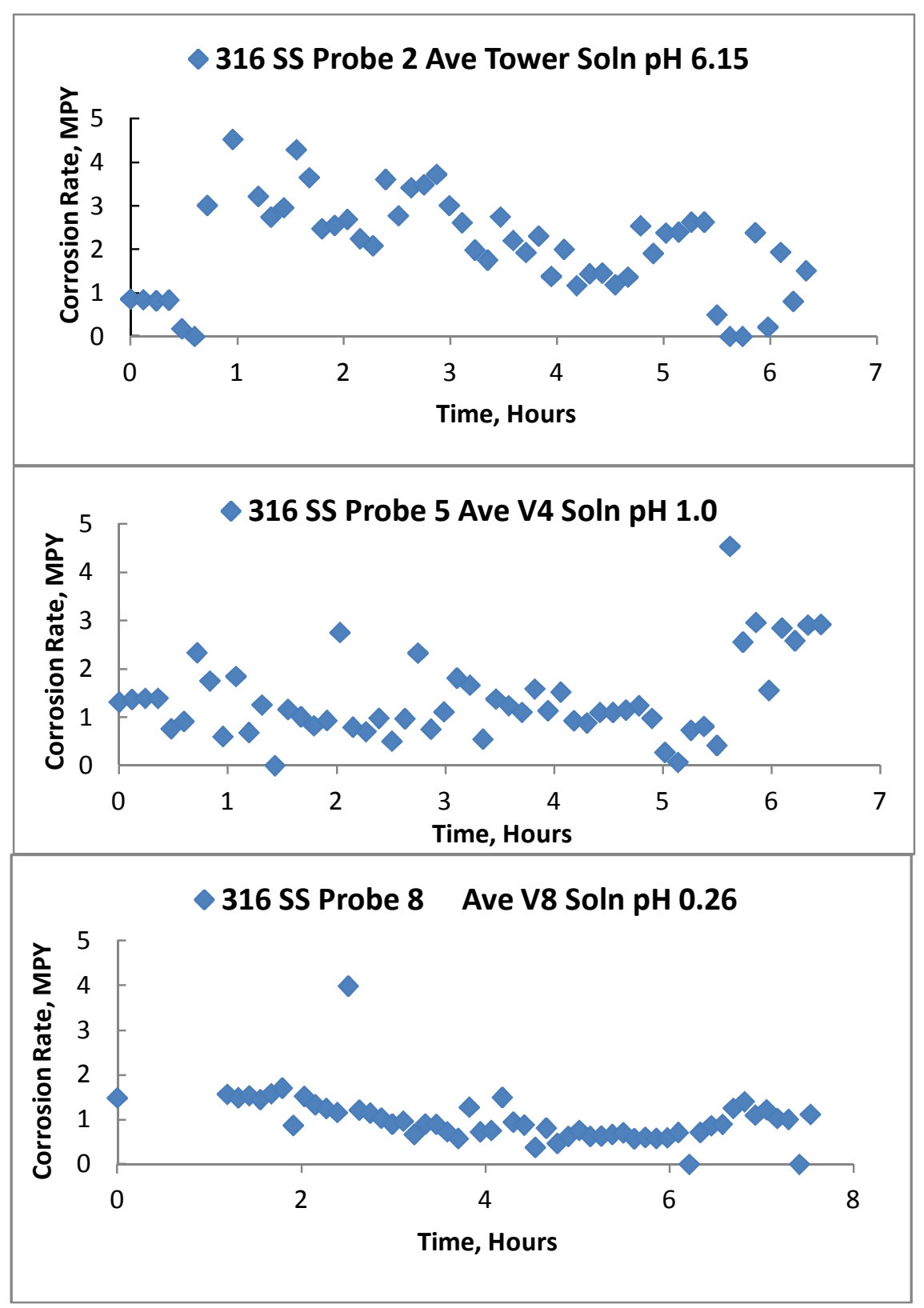

Figure 32: Corrosion rate determined from in-situ 316 SS probes

The results of the 316 SS Probes run in the IPR unit under buffered conditions are $\leq 5$ MPY for Probe 2, $\leq 3$ MPY (milli-inch per year) for Probe 5 , and $\leq 1 \mathrm{MPY}$ for Probe 8 . The corrosion rates decreased as the $\mathrm{pH}$ decreased.

The relative corrosion resistances of $<1 \mathrm{mpy}$ are considered outstanding and from 1-5 mpy are considered excellent. 


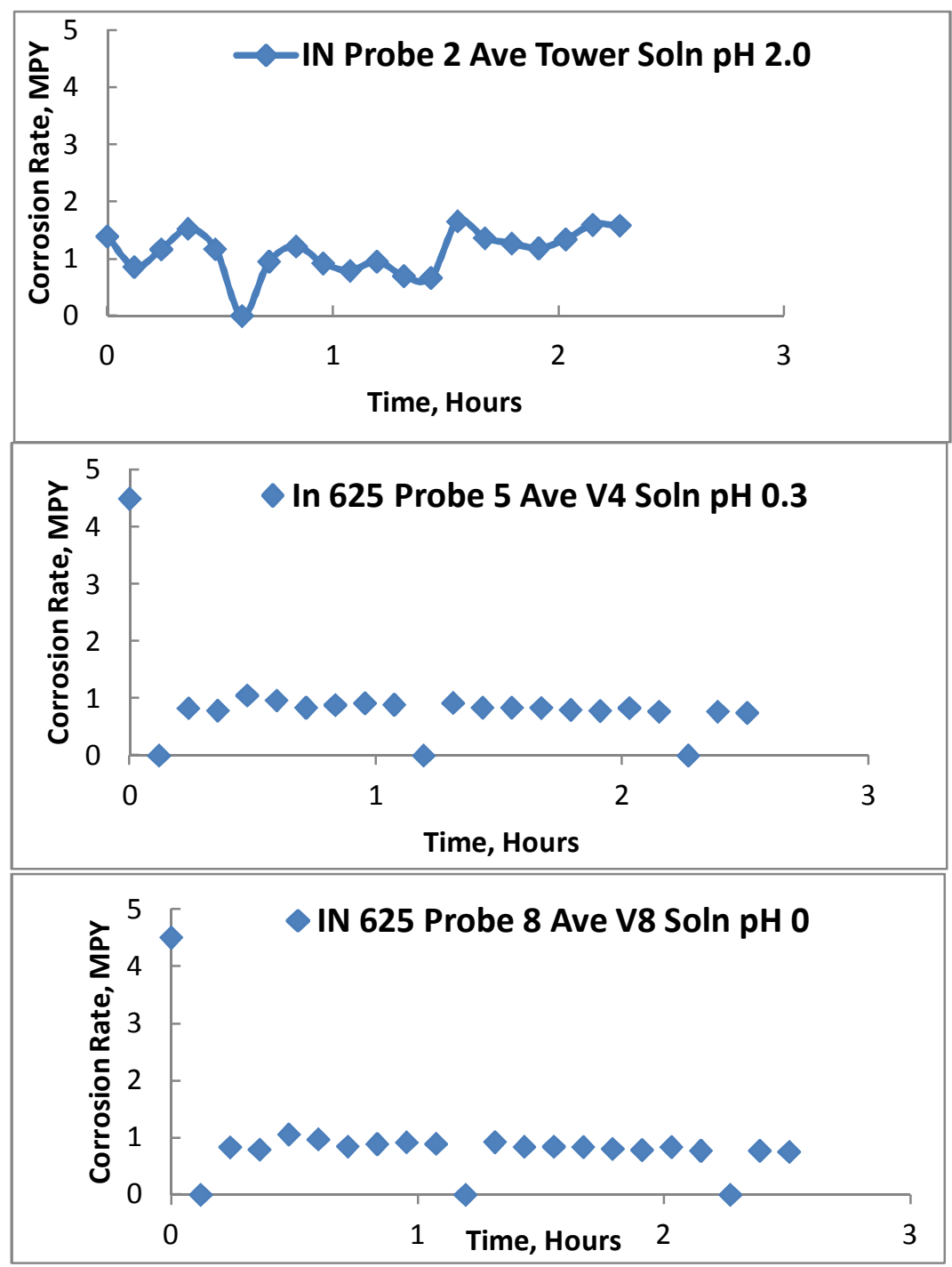

Figure 33: Corrosion rate determined from in-situ inconel probes

The results from the Inconel probes run under un-buffered conditions were $\leq 2 \mathrm{MPY}$ for Probe 2 , and Probe 5 and Probe 8 were $\leq 1.0$. The corrosion rates decreased as the $\mathrm{pH}$ decreased. The relative corrosion resistances of $<1 \mathrm{mpy}$ are considered outstanding and from 1-5 mpy are considered excellent. Note During the tests including the inconel probes, IPR processed fluegas without employing a buffer in the tower. Results shown in the figures show that, even in this harsher environment, inconel performed better than 316SS. 
6. High flame temperature oxy-combustion power plant retrofits

\section{INTRODUCTION}

Jupiter Oxygen is an energy technology company which developed and patented the high flame temperature oxy-combustion for power plants, included retrofit applications. Oxygen is used to combust coal or other fuels in a process which creates a flame temperature higher than air firing, but which can be safely used in retrofitted boilers. The material and water/steam temperatures and flows remain virtually the same as those of air firing to maintain power plant operations with the same gross MW steam turbine performance, with a boiler fuel savings compared to air firing or other carbon capture approaches. Jupiter also has a carbon capture system for high flame oxy-combustion Integrated Pollutant Removal ("IPR ${ }^{\Theta,}$ ) which captures $95-100 \%$ of the $\mathrm{CO}_{2}$, developed with the United States Department of Energy National Energy Technology Laboratory ("NETL"). The reason for the capture range is that the carbon capture system will not have power to operate during power plant start-up and shutdown unless another source of power is available such as from an electricity grid.

This section of the project final report is based on models for a first of a kind [FOAK] large scale coal fired power plant retrofits. The models use data from a $15 \mathrm{MW}$ th test facility with an operating steam boiler and a $\mathrm{CO}_{2}$ capture system of the JOC-NETL project. The NETL team used separate component level models based on a plant that has been extensively modeled in the past by NETL (Connesville Unit 5).

In 2012, utilities are faced with a high level of uncertainty as power plants age and new environmental regulations come on-line. It is not known when there will be a limit set on $\mathrm{CO}_{2}$ and whether it will apply to all coal fired power plants. The section examines three retrofit options:

1. High flame temperature oxy-combustion for a natural gas fired power plant with or without carbon capture

2. High flame temperature oxy-combustion of a coal-fired power plant to use natural gas as the fuel with or without carbon capture

3. High flame temperature oxy-combustion with coal as the fuel and carbon capture

The NETL project team suggested exploring whether coal fired power plants could be converted to natural gas without de-rating using the JOC high flame temperature oxy-combustion approach. Based on this suggestion, Jupiter conducted a separate study with Reaction Engineering International which indicates that this is feasible.

The impact from compliance with regulation of $\mathrm{CO}_{2}$ emissions from coal fired power plants can be mitigated by moving directly to natural gas, although it is 
unclear whether this is an effective long-term solution because of historic natural gas price fluctuations. The NETL project team suggests that utilities should consider a progression of possible modifications for coal fired power plants to meet carbon capture requirements, considering whether option 2 above should proceed option 3. Potential staged approaches include use of natural gas which produces less $\mathrm{CO}_{2}$ as well as sufficient partial $\mathrm{CO}_{2}$ capture to meet EPA requirements.

In considering high flame oxy-combustion with natural gas and with coal as fuels, the differences in improved radiant heat transfer must be considered:

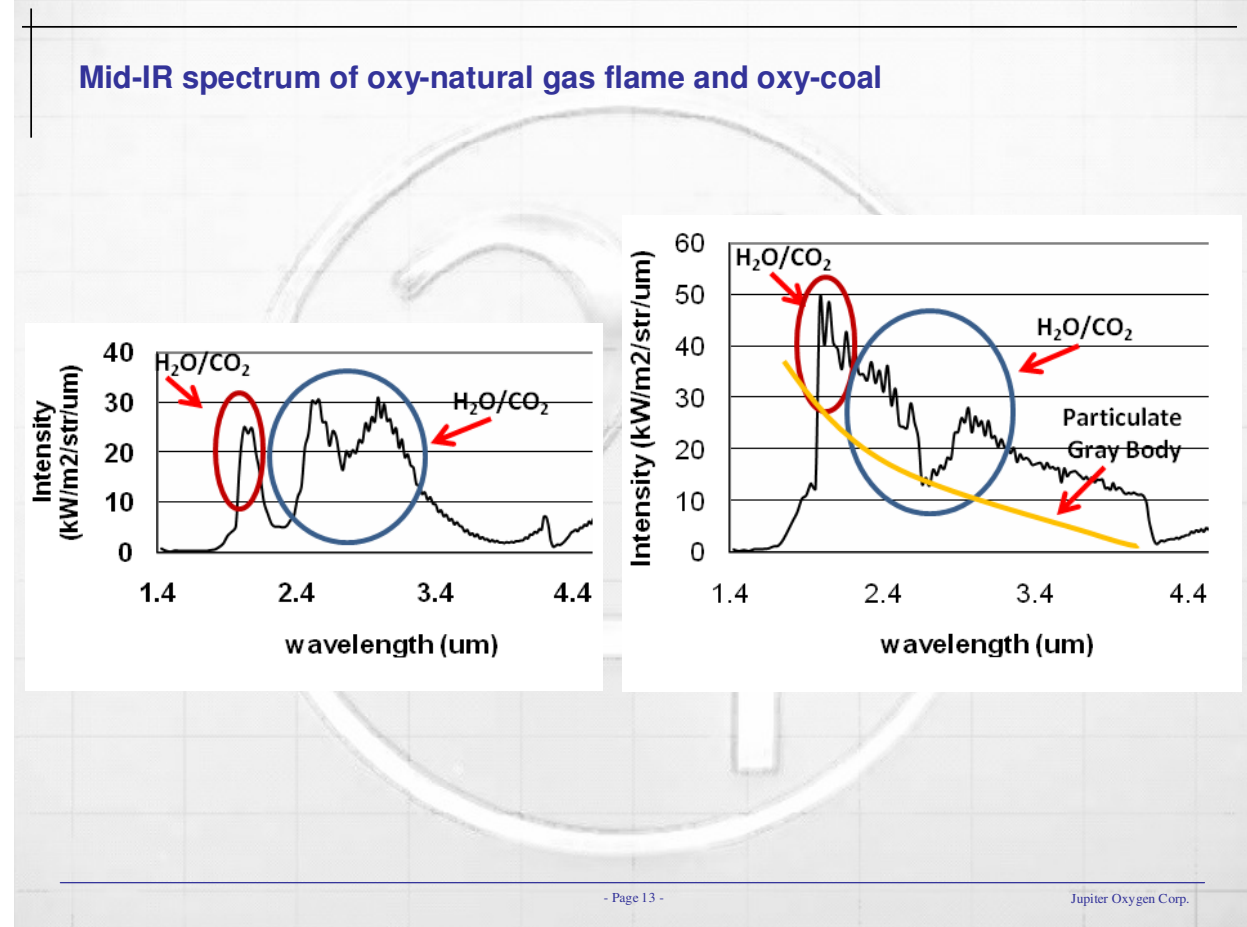

Figure 34: Mid-IR spectrum of oxy-natural gas and oxy-coal flames

\section{SUMMARY OF RETROFIT STEPS}

Jupiter Oxygen's method for modifying an existing power plant for Jupiter's undiluted high flame temperature oxy-combustion process with $\mathrm{CO}_{2}$ capture can be a purely retrofit process, and does not involve rebuilding of the power plant itself. For this reason, as well as efficiency and fuel savings benefits, it is an economically desirable approach.

There are seven fundamental physical retrofit steps as outlined below.

1. Oxygen Plant

An oxygen plant will be purchased and installed on-site. Currently, that plant would be a cryogenic air separation unit (ASU), which is a mature, commercialized technology. It is expected that future oxygen plants could 
use a form of membrane technology, and be far less costly both in terms of capital and operating costs. The present cryogenic approach has shown steady improvement over the past decade, and that improvement is expected to continue.

A first step is to identify the location for the ASU on the grounds with enough open space. Power plant operations should not be disturbed during ASU construction since the ASU is not associated with the conventional operation of the power generation unit. The ASU can be connected to the boiler to feed oxygen to the burners when the boiler would be shut down for high flame temperature oxy-combustion burner installation. It is anticipated that this will done during approximately the same period as a standard boiler shutdown for burner change-over and other maintenance.

A high efficiency state of the art current cryogenic. ASU is expected to produce oxygen at $97.5 \%$ purity. Nitrogen from the air is vented back to the air, and argon is the predominant remaining tramp gas with the oxygen. The production of oxygen is the most energy intensive process in the power plant. For that reason, there has been a continuous push for improving the methods for producing oxygen. In 2000, the common number being used for oxygen production was approximately $240 \mathrm{kWh} / \mathrm{ton}$ $95 \% \mathrm{O}_{2}$. By 2005 , the number was approximately $210 \mathrm{kWh} /$ ton $97.5 \% \mathrm{O}_{2}$. In general, there is very little difference in energy intensity for the production of $95 \% \mathrm{O}_{2}$ versus $97.5 \% \mathrm{O}_{2}$ because the $\mathrm{N}_{2}$ component has a much larger difference in boiling point from $\mathrm{O}_{2}$ than argon does. So, when the $95 \% \mathrm{O}_{2}$ has the $\mathrm{N}_{2}$ removed, it becomes approximately $97.5 \% \mathrm{O}_{2}$ with argon as the predominant remaining tramp gas. In 2012, $\mathrm{O}_{2}$ vendors are reportedly claiming ASUs will produce $97.5 \% \mathrm{O}_{2}$ while using only 180 $\mathrm{kWh} /$ ton. Advanced cryogenic ASUs would be designed specifically for oxy-combustion by matching the $\mathrm{O}_{2}$ exit pressure to the inlet pressure of the boiler. The advantage of nearly zero $\mathrm{N}_{2}$ in the $\mathrm{O}_{2}$ is that there will be very little NOx produced in the flame, and that negates any need for gas cleanup. Of course, cost effectiveness would be part of the engineering for any retrofit project.

The possibility of further advances using membranes indicates that the specific power may be reduced to near $150 \mathrm{kWh} /$ ton of near $100 \% \mathrm{O}_{2}$. . This would produce gains in efficiency in a number of ways including a reduction in total mass flow, a reduction in operating costs, and no need for further treatment if the combustion products must be clean enough for EOR.

2. $\mathrm{CO}_{2}$ Capture System 
An integrated pollutant removal (IPR) ${ }^{\circledR}$ system would be installed at roughly the same time as the ASU. Power plant operations would not be disturbed during this step until integration is done through a direct connection to the power plant exhaust. Until the system is cut over to the IPR system, the existing power plant unit would operate as originally designed. When the boiler is shut down to add the oxygen firing sections, both the ASU and IPR would be plumbed in. As with the ASU, there would be space needed for the installation of the IPR system.

The IPR system cleans up and compresses the combustion products as needed for $\mathrm{CO}_{2}$ sequestration. There are changes in exited flue gas temperature and pressure, heat exchangers removal of water and Sox, and filter removal of $\mathrm{Hg}$ and particulate, resulting in transport ready captured $\mathrm{CO}_{2}$.

There are multiple means of disposing of $\mathrm{CO}_{2}$. The use of $\mathrm{CO}_{2}$ in enhanced oil recovery (EOR) or coal bed methane recovery (ECBM) requires higher purity of these combustion products. To obtain the higher purity for CCUS (Carbon Capture, Utilization, and Storage) requires more energy and loses some of the $\mathrm{CO}_{2}$ as higher purity is achieved through various forms of distillation. A utility must decide the purity specification required for its purposes. CCS Co-sequestration (the sequestration of the $\mathrm{CO}_{2}$ and all of the tramp gases) may be available. Using a value added approach to disposal with CCUS and $\mathrm{CO}_{2}$ as a saleable product requires carefully determining the added cost for further purification.

With ultra-low NOx at combustion, limited fuel nitrogen, and planned avoidance of air infiltration, no SCR or similar equipment would be needed for NOx control even if the combustion products are released to the atmosphere.

For coal firing, the $99 \%$ Sox, $90 \%$ mercury and $99 \%$ particulate removal allow any uncaptured $\mathrm{CO}_{2}$ to be emitted to the atmosphere without violation of non- $\mathrm{CO}_{2}$ air pollution laws if positive/balanced pressure is maintained on the boiler and scrubbing is part of the IPR for coal. Using natural gas in a positive pressure/balanced draft boiler avoids any treatment for the combustion products.

The IPR system consists of unit processes designed to provide the purity of $\mathrm{CO}_{2}$ needed with energy recovery at each step to avoid high parasitic power. In the case of oxy-natural gas combustion, the IPR system is only needed if the $\mathrm{CO}_{2}$ is being captured. In that case, the IPR system consists of heat exchange to move heat from the exhaust products to the working fluids in the steam system such as the condensate. There is no need for any treatment of the oxy-natural gas system other than compression with energy recovery for both sensible and latent heat. If 
the system is oxycoal, particulate removal and a scrubber to remove the SOx from the system are included in the first stages. At each compression step, more heat is recovered from any of the IPR compressors.

The IPR system combined with high flame temperature oxy-combustion provides another staged option in that the power plant can adjust the amount of combustion product treated to meet regulations. For instance, if the power plant must produce an amount of $\mathrm{CO}_{2} / \mathrm{MW}$ that is half of what would be produced without treatment, the plant can choose to treat only half of the flue gas. That would reduce the capital and operating cost and still meet the regulatory requirements. If the requirements become more stringent at a later date, another train can be added to the IPR system, and more of the combustion products can be treated. In like manner, multiple trains can be built in to enhance maintenance.

In addition, heat recovery from ASU and IPR compressors can resulted in a $8-9 \%$ fuel savings assuming sufficient heat can be integrated into power plant systems as well as to pre-heat the oxygen.

Water recovered from the IPR can be used for power plant usage with water treatment, and exceeds boiler feedwater requirements.

3. Special oxyfuel burners and a control system, designed for Jupiter's high flame temperature oxycombustion process, are installed. This allows lower fuel usage and low excess oxygen combustion. If necessary for NOx control, special, low-NOx burners are used. Water wall and steam temperatures remain the same as with air firing unless otherwise desired, although the oxyfuel flame is at a much higher temperature and undiluted. This step can be done during approximately the same period as for normal burner change-over.

4. During step 3, fans and ductwork can be modified as needed to ensure recirculation of flue gases to [a] feed the coal without air (assuming coal is the fuel rather than natural gas) and [b] balance heat transfer in the radiant and convective regions to match pre-existing conditions if desired. Step 4 is considered because there is [a] far greater radiant heat transfer than with air firing due to the much higher flame temperature and [b] only approximately $25 \%$ of the gases created at combustion since oxygen is used instead of air. Introduction of flue gas recirculation to balance heat transfer occurs at a sufficient distance and direction from the flame to maintain the high flame temperature process. For some boilers, balancing heat transfer may be more economical if there is a heat boost in the convective zone, using enhanced superheat, reheat, or other heat boost approach. Some existing fans are discontinued since they are no longer needed, with some savings of current parasitic power. 
5. Also during step 3, the boiler is made relatively airtight, and the pressure may be balanced or made slightly positive to minimize the introduction of nitrogen, thereby avoiding higher NOx levels and minimizing efficiency losses which occur when nitrogen is heated. Air tightness is done employing practical measures, such as ductwork and boiler casing inspections, with repairs and sealing done as needed. Step 5 also can be important for some $\mathrm{CO}_{2}$ product specifications, in order to avoid unnecessary $\mathrm{CO}_{2}$ clean-up due to air infiltration.

6. Note that high temperature materials do not need to be added except for burner blocks unless changes heat transfer surfaces provides a cost effective means to improve efficiency and/or balance heat transfer.

7. If $\mathrm{CO}_{2}$ purity greater than $95 \%$ is required, a $\mathrm{CO}_{2}$ purification unit using distillation is incorporated with the IPR process, as described above.

Test data and modeling indicate high flame temperature oxy-combustion has gross boiler combustion fuel savings due to improved radiant heat transfer. A heat boost may be used in the convective zone to balance heat transfer by providing some energy there rather than entirely through combustion in the radiant zone. Using the natural gas testing with air firing and high flame temperature oxy-combustion in the test unit, a total fuel savings $4.58 \%$ was seen at combustion.

\section{COMPARISON OF JOC HIGH FLAME TEMPERATURE OXY- COMBUSTION/IPR TO OTHER OXY-COMBUSTION APPROACHES}

Looking at the options that are available with the Jupiter/IPR approach we can see how those options compare with other oxyfuel approaches. Conventional oxy-combustion systems rely on balancing the heat transfer in the system by producing the equivalent of "synthetic air" and keeping the heat transfer in the system similar to that found in an air fired system. In this low flame temperature approach with flame temperature in the same range as air firing, vendors attempt to match the heat transfer found in each section of the boiler during air firing. This is difficult to do because the combustion products are different between air firing and oxy firing. 


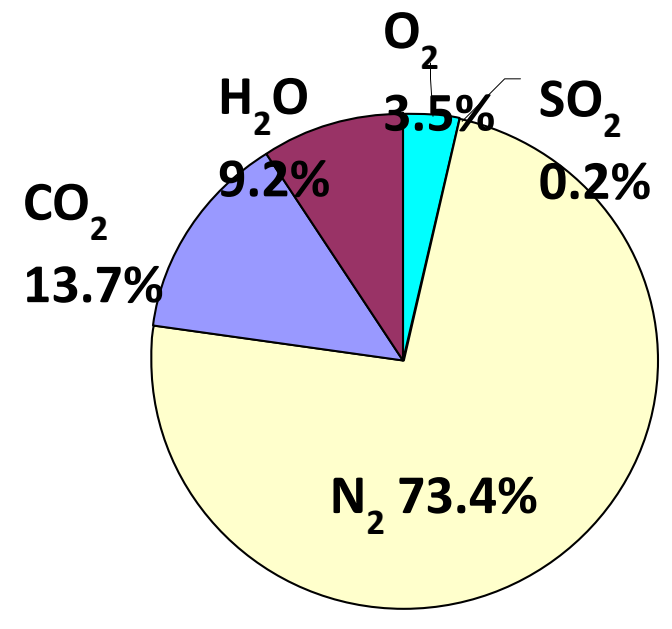

air-fired flue gas

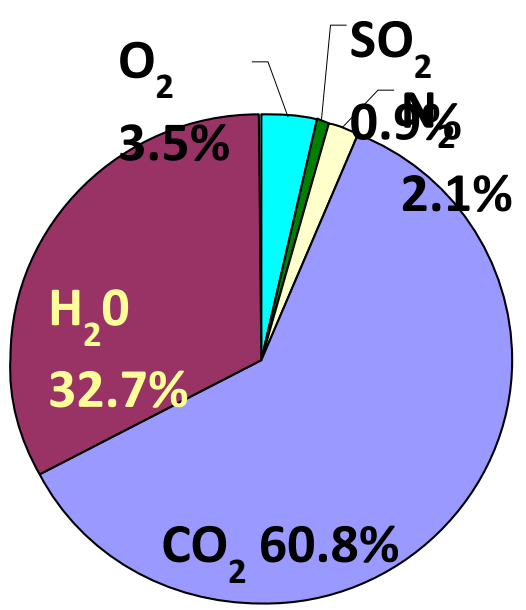

oxy-fired exhaust

Figure 35: Percentage of gases in combustion products comparing air firing with oxy firing

As can be seen in the figure above, air combustion products are made up of, predominantly nitrogen while oxyfuel combustion products are predominantly $\mathrm{CO}_{2}$ and $\mathrm{H}_{2} \mathrm{O}$. The difference in heat transfer properties makes it difficult to match the heat fluxes when the heat transfer surfaces are kept the same and the combustion products change. This balancing act becomes particularly difficult when natural gas is used as the fuel because it produces a non-luminous flame, whereas coal produces a luminous flame due to the coal and ash particles in the combustion system.

A separate 2012 Jupiter Oxygen-Reaction Engineering International showed that high flame temperature oxy-combustion makes it feasible to convert coal fired power plants to use natural gas as the fuel because of the improved radiant heat transfer due to the high flame temperature. 


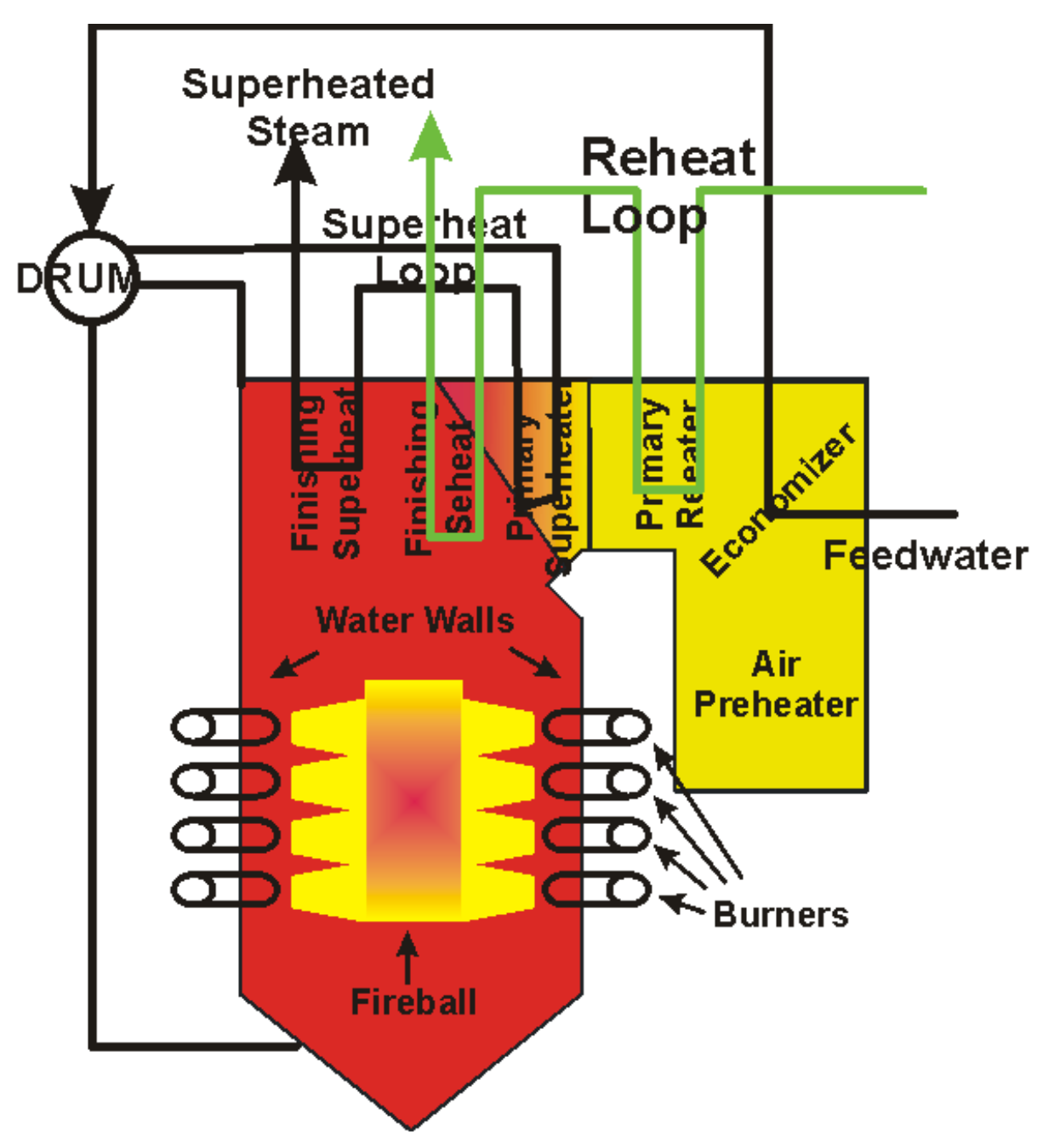

Figure 36: A typical coal fired boiler showing the various heat transfer zones.

Figure 36 shows a typical air fired boiler with the water walls, finishing superheater, and finishing reheater in the radiant zone, the primary superheaters and reheaters in the convective zone, and the economizer and air preheater in the last sections of the convective back pass. Knowing that the steam turbines have been defined during the initial design of the air fired system, it is important to ensure that the steam at the turbine entrance meets the requirements for mass, temperature, and pressure. Mass is generated at the water walls. That means that the first rule for the retrofit is that the heat into the water walls is virtually identical to that for the air fired system. Since the heat transfer properties of the different combustion products are different, there will not be enough enthalpy left in the combustion products to finish off the superheat and reheat temperatures without some adjustment to the system. In the high flame temperature approach, the heat transfer to the water walls is maintained by controlling the fuel and oxygen ratio, recirculation as needed, and the superheat and reheat are maintained by a temperature boost in the convective zone if needed. 


\begin{tabular}{|l|l|l|}
\hline & BTU/hr & $\begin{array}{l}\text { Fraction } \\
\text { of total }\end{array}$ \\
\hline Water boiling & $1,502,695,101$ & 0.46 \\
\hline Steam superheating & $1,041,635,780$ & 0.32 \\
\hline Steam reheat & $496,694,752$ & 0.15 \\
\hline Economizing & $229,305,500$ & 0.07 \\
\hline
\end{tabular}

Figure 37: Distribution of heat in the various zones

Figure 37 shows the details of the heat transfer that takes place in a typical boiler. If any of these values differs substantially, the steam flow will not meet the requirements of the steam turbines. Most of the heat is deposited in the radiant zone (including the water walls and the radiant pendent superheaters and reheaters). It is the radiant energy that can be fine-tuned with the high flame temperature oxyfuel system.

\section{DESIGN CONSIDERATIONS}

The implementation of oxy-combustion has important decision points for engineering firms to actualize in both retrofit and Greenfield production. The open area for engineering will require both broad decision areas concerning potentially stranding assets or making investments to meet regulations, as well as specific design issues such as feed water inter cooling, and interactions with steam turbines, ducting design, auxiliary power requirements, as well as plant life expectancy as to whether to upgrade any components.

It is impractical to take all of the detailed design decisions into consideration without actually designing the plant. However, it is possible to model the systems at a component level to illustrate major differences within broader oxycombustion approaches.

As noted earlier in the document, the heat transfer in an oxy-combustion system will be inherently different from that in an air fired system, as well as different for high and low flame temperature oxy-combustion. Because of the differences, the heat transfer from the flame must be matched to a specific set of existing heat transfer surfaces in multiple zones simultaneously. In the high-temperature approach, the efficient deposition of heat in the radiant zone may leave insufficient enthalpy to provide superheat and reheat without further modification. Both of these issues can be overcome by adding heat to the superheat and reheat sections of the boiler. In standard systems, there is a provision for attemperation of the superheat and reheat to reduce their temperatures when they have 
higher temperatures than are allowed. In the case of high flame temperature oxy-combustion, different approaches to ensure balance of the heat transfer in each region include:

[a] flue gas recirculation away from the flame to reduce radiant zone flue gas residence time.

[b] energy introduced directly within the superheat and reheat zones in the boiler;

c] external heaters (similar in nature and size to package boilers) using oxy-combustion to heat the superheat and reheat streams after they have left the main boiler.

d] increased or otherwise changed heat transfer surfaces

These approaches are able to provide the superheat and reheat needed to match temperatures at the existing turbines with balanced heat transfer.

Duct modifications: Both approaches require modifications to the duct systems in retrofits. In both cases the systems will be delivering different quantities and types of gases than the original design. The ducting will also have to be better sealed than in a standard boiler (to prevent air infiltration). The ducts also have to recirculate flue gas for motivating flue gas as well as tempering the flame release rate in an existing boiler. Fan modifications (listed below) are subject to the same restrictions.

Fan modifications: Both oxy-combustion systems require modifications to the fan systems to achieve the required gas flows (considering the difference in flows and gas properties). This will require replacement or upgrade in retrofits.

Oxygen plant $/ \mathrm{O}_{2}$ infrastructure: Both systems require the addition of an oxygen plant (air separation unit) and oxygen upgrades to the systems that will carry oxygen. Oxygen has properties that require it to be handled differently from other gases, and there will be required upgrades to the gas handling infrastructure in the presence of concentrated oxygen.

Burner Modifications: The properties of the gases being handled in the burners and the motive gases that will require modification/replacement of existing burners. In almost every studied case, the utility would be better served by replacing existing burners in retrofit systems and new designs needed for Greenfield systems.

$\mathrm{CO}_{2}$ treatment: Both approaches require $\mathrm{CO}_{2}$ treatment for cleaning and compression of the $\mathrm{CO}_{2}$ for alternate use (EOR/CBM) or sequestration. The amount of treatment will be dependent on the ultimate disposition of the $\mathrm{CO}_{2}$ and the properties of the fuel. There are multiple types of treatment systems that have different approaches based on the end use of the $\mathrm{CO}_{2}$. 
Boiler Sealing: Infiltration of air into the combustion system produces tramp gases in the exhaust that is difficult to separate from the $\mathrm{CO}_{2}$. It has been shown to be advisable that preventing the infiltration is important. For new designs and some retrofits, a use of nearly balanced but slightly positive pressure in the system is preferred to avoid infiltration. In the case of positive or negative pressure a well-sealed boiler will minimize $\mathrm{CO}_{2}$ treatment.

Steam Turbine Upgrade: The upgrading of older steam turbines is a good way to increase performance in retrofit systems. Existing coal fired plants were, generally, designed before the advent of advanced simulation tools. For that reason, many manufacturers offer upgrades to their older steam turbines. While the plant is down for the oxy-combustion changes, it is reasonable to look at other improvements that can be available. This is shown as optional for both approaches.

Boiler Enhancement: If a boiler was originally designed for operation in negative pressure mode (as most coal fired plants were originally designed), it can be an important upgrade to modify them to run in positive pressure mode. This will prevent air infiltration but will require an engineering study to determine the modification needed for this upgrade. If the system is a new design, the increased heat transfer in the radiant zone due to a hotter flame in the high-temperature approach has the possibility to reduce the size of a boiler.

\section{DESIGN TYPES}

There are a number of specific design considerations that have been examined for oxy-combustion systems. A simple block diagram of an air fired system is shown in Figure 38. In this system, the air (containing significant inert gases $\mathrm{N}_{2}$ and $A R$ ) runs through the boiler zones, carrying energy required to the representative zones. Each of these zones has a requirement to balance the amount of heat going through the zone. 


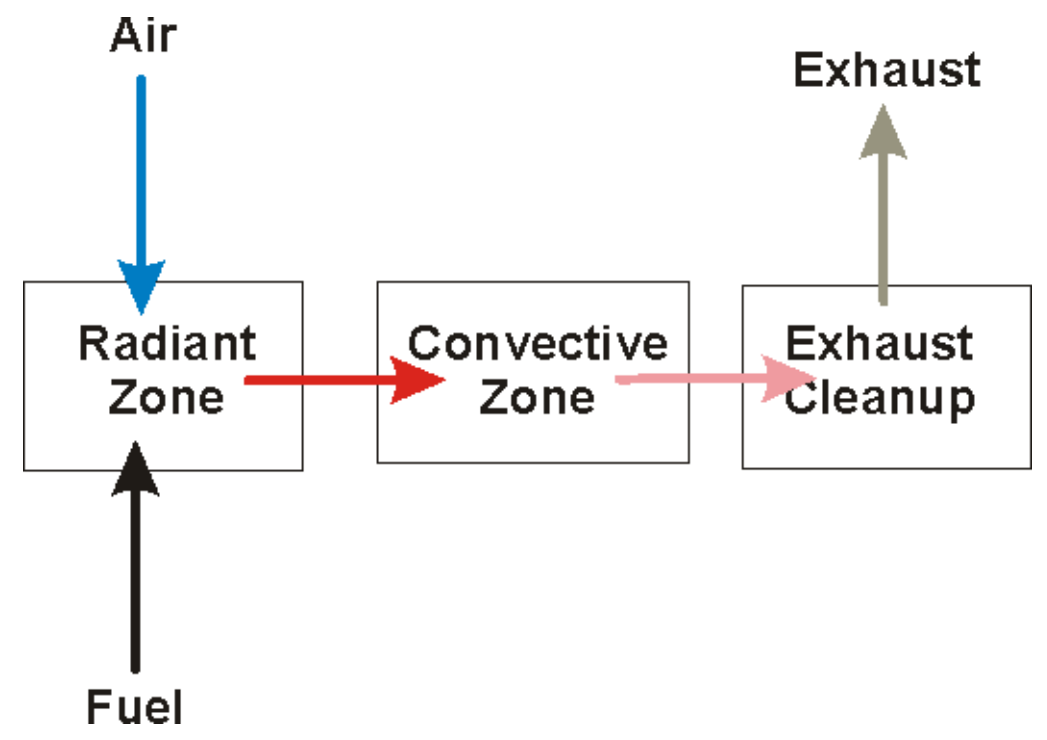

Figure 38: Block diagram of an air-fired coal system.

As shown in Figure 39, a simple first generation low-temperature oxyfuel system is shown with all of the exhaust gas going through cleanup. The reason for the cleanup is the potential for corrosion if SOx is allowed to stay high when using a high-sulfur coal. It also keeps the recycle gas relatively dry to avoid problems with coal motivation.

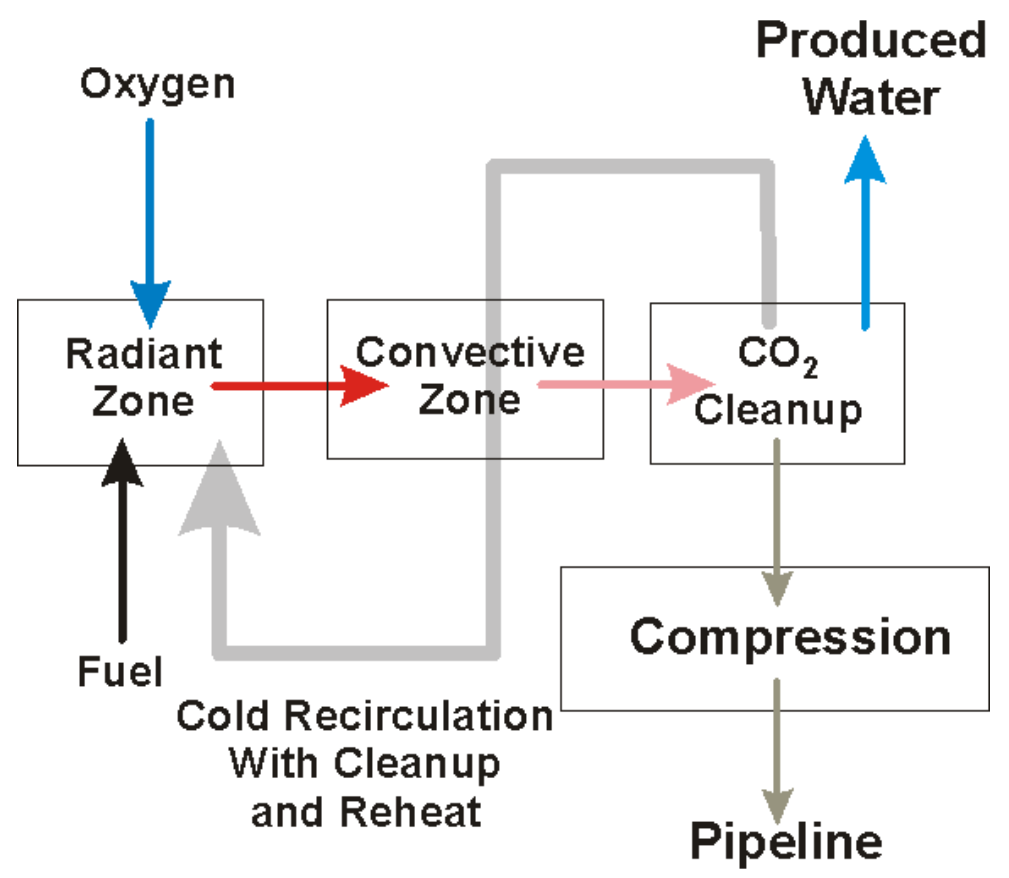

Figure 39: Block diagram for an oxyfuel system with cold recirculation.

The cold recirculation approach is a simple way to be sure that there is no problem in the recirculation system. Unfortunately, this approach also robs the power unit of heat. The heat can be partially recovered by using the approach of 
using feedwater for cooling (as patented in the IPR method), however, each case should be evaluated and cold recirculation should not be used unless needed (due to high sulfur content). A better approach, when the coal sulfur level permits, is to use the second generation design shown in Figure 40. In this approach, a hot recycle stream is used with only the motive gas being cleaned (mostly the removal of condensable water vapor).



Figure 40: Hot recycle with cold motive gas.

With a redesign of the motive system, an improvement is to go to full hot recycle, including the motive gas. This design requires a change in the motive system as well as in the pulverizers to prevent condensation that causes problems with the system Figure 41. 


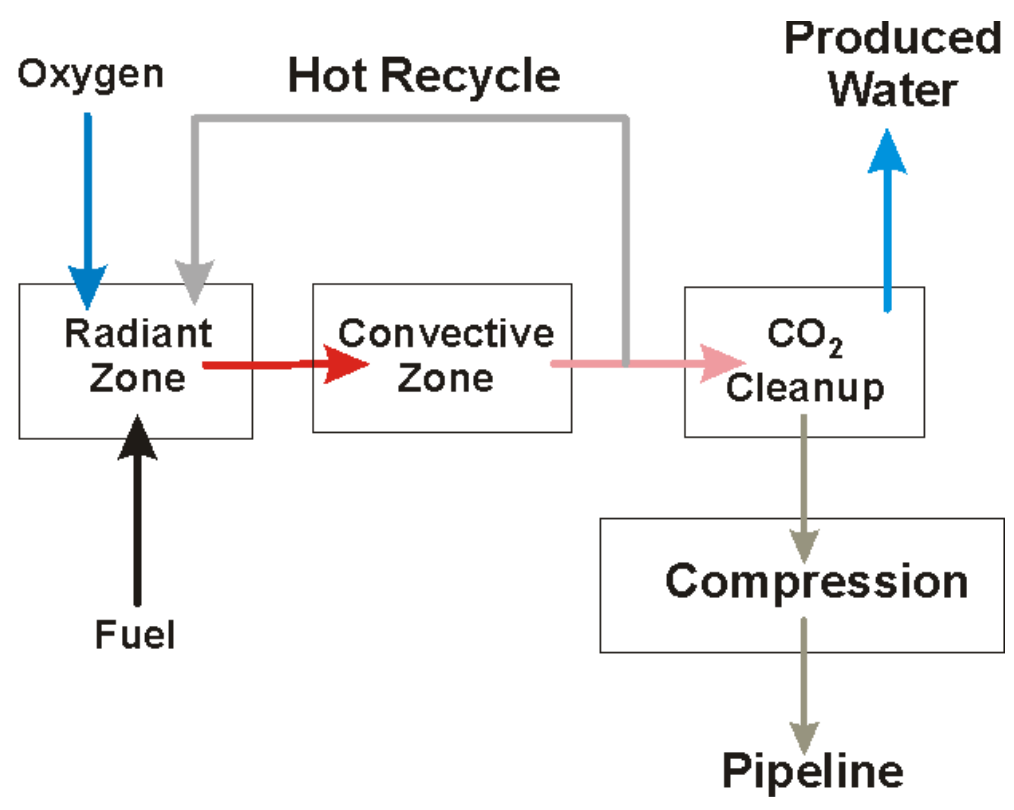

Figure 41: Full hot recycle with hot recycled motive gas

Another approach is to use the hot recycle for motive only and avoid any more dilution of the coal fuel as shown in Figure 42. This helps provide a hightemperature flame.

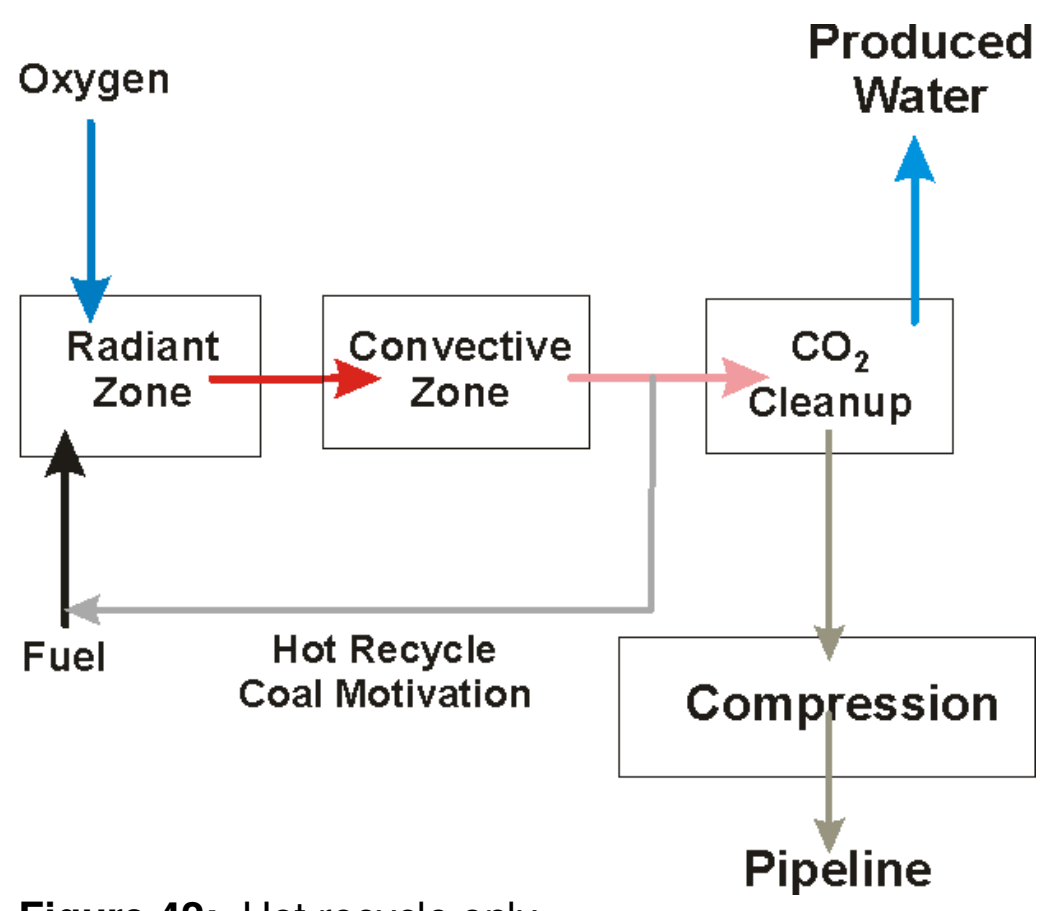

Figure 42: Hot recycle only. 
Another variation of the system is to use the oxygen and the fuel and then add the booster heat (internal or external) to balance the superheat and reheat temperatures (as shown in Figure 43).

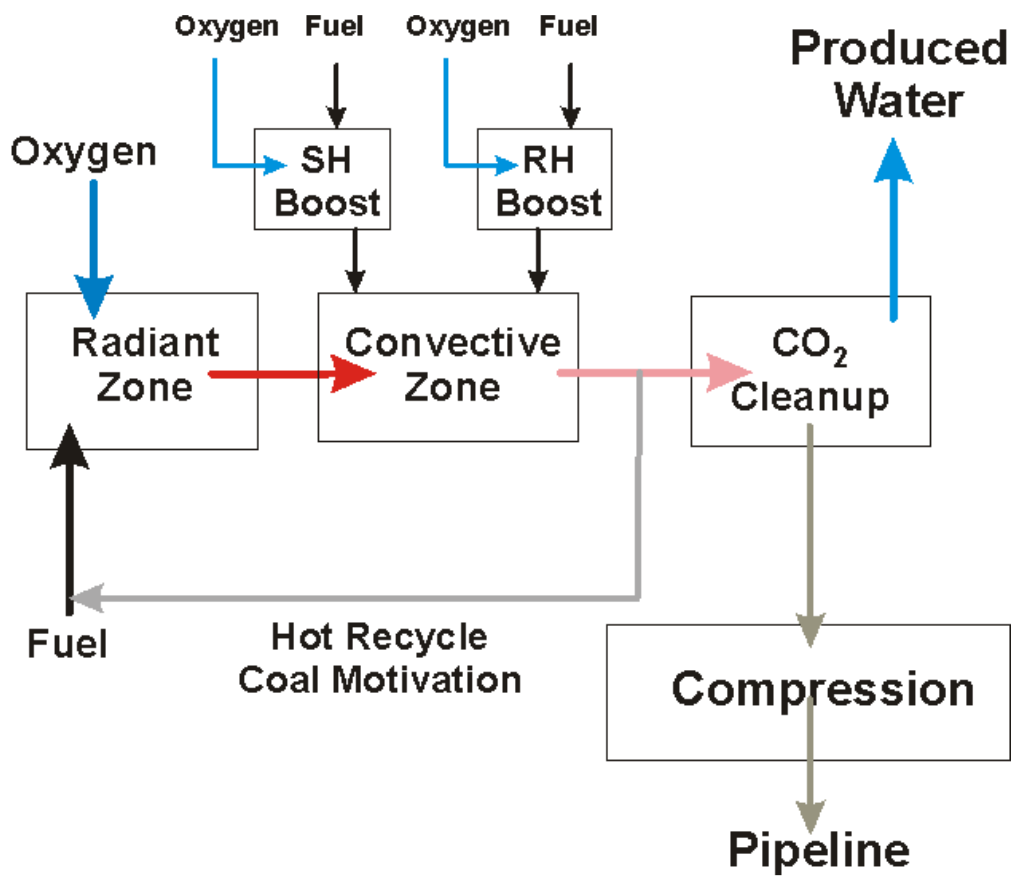

Figure 43: Advanced oxycoal system.

A common issue for each of the oxy-coal approaches is the need for motive gas to move the pulverized coal into the boiler. However, if oxygen is combined with natural gas the result is a high temperature flame (with enhanced radiant capabilities) and a greatly simplified system. In this approach there is no need for any motive gas and the combustion products are clean enough to be released into the environment if CCS is not available or not needed. This approach is an intermediate approach that may allow a utility to retrofit a boiler at the lowest cost while gaining experience with oxy-combustion systems, and meeting environmental requirements. If a utility finds it advantageous, the project engineering can consider steps to allow future implementation of an oxy-coal system if prices of fuels warrant the change. This approach could not have been foreseen a few years ago when it seemed that natural gas would continue to be an expensive and scarce commodity. The expansion of the NG industry in the last few years has made this a possibility as an intermediate step toward oxycoal systems and CCS as well as CCUS. The other technology that makes this possible is the development of the high-temperature oxy-combustion system that can generate the necessary radiant heat transfer from natural gas to provide sufficient heat transfer to the radiant zone to boil designed quantities of water. 


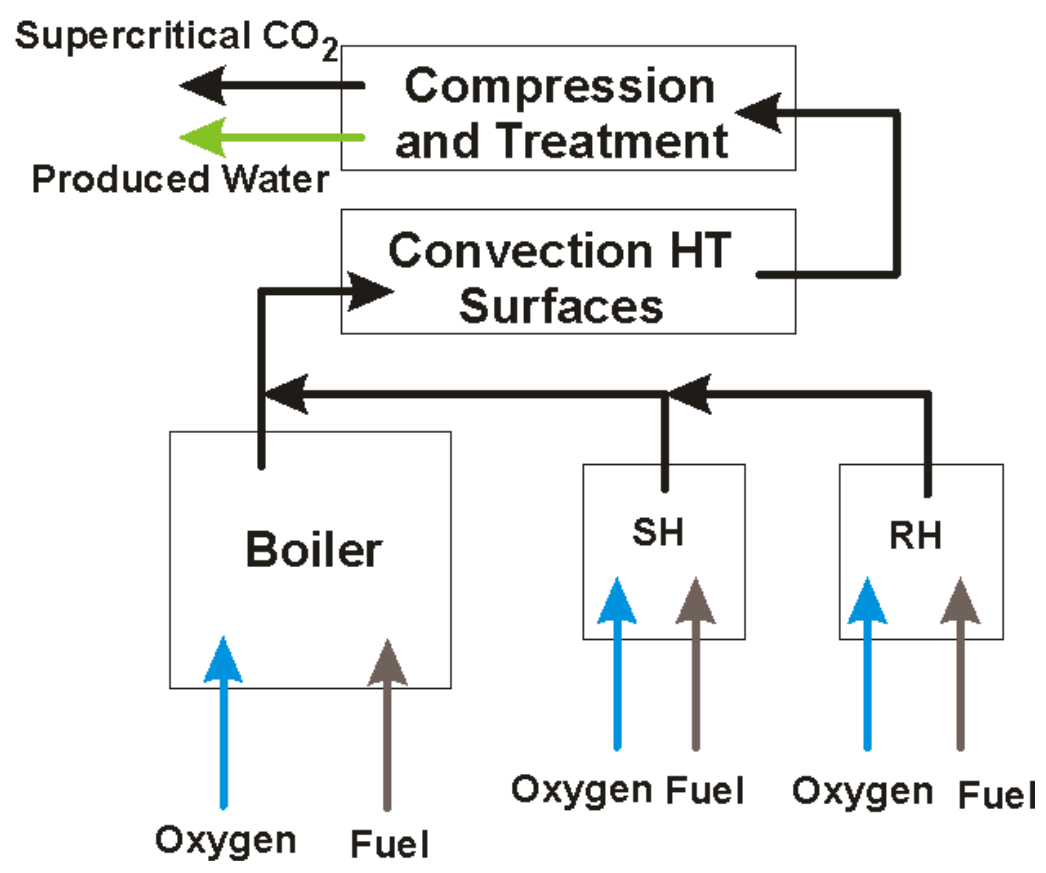

Figure 44: Potential Advanced Greenfield oxyfuel system.

As shown in Figure 44, high flame temperature oxy-combustion can completely eliminate the need for coal motive gas by using natural gas or other combustible gas as the motive gas for coal. In this case, all of the flowing gas/solid system is fuel. The mixed fuel approach will produce a combination of high-temperature flames and high luminosity due to the inclusion of radiating coal, ash, and slag particles. The high-luminosity ONG/coal (ONGC) flame will provide very high heat transfer from the flame to the boiler walls. This also leads to the possibility of direct power generation under the high-temperature, high-luminosity flame conditions by using an MHD topping unit with a supercritical bottoming steam unit for next generation power generation systems. The use of a topping unit increases the useable enthalpy that can be extracted from the system under low entropy conditions (higher temperature direct use) and could improve exergy extraction. 
7. Evaluation of a retrofit to Connesville \#5

Jupiter Oxygen in cooperation with Wyatt Enterprises, LLC completed an evaluation to retrofit the Connesville power plant unit\# 5 to the Jupiter Oxygen high flame temperature oxy-combustion process with JOC/NETL IPR carbon capture and compression to pipeline/sequestration pressure. Oxygen at $97.5 \%$ purity is supplied to the burner systems via a high efficiency state of the art cryogenic air separation process. The flue gas compression process for carbon capture utilized three stages of Ramgen shock wave type compression with interstage cooling and heat recovery to the boiler feed water system. The study assume that flue gas purity from the IPR process is sufficient for carbon sequestration and no further purification processes are employed.

The three approaches for balancing heat transfer between the radiant and convective zones are: [a] increase in flue gas recycle away from the burners so that the high flame temperature is not adversely affected, [b] add or increase superheater and/or reheater in the convective zone, or [c] a combination of [a] and [b]. For this Connesville analysis, flue gas recycle was minimized to that required to motivate the coal feed to the boiler as a modeling experiment. As expected, superheated and reheated steam temperature from the main boiler system falls short of the required temperature as defined by the air fired case. Therefore a booster superheater and reheater are added to the process to adjust the final steam temperatures to match the air fired case. This process retrofit evaluation shows the following results for the Jupiter Oxygen high flame temperature oxycombustion process.

- The parasitic power load for oxygen production is $11.1 \%$ of the facility gross power output.

- The parasitic power load for carbon capture is $11.2 \%$ of the facility gross power output.

- The net increase in parasitic load (including oxygen generation, carbon capture, and savings in base utilities) is $22.0 \%$ of the facility gross power output.

- The fuel saving at combustion in the main plant boiler compared to air firing is $15.5 \%$, and the net fuel savings including fuel usage for the booster superheater and reheater is $2.7 \%$.

- Waste heat recovery from the carbon capture process coolers is equal to $3.3 \%$ of the facility gross power output.

Wyatt Enterprises, LLC also evaluated the carbon capture capital cost downstream of the boiler system of the Connesville \#5 power plant for the JOC/NETL IPR process compared to the NETL's Advancing Oxy-combustion Technology for Bituminous Coal Power Plants 2012 final report. The Wyatt evaluation considers the case that the Connesville \#5 power plant has been converted to oxy-combustion and then evaluates the reported capital cost of 
the carbon capture equipment vs. the JOC/NETL estimate of the carbon capture equipment. In this evaluation corrected to 2012 dollars the JOC/NETL carbon capture equipment is shown to be $10 \%$ less than the capture system capital costs reported in NETL's Advancing Oxy-combustion Technology for Bituminous Coal Power Plants 2012 final report.

8. Modular boiler design

Jupiter Oxygen and the NETL project team created a module boiler design for new build high flame temperature oxy-combustion boilers which has been patented. See patent section below. 
9. Patents and patent applications

i. Oxy-combustion Combustion System with Integrated Pollution Removal

The subject matter of the patents/patent applications is for the Oxy-combustion Combustion System with Integrated Pollution Removal covers integrated oxygen fueled combustion system and pollutant removal system that reduces flue gas volumes, eliminates $\mathrm{NO}_{x}$ and captures condensable gases. The system includes a combustion system with at least one burner configured to substantially prevent the introduction of air. Oxygen is supplied at a predetermine purity greater than 21 percent to the combustion system along with a carbon based fuel. Oxygen and fuel are fed into the furnace in controlled proportion to each other to produce a flame temperature in excess of $3000^{\circ} \mathrm{F}$. and a flue gas stream containing $\mathrm{CO}_{2}$ and other gases. The flue gas is substantially void of non-fuel borne nitrogen containing combustion produced gaseous compounds. The oxygen content of the comburent can be allowed to become greatly higher than that of low flame temperature oxycombustion, thereby providing design engineers with the ability to use oxygen content as an additional degree of design flexibility.

The pollutant removal system includes at least one direct contact heat exchanger for bringing the flue gas into intimated contact with a cooling liquid to produce a pollutant-laden liquid stream and a stripped flue gas stream. The pollutant laden liquid stream is discharged while the stripped flue gas stream is processed by a series of heat exchangers and compressors to cool and compress the flue gas in order to separate the stripped flue gas stream into non-condensable gases and condensable gases. The condensable gases, in large part $\mathrm{CO}_{2}$, are condensed into a substantially liquid state and sequestered. The non-condensable gases are filtered and captured in an accumulator.

The patents and patent applications covering the Oxycombustion Combustion System with Integrated Pollution Control are provided below.

\begin{tabular}{|l|l|l|l|c|l|}
\hline COUNTRY & APP. NO. & $\begin{array}{l}\text { FILING } \\
\text { DATE }\end{array}$ & PATENT NO. & $\begin{array}{l}\text { GRANT } \\
\text { DATE }\end{array}$ & STATUS \\
\hline Australia & 2006332510 & $27-$ Dec-06 & 2006332510 & $21-J u n-12$ & Issued \\
\hline Mexico & MX/A/08/008499 & $27-$ Dec-06 & 299084 & $9-$ May-12 & Issued \\
\hline South Africa & $2008 / 05838$ & $27-$ Dec-06 & $2008 / 05838$ & $29-J u l-09$ & Issued \\
\hline
\end{tabular}




\begin{tabular}{|c|c|c|c|c|c|}
\hline $\begin{array}{l}\text { United States of } \\
\text { America }\end{array}$ & $11 / 306,437$ & 28-Dec-05 & $8,087,926$ & 3-Jan-12 & Issued \\
\hline Canada & $2,635,611$ & 27-Dec-06 & & & Pending \\
\hline Eurasian Patent Office & 200870121 & 27-Dec-06 & & & Pending \\
\hline Japan & & 27-Dec-06 & & & Pending \\
\hline Japan & $2008-548834$ & 27-Dec-06 & & & Pending \\
\hline Mexico & $\mathrm{MX} / \mathrm{A} / 12 / 005433$ & $27-$ Dec-06 & & & Pending \\
\hline Republic of Korea & 10-2008-7015853 & 27-Dec-06 & & & Pending \\
\hline Australia & 2012202742 & 27-Dec-06 & & & Published \\
\hline China & 200680052837.4 & 27-Dec-06 & & & Published \\
\hline European Patent Office & 06846819.8 & 27-Dec-06 & & & Published \\
\hline European Patent Office & 12004155.3 & 27-Dec-06 & & & Published \\
\hline Hong Kong & 08110363.0 & 27-Dec-06 & & & Published \\
\hline India & 5638/DELNP/2008 & 27-Dec-06 & & & Published \\
\hline $\begin{array}{l}\text { United States of } \\
\text { America }\end{array}$ & $13 / 340,198$ & 29-Dec-11 & & & Published \\
\hline PCT & PCT/US06/62624 & 27-Dec-06 & & & Expired \\
\hline
\end{tabular}

Table 11: Patent \& Patent Applications filed for oxy-combustion and IPR

ii. Module Based Oxy-combustion Boiler

The subject matter of the patents/patent applications for the module based boiler system relates a plurality of independent, serially configured oxy-combustion boilers for producing steam from water. The boilers are configured with different energy transfer function from one another. A first or main boiler has a feed water inlet in flow communication with a plurality of tubes for carrying the water. The boilers are configured to substantially prevent the introduction of air.

The tubes of the main boiler form at least one water wall. Each boiler includes an oxygen supply for supplying oxygen having a purity of greater than 21 percent and preferably at least about 85 percent, a carbon based fuel supply for supplying a carbon based fuel and at least one oxy-combustion burner system. The burner system feeds the oxygen and fuel into the boiler in a near stoichiometric proportion to limit an excess of either the oxygen or the carbon based fuel to a predetermined tolerance. The tubes of each boiler are configured for direct, radiant energy exposure for energy transfer from the flame to the water wall tubes. In deference to traditional nomenclature, reference to water walls is intended to include all boiler tubes in a radiant zone even though the tubes may carry steam.

In one disclosed embodiment of the system, the second boiler is a superheat boiler and steam produced by the first boiler is fed directly to the superheat boiler. Steam exits the superheat boiler and flows to a main steam turbine. Alternately, the system can 
include a reheat boiler (which takes feed from the high pressure steam turbine exhaust), reheats the steam in an oxy fuel boiler similar to the main boiler, and feeds a reheat steam turbine. The energy transfer or heating function of each of the boilers is different from each of the other boilers. That is, in the main boiler, water is heated from a relatively low energy (enthalpy) value to saturated steam. In the superheat boiler (if used), the steam is further heated to superheated conditions. Then, in the re-heater, the exhaust steam from the high pressure turbine is reheated for feeding to a reheat steam turbine.

The boiler system can include a condenser configured such that steam exhausts from the high pressure steam turbine to one or more reheat steam turbines to optionally one or more low pressure turbines and on to the condenser. A preferred boiler system includes an economizer. The economizer has a gas side that receives combustion products ("exhaust gases" or "flue gases") from the boilers and a feed water side such that the combustion products preheat the boiler feed water prior to introducing the feed water to the main boiler. Following exhaust from the economizer, the exhaust gases can be used to preheat the oxidizing agent for the oxy-combustion combustion system, generally tying in to the exhaust gases system prior to any downstream exhaust gas processing treatment that may be desired. Increased power can be achieved by parallel groupings of modular boiler systems.

The oxy-combustion burners can be configured for many different types of fuel, such as natural gas, oil, coal and other solid fuels. When using a solid fuel, a portion of the exhaust gases (optionally mixed with oxygen) can be used to carry the solid fuel into the boilers. The fuel feed gases can be exhaust gases from downstream of the economizer.

The patents and patent applications covering the Module Based Oxy-combustion Boiler are provided below.

\begin{tabular}{|l|l|l|l|l|l|}
\hline COUNTRY & APP. NO. & $\begin{array}{l}\text { FILING } \\
\text { DATE }\end{array}$ & PATENT NO. & $\begin{array}{l}\text { GRANT } \\
\text { DATE }\end{array}$ & STATUS \\
\hline Algeria & 070613 & $1-$ Mar-06 & 5836 & $29-$ Aug-10 & Issued \\
\hline Armenia & 200701563 & $1-$ Mar-06 & 012129 & $28-$ Aug-09 & Issued \\
\hline Australia & 2010246395 & $1-$ Mar-06 & 2010246395 & $5-$ Jan-12 & Issued \\
\hline Azerbaijan & 200701563 & $1-$ Mar-06 & 012129 & $28-$ Aug-09 & Issued \\
\hline Belarus & 200701563 & $1-$ Mar-06 & 012129 & $28-$ Aug-09 & Issued \\
\hline China & 200680006419.1 & $1-$ Mar-06 & 200680006419.1 & $11-$ Jan-12 & Issued \\
\hline $\begin{array}{l}\text { Eurasian Patent } \\
\text { Office }\end{array}$ & 200701563 & $1-$ Mar-06 & 012129 & $28-$ Aug-09 & Issued \\
\hline Georgia & $10143 / 01$ & $1-$ Mar-06 & P4726 & 26-Jun-09 & Issued \\
\hline
\end{tabular}




\begin{tabular}{|c|c|c|c|c|c|}
\hline India & 2337/KOLNP/2007 & 1-Mar-06 & 248762 & 22-Aug-11 & Issued \\
\hline Japan & $2007-558259$ & 1-Mar-06 & 4917555 & 3-Feb-12 & Issued \\
\hline Kazakhstan & 200701563 & 1-Mar-06 & 012129 & 28-Aug-09 & Issued \\
\hline Kyrgyzstan & 200701563 & 1-Mar-06 & 012129 & 28-Aug-09 & Issued \\
\hline Liberia & PCT/LR07/00005 & 1-Mar-06 & PCT/LR07/00005 & 5-Sep-07 & Issued \\
\hline Mexico & $07 / 10601$ & 1-Mar-06 & 276414 & 7-Jun-10 & Issued \\
\hline Morocco & $\mathrm{PV} / 30234$ & 1-Mar-06 & 30297 & 1-Apr-09 & Issued \\
\hline New Zealand & 556054 & 1-Mar-06 & 556054 & 7-Nov-11 & Issued \\
\hline Philippines & $1-2007-501424$ & 1-Mar-06 & $1-2007-501424$ & 26-Jan-11 & Issued \\
\hline Republic of Korea & $2007-7020083$ & 1-Mar-06 & 0924797 & 27-Oct-09 & Issued \\
\hline $\begin{array}{l}\text { Republic of } \\
\text { Moldova }\end{array}$ & 200701563 & 1-Mar-06 & 012129 & 28-Aug-09 & Issued \\
\hline $\begin{array}{l}\text { Russian } \\
\text { Federation }\end{array}$ & 200701563 & 1-Mar-06 & 012129 & 28-Aug-09 & Issued \\
\hline Singapore & 200704960.4 & 1-Mar-06 & 133395 & 31-Mar-08 & Issued \\
\hline South Africa & $2007 / 07069$ & 1-Mar-06 & $2007 / 07069$ & 30-Sep-09 & Issued \\
\hline Tajikistan & 200701563 & 1-Mar-06 & 012129 & 28-Aug-09 & Issued \\
\hline Tunisia & SN.07.331 & 1-Mar-06 & 20044 & 20-May-09 & Issued \\
\hline Turkmenistan & 200701563 & 1-Mar-06 & 012129 & 28-Aug-09 & Issued \\
\hline Ukraine & 200709763 & 1-Mar-06 & 92601 & 25-Nov-10 & Issued \\
\hline $\begin{array}{l}\text { United States of } \\
\text { America }\end{array}$ & $11 / 070,177$ & 1-Mar-05 & $7,516,620$ & 14-Apr-09 & Issued \\
\hline $\begin{array}{l}\text { United States of } \\
\text { America }\end{array}$ & $12 / 399,411$ & 6-Mar-09 & $8,082,737$ & 27-Dec-11 & Issued \\
\hline Uzbekistan & IAP20070352 & 1-Mar-06 & IAP04365 & 31-May-11 & Issued \\
\hline $\begin{array}{l}\text { Antigua and } \\
\text { Barbuda }\end{array}$ & PCT/7/2007 & 1-Mar-06 & & & Pending \\
\hline Brazil & PI0606225.3 & 1-Mar-06 & & & Pending \\
\hline Canada & $2,593,766$ & 1-Mar-06 & & & Pending \\
\hline Ecuador & SP-12-11588 & 1-Mar-06 & & & Pending \\
\hline Grenada & & 1-Mar-06 & & & Pending \\
\hline Norway & 20074428 & 1-Mar-06 & & & Pending \\
\hline Oman & $87 / 2007$ & 1-Mar-06 & & & Pending \\
\hline Saint Lucia & & 1-Mar-06 & & & Pending \\
\hline Sri Lanka & 14554 & 1-Mar-06 & & & Pending \\
\hline $\begin{array}{l}\text { United Arab } \\
\text { Emirates }\end{array}$ & P611/07 & 1-Mar-06 & & & Pending \\
\hline Ecuador & SP-07-7571 & 1-Mar-06 & & & Published \\
\hline $\begin{array}{l}\text { European Patent } \\
\text { Office }\end{array}$ & 06736825.8 & 1-Mar-06 & & & Published \\
\hline $\begin{array}{l}\text { European Patent } \\
\text { Office }\end{array}$ & 12174108.6 & 1-Mar-06 & & & Published \\
\hline Hong Kong & 08113991.4 & 25-Dec-08 & & & Published \\
\hline Indonesia & W-00200702825 & 1-Mar-06 & & & Published \\
\hline $\begin{array}{l}\text { United States of } \\
\text { America }\end{array}$ & $13 / 335,238$ & 22-Dec-11 & & & Published \\
\hline ARIPO & AP/P/2007/004053 & 1-Mar-06 & & & Abandoned \\
\hline Australia & 2006218444 & 1-Mar-06 & & & Abandoned \\
\hline Barbados & & 1-Mar-06 & & & Abandoned \\
\hline Belize & & 1-Mar-06 & & & Abandoned \\
\hline
\end{tabular}




\begin{tabular}{|c|c|c|c|}
\hline Colombia & 07.086 .901 & 1-Mar-06 & Abandoned \\
\hline Cuba & $2007-0197$ & 1-Mar-06 & Abandoned \\
\hline $\begin{array}{l}\text { Dem. People's } \\
\text { Rep. of Korea }\end{array}$ & $07-2529$ & 1-Mar-06 & Abandoned \\
\hline Dominica & & 1-Mar-06 & Abandoned \\
\hline Israel & 184164 & 1-Mar-06 & Abandoned \\
\hline Madagascar & $2007 / 042$ & 1-Mar-06 & Abandoned \\
\hline Mongolia & & & Abandoned \\
\hline New Zealand & 590546 & 17-Jan-11 & Abandoned \\
\hline $\begin{array}{l}\text { Trinidad and } \\
\text { Tobago }\end{array}$ & TT/A/2008/00010 & 1-Mar-06 & Abandoned \\
\hline Vietnam & 1-2007-01999 & 1-Mar-06 & Abandoned \\
\hline PCT & PCT/US06/07568 & 1-Mar-06 & Expired \\
\hline
\end{tabular}

Table 12: Patent \& Patent Applications for module based oxy-combustions boiler

This new boiler design concept can be illustrated as:

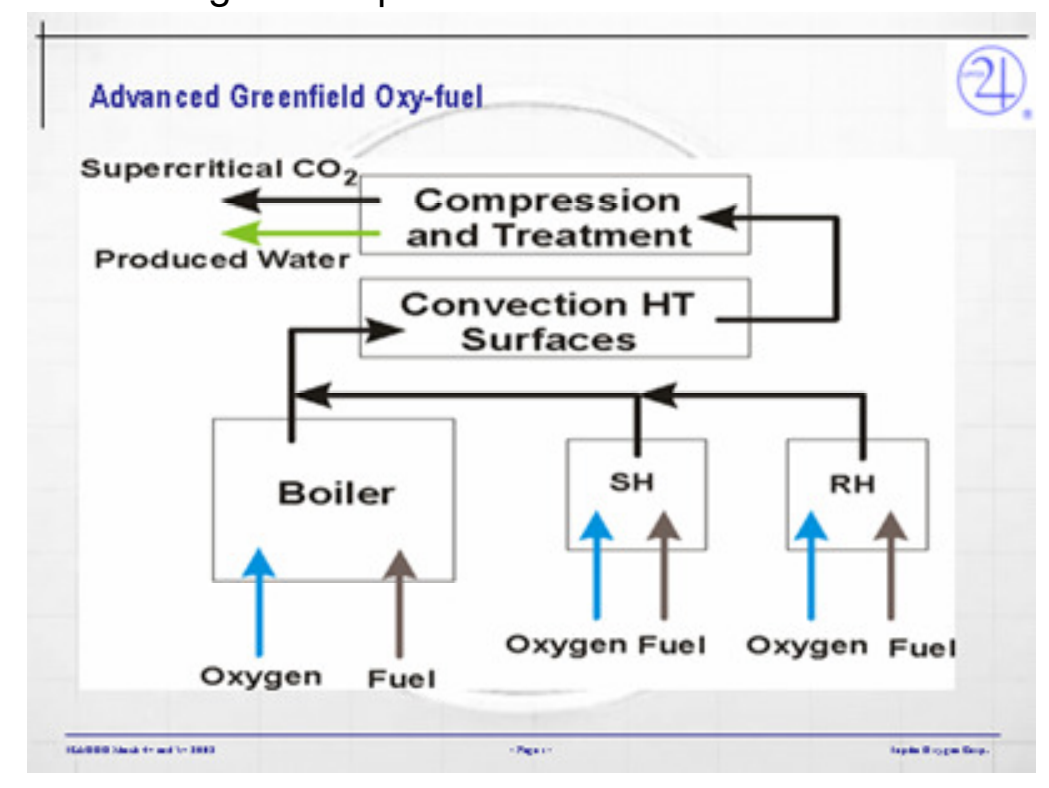

Figure 45: Advanced Greenfield Oxy-fuel System

NETL modeling and Jupiter projections indicate that the new boiler design will have $50 \%$ less heat transfer surface area with the same types of materials as air firing. This is estimated to result in a boiler installed cost savings exceeding $22 \%$. NETL modeling also showed a $10.4 \%$ fuel savings.

iii. Integrated Capture of Fossil Fuel Gas Pollutants Including $\mathrm{CO}_{2}$ with Energy Recovery

The subject matter of the patent and patent application for Integrated Capture of Fossil Fuel Gas Pollutants Including $\mathrm{CO}_{2}$ 
with Energy Recovery relates to a process for the removal of streams of various elements of pollution with energy recovery methods in order to remove more pollutants at less overall cost and with more fuel efficiency. In particular, the process is directed to reducing pollutants from flue gases from the combustion of fossil fuels before being exhausted into the atmosphere. The process removes nitrogen from air for combustion, separates the solid combustion products from the gases and vapors and can capture the entire vapor/gas stream for sequestration leaving near-zero emissions. Up to three captured material streams are produced by the process. The first stream is contaminant-laden water containing $\mathrm{SO}_{x}$, residual $\mathrm{NO}_{x}$ particulates and particulate bound $\mathrm{Hg}$ and other trace contaminants. The second stream is a low-volume flue gas stream containing $\mathrm{N}_{2}$ and $\mathrm{O}_{2}$. The final product stream is a mixture comprising predominantly $\mathrm{CO}_{2}$ with smaller amounts of $\mathrm{H}_{2} \mathrm{O}, \mathrm{Ar}, \mathrm{N}_{2}, \mathrm{O}_{2}, \mathrm{SO}_{x}, \mathrm{NO}_{x}, \mathrm{Hg}$ and other trace gases.

The flue gas generated by the combustion system is directed to a heat exchanger wherein the flue gas is cooled with a cooling fluid to a temperature where water and any condensable vapors present in the flue gas are condensed and removed as liquid condensate. The liquid condensate exits the heat exchanger either as a separate stream in the case of indirect heat exchange or along with the cooling fluid in the case of direct heat exchange. The process further includes filtering and treating the liquid stream (either condensate or condensate and cooling fluid) so that all pollutants are disposed of and pure water is released. The gas exiting the heat exchanger is compressed in at least one compressor into a $\mathrm{CO}_{2}$ stream suitable for disposal or other applications.

The patent and patent applications covering the Integrated Capture of Fossil Fuel Gas Pollutants Including $\mathrm{CO}_{2}$ with Energy Recovery are provided below.

\begin{tabular}{|l|l|l|l|l|l|}
\hline COUNTRY & APP. NO. & $\begin{array}{l}\text { FILING } \\
\text { DATE }\end{array}$ & PATENT NO. & $\begin{array}{l}\text { GRANT } \\
\text { DATE }\end{array}$ & STATUS \\
\hline $\begin{array}{l}\text { United States of } \\
\text { America }\end{array}$ & $11 / 753,393$ & 24-May-07 & $8,038,773$ & $18-$-Oct-11 & Issued \\
\hline PCT & PCT/US07/69670 & 24-May-07 & & & Abandoned \\
\hline
\end{tabular}

Table 13: Patent and Patent Applications covering the Integrated Capture of Fossil Fuel Gas Pollutants including $\mathrm{CO}_{2}$ with Energy Recovery 
10. Current State TRL (Technology Readiness Level) Justification

This project involved further development and testing of high flame temperature oxy-combustion in a steam generating boiler with IPR pollution removal and carbon capture. Specialized high flame temperature oxy-combustion burners for natural gas and coal were optimized. The test results were used to build a CFD model for scaling up high flame temperature oxy-combustion in larger, commercial steam generating boilers. Both high flame temperature oxy-combustion and IPR pollution removal and carbon capture are processes which can use commercialized equipment available from multiple vendors, except the specialized burners currently are available from a single manufacturer. Except for continued scale-up of the specialized burners, equipment currently is commercially available for the retrofit of large commercial boilers so scale-up of the technologies is feasible from an equipment standpoint. The development and testing provided further operationally experience with both high flame temperature oxy-combustion and IPR pollution removal and carbon capture, also making scale-up for a demonstration project feasible. In August, 2010, the JOC-NETL Project Update reported:

"High flame temperature oxy-combustion with IPR is ready for commencement of a demonstration project."

The additional development work through September, 2012 strengthened this readiness. As an additional measure, completed validation of the high flame temperature CFD modeling testing using high flame temperature measurements of taken during the firing of the oxycombustion system with the optimized pilot-scale coal burner. The CFD modeling validation for coal firing flame temperature was done showing that NETL flame temperature measurements in an area of the flame were consistent with Reaction Engineering modeling. With this validation, TRL 6 was reached. 


\section{Project conclusions}

The project accomplished its key goals as explained below.

Generated the necessary technical data required to demonstrate the technologies are viable for technical and economic scale-up and conform to DOE's Carbon Sequestration Program goals. The project demonstrated feasibility and effectiveness of the JOC high flame temperature oxycombustion process with Integrated Pollutant Removal process for CCS and CCUS. As previously stated in the JOC-NETL 8/2/10 Project Update:

- High flame temperature oxy-combustion with IPR is ready for commencement of a demonstration project.

- With these technologies total parasitic power requirements for both oxygen production and carbon capture currently are in the range of $20 \%$.

At the pilot test facility, the project team successful design, constructed, and operate a $5 \mathrm{MWe}$ equivalent test boiler facility and $20 \mathrm{KWe}$ equivalent IPR® facilities. The test facility was operated at steady state optimum oxy-coal combustion parametric studies were and performed.

Demonstrated that $\mathrm{CO}_{2}$ from the boiler/ IPR® can meets the specifications for deep saline aquifer sequestration and/or enhanced oil recovery but some distillation or other purification may be required.

Evaluated the retrofit impacts of the oxy-coal combustion and the IPR® process on power plant design issues.

The corrosion study results with 316 SS probes used under buffered IPR conditions showed relative corrosion resistances of 1-5 MPY (milli-inch per year) which is considered excellent. Therefore materials more expensive than 316 SS are not required for IPR equipment.

Inventions were created and patented that advance oxy-combustion and carbon capture. This included developing a new modular boiler design and a high flame temperature closed loop control approach.

Flame temperatures between 4930-6120F were achieved with high flame temperature oxy-natural gas combustion depending on whether additional re-circulated flue gases are added to balance the heat transfer. For high flame temperature oxy-coal combustion, flame temperatures in excess of $4500 \mathrm{~F}$ were achieved.

Current State TRL (Technology Readiness Level) Justification: Jupiter has completed validation of the testing of the high flame temperature oxycombustion system with the pilot-scale burner. The CFD modeling validation for coal firing flame temperature was done showing that NETL 
flame temperature measurements in an area of the flame were consistent with Reaction Engineering modeling. With this validation, TRL 6 was reached.

Economics were enhanced through savings on fuel usage and heat recovery. Water recovery and re-use can also enhance economics depending on specific project conditions.

Evaluated carbon capture retrofit capital costs to the Connesville \#5 power plant. In this evaluation corrected to 2012 dollars the JOC/NETL carbon capture equipment is shown to be $10 \%$ less than the capture system capital costs reported in NETL's Advancing Oxy-combustion Technology for Bituminous Coal Power Plants 2012 final report.

Both coal and natural gas were found to be fuels which can be used with high flame temperature oxy-combustion and IPR for CCS and CCUS, as well as other environmental improvement. Technical and economic strategies for use of coal and natural gas were outlined.

Two of the project's key technical and scientific advancements were:

- The spectral irradiance data acquired for the pilot scale high temperature oxy-coal flame is unique and can be used to inform future studies. Additionally, an improved technique was realized for flame temperature determination to account for the large particle temperature variations that occur in these flames as compared to aircoal flames.

- Test results with experimental evidence of the outcome of mercury in the IPR process. 
12. List of figures

Figure

Page

Figure 1: Oxy-combustion combustion and IPR ${ }^{(\circledast)}$ carbon capture process

schematic

Figure 2: B\&W test boiler at the JOC test facility

12

Figure 3: Maxon oxy-natural gas four burner assembly (view from inside 13

the boiler)

Figure 4: Typical Maxon oxy-coal burner configuration and mounting to the B\&W boiler.

Figure 5: IPR flow diagram

Figure 6: Installed IPR photographed

Figure 7: Flame Instrumentation located on east side of furnace 18

Figure 8: Composite spectraline data, NG test 23, IR port 2- flame 22

centerline, boiler duty $30 \mathrm{MMBtu} / \mathrm{hr}$, Equiv air molar volume $27.6 \%$.

Figure 9: Composite spectraline data, NG test 24, IR port 2 - flame

centerline, boiler duty $29 \mathrm{MMBtu} / \mathrm{hr}$, Equiv air molar volume $58.1 \%$.

Figure 10: Normalized heat flux for high flame temperature oxy-natural gas tests, boiler duty $\sim 30 \mathrm{MMBtu} / \mathrm{hr}$.

Figure 11: Ash LOI results for the modified first generation burner

Figure 12: Ash LOI results for the modified first generation burner

Figure 13: Ash LOI performance with oxygen swirl burner.

Figure 14: Ash LOI performance with oxygen swirl burner.

Figure 15: Reaction Engineering CFD model axial temperature profile area weighted and peak temperatures.

Figure 16: Reaction Engineering CFD model results for the 8/23/2012 test \#4. Radial temperature plot

Figure 17: CCD Spectrometer flame temperature determination at port 0 , August 23, 2012, JOC test \#4

Figure 18 (log scale) - SOx, NOx and $\mathrm{Hg}$ as they report to gas and water

at the outlets of consecutive process steps in IPR Note that the changes in solute concentration are for decreasing flow-rates of water from IPR.

Figure 19: Average concentration of elements in wastewater

30

31

32

33

41

Figure 20: $\mathrm{pH}$, Alkalinity variation of wastewater collected

52

Figure 21: Comparison of turbidity removal using $\mathrm{FeCl}_{3}$ and Alum on

54 wastewater samples

Figure 22: Comparison of turbidity removal using $\mathrm{FeCl}_{3}$ and Alum on wastewater samples

Figure 23: Normalized cations removal from flue gas condensed wastewater

Figure 24: Concentrations of anions present in water sample before and after water treatment

Figure 25: Comparison of turbidity removal using $\mathrm{FeCl}_{3}$ and

$\mathrm{FeCl}_{3}+$ Polymer

Figure 26: Comparison of turbidity removal using $\mathrm{FeCl}_{3}$ and

$\mathrm{FeCl}_{3}+$ Polymer 
Figure 27: Three Electrode Immersion Probe $\quad 61$

Figure 28: Three Electrode Flange Probe 61

Figure 29: IPR System Schematic with Probe Locations 62

Figure 30: Flat Immersion Probes 5 and $7 \quad 63$

Figure 31: Flange probe - electrodes surround the gas-stream 64

Figure 32: Corrosion rate determined from in-situ 316 SS probes 65

Figure 33: Corrosion rate determined from in-situ inconel probes 66

Figure 34: Mid-IR spectrum of oxy-natural gas and oxy-coal flames 68

Figure 35: Percentage of gases in combustion products comparing air 73 firing with oxy firing

Figure 36: A typical coal fired boiler showing the various heat transfer $\quad 74$ ones

Figure 37: Distribution of heat in the various zones 75

Figure 38: Block diagram of an air-fired coal system 78

Figure 39: Block diagram for an oxyfuel system with cold recirculation $\quad 78$

Figure 40: Hot recycle with cold motive gas $\quad 79$

Figure 41: Full hot recycle with hot recycled motive gas 80

Figure 42: Hot recycle only $\quad 80$

Figure 43: Advanced oxycoal system 81

Figure 44: Potential Advanced Greenfield oxyfuel system 82

Figure 45: Advanced Greenfield Oxy-fuel System 89 
13. List of tables

Table

Table 1: Flame temperature instruments and their capability

Page

Table 2: Flame temperature measurements for natural gas testing

Table 3: REI modeling cases for generation 2.1 burner

Table 4: Wavelengths utilized in the Flame Temperature Analysis

Table 5: Test results flame temperature measurement port 0

Table 6: Test results flame temperature measurement port 4

Table 7: Hammond Test Facility and ASPEN IPR-composition results compared

Table 8: Typical composition of coal analysis

Table 9: Typical oxides in fly ash

Table 10: Description of Probes and Test Conditions

60

Table 11: Patent \& Patent Applications filed for oxy-combustion and

62 IPR

Table 12: Patent \& Patent Applications for module based oxy-

86 combustions boiler

Table 13: Patent and Patent Applications covering the Integrated

89

Capture of Fossil Fuel Gas Pollutants including $\mathrm{CO}_{2}$ with Energy

Recovery 